\title{
INSTRUCTIONAL LEADERSHIP PERCEPTIONS AND PRACTICES OF ELEMENTARY SCHOOL LEADERS
}

A Capstone Project

$$
\text { Presented to }
$$

The Faculty of the Curry School of Education

University of Virginia

In Partial Fulfillment

of the Requirements for the Degree

Doctor of Education

$$
\text { by }
$$

Leslie Harris, B.S., M.Ed.

May 2014 
C Copyright by

\section{Leslie Harris}

All Rights Reserved

May 2014 


\section{Administration \& Supervision \\ Curry School of Education \\ University of Virginia \\ Charlottesville, Virginia}

\section{APPROVAL OF THE CAPSTONE PROJECT}

This capstone project, ("Instructional Leadership Perceptions and Practices of Elementary School Leaders"), has been approved by the Graduate Faculty of the Curry School of Education in partial fulfillment of the requirements for the degree of Doctor of Education.

Dr. Michelle Young

Dr. Sara Dexter

Dr. Daniel Player 
This work is dedicated to Edison Crews, my precious Papa. He was the smartest, gentlest, and most godly man I ever knew.

I know he'd be so proud of me if he were here today. 


\section{Acknowledgements}

To Mom and Dad, for being constant sources of love and support throughout my life and for always pushing me to excel at everything I do

To my chair and committee members, Michelle Young, Sara Dexter, and Dan Player, for your guidance throughout the capstone process

To my fellow cohort ladies, for your friendship and encouragement over the past three years of this journey

To Peter, Amanda, and Jonah, for making it possible for me to complete this program by graciously letting me spend all of my class weekends in your home 


\section{TABLE OF CONTENTS}

List of Tables......................................................................

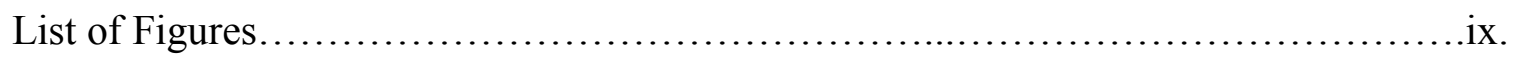

Executive Summary

Problem of Practice...............................................................

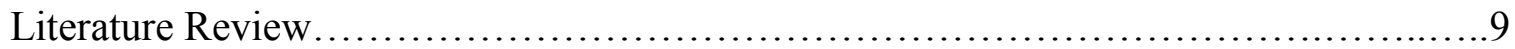

Conceptual Framework ......................................................... 31

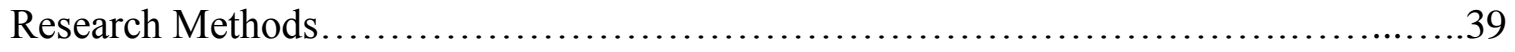

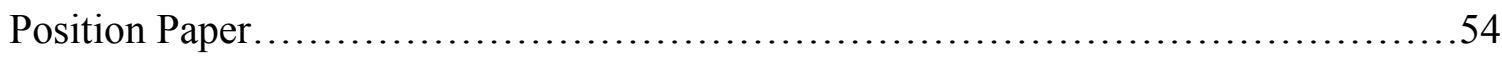

Action Communications....................................................... 117

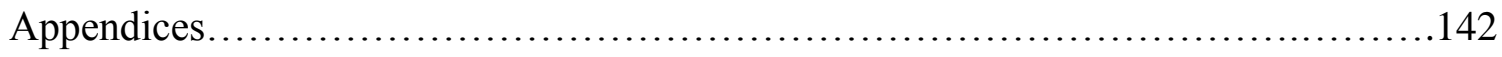

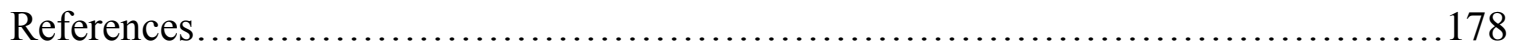




\section{LIST OF TABLES}

Table 1

Washington County SOL Test Performance in 2012-2013

Table 2

Defining Theories of Action: Espoused Theory and Theory-in-use

Table 3

Hypothetical Theories of Action for Instructional Leaders

Table 4

Research Sub Questions and Relevant Data Collected

Table 5

Overview of Research Methodology

Table 6

Phase I Data Analysis

Table 7

Survey Sample Size and Response Rates

Table 8

Phase II Data Analysis

Table 9

School A: Espoused Theory Compared to Research Base

Table 10

School B: Espoused Theory Compared to Research Base

Table 11

School C: Espoused Theory Compared to Research Base

Table 12

Espoused Theory Across School Settings

vii. 
Table 13

School A PIMRS Results: Defining the School Mission

Table 14

School A PIMRS Results: Managing the Instructional Program

Table 15

School A PIMRS Results: Developing the School Learning Climate

Table 16

School B PIMRS Results: Defining the School Mission

Table 17

School B PIMRS Results: Managing the Instructional Program

Table 18

School B PIMRS Results: Developing the School Learning Climate

Table 19

School C PIMRS Results: Defining the School Mission

Table 20

School C PIMRS Results: Managing the Instructional Program

Table 21

School C PIMRS Results: Developing the School Learning Climate

Table 22

PIMRS Domain Average Results: Defining the School Mission

Table 23

PIMRS Domain Average Results: Managing the Instructional Program

Table 24

PIMRS Domain Average Results: Developing the School Learning Climate

Table 25

Compilation of Phase I and Phase II Data

viii. 


\section{LIST OF FIGURES}

Figure 1

VDOE Rubric for Student Academic Progress Domain of Principal Evaluation (2012)

Figure 2

Models of Leadership Effects on Student Achievement

Figure 3

Bossert's (1982) Framework of Principal Instructional Management

Figure 4

The PIMRS Framework of Instructional Leadership

Figure 5

Processes of Theories-in-use (Argyris, Putnam \& McLain Smith, 1985)

Figure 6

Single and Double Loop Learning (Argyris, Putnam \& McLain Smith, 1985)

Figure 7

Themes of Principal Interview Protocol

Figure 8

School A: Congruence of Theories of Action

Figure 9

School B: Congruence of Theories of Action

Figure 10

School C: Congruence of Theories of Action 


\title{
Executive Summary
}

\author{
Dr. Michelle Young, Advisor
}

Principals across the state of Virginia will soon find themselves held accountable for the outcomes of their instructional leadership as part of a new principal evaluation system being implemented by the Virginia Department of Education during the 20132014 school year. To assess and increase principal and school district readiness for this new evaluation system in Washington County Schools*, this study investigated the nature of current instructional leadership practice among elementary school leaders. It examined the current beliefs and practices of instructional leadership among three elementary school principals, as well as the relationship between those beliefs and practices.

Qualitative and quantitative data was collected and analyzed to answer the central research question: What is the nature of principal instructional leadership in Washington County Schools? Principals shared information with the researcher about their instructional leadership beliefs (espoused theory) during private interviews. These data were analyzed and compared to data from multiple sources that resulted from the administration of the Principal Instructional Management Rating Scale (PIMRS), a 360 degree instrument that measures frequency of specific principal instructional leadership behaviors. The data generated by the PIMRS instrument provided information about principal implementation (theory-in-use) of instructional leadership from the perspective 
of the principal, teachers in the school, and the division Director of Elementary Education.

Data analysis showed many similarities among the three principals regarding their beliefs about instructional leadership. Themes that emerged from each data set were: knowledge, support, collaboration, progress monitoring, visibility, and impact. All of the principals focused most heavily on activities related to managing the school instructional program when sharing their beliefs about what constitutes instructional leadership. Research-based instructional leadership activities that were the least emphasized by the principals during qualitative data collection were as follows: protects instructional time, provides incentives for teachers, and provides incentives for learning.

In the second phase of data collection, the PIMRS instrument results shed light on principal implementation of instructional leadership. All three of the principals seemed to implement activities related to defining the school mission at a much higher rate than their espoused theory/beliefs indicated. While principal beliefs focused heavily on activities related to managing instruction in the school, teachers perceived that principals engaged in these activities - particularly those related to supervision and evaluation of instruction-less frequently than principals themselves believed that they did. In alignment with principal beliefs, which de-emphasized the role of activities related to developing the school learning climate, sources agreed that principals did not engage in these types of activities with as much frequency as other instructional leadership functions and tasks. Additionally, teachers and school leaders frequently disagreed about which specific principal instructional leadership behaviors would be most likely to 
improve teacher professional capacity, fulfilling the purpose of effective instructional leadership.

This study is based upon the notion that recognizing inconsistencies between beliefs and practices can lead to changes in behavior and heightened organizational outcomes (Argyris, 1987). Therefore, the recommendations and action communications suggested in this paper are interconnected. The "solution" to the identified problem of practice lies in increasing principal self-awareness regarding their beliefs (espoused theory) and practices (theory-in-use) and the relationship between the two. Argyris asserted that congruency between the two theories leads to the most effective designs of action (1980). This suggests that purposeful alignment of principal beliefs and implementation of instructional leadership could potentially be a lever for improving leadership practice and may assist principals in meeting the requirements set forth in the new principal evaluation system. 


\section{Problem of Practice}

\section{The Emerging Problem}

Accountability policy has significantly impacted expectations for student and educator performance. In a Virginia school district known in this paper as "Washington County," principals will soon be held accountable for student achievement by their state and school division. Importantly, this shift is occurring at a time when achievement trends in the division are declining or stagnant at best. This heightened focus on the measurable outcomes of the work of school administrators warrants further inquiry regarding the specific leadership practices educational researchers have linked to student achievement, and whether and how these practices are currently being implemented by school leaders in Washington County.

\section{Principal Accountability for Learning}

Beginning in 2013-2014, school principals across the Commonwealth of Virginia, including those in Washington County, will have $40 \%$ of their annual summative evaluations based on student academic progress. The changes to the evaluation system, codified in Section 22.1-294 of the Code of Virginia, reflect a dramatic shift in thinking about the relationship between leadership and student achievement. According to the VDOE's 2012 Guidelines for Uniform Performance Standards and Evaluation Criteria for Principals, "Using measures of student academic progress to inform principal evaluation only makes sense because the most direct measure of teacher quality appears to be student achievement, and principals have a direct impact on teacher quality" (p. 40). 
The assumptions driving the VDOE's new principal evaluation system appear to rest on two links: 1) the link between a principal's work and teacher quality, and 2) the link between teacher quality and student achievement. Over the past fifty years, a number of researchers have worked to clarify these relationships, with principal instructional leadership emerging as the most effective construct for modeling leadership impacts on student learning and achievement (e.g. Hallinger 2011; Leithwood, et al., 2006; Robinson et al., 2008; Quinn 2002; Blase \& Blase, 2000).

\section{Key Challenges Faced By Principals in Washington County}

In Washington County Schools, the responsibility of instructional leadership rests squarely on the shoulders of the school administration. The district's central organizational structure does not include any formal programs focused on the development of individual teacher professional capacity, such as instructional coaching or teacher leadership. Rather, the development of teacher professional capacity is a school level responsibility.

The 2013-2014 principal evaluation is being implemented in Washington County via a portfolio in which the principal is required to document whether and how goals for student academic progress were met throughout the year. This change has elicited general feelings of anxiety and discontent among division principals. In particular, principals have expressed two chief concerns. First, principals doubt their ability to meet student academic progress goals amid the current climate of decreased achievement. Second, principals are concerned about the lack of time they have available for instructional leadership tasks. With regard to the latter, one principal shared that in order to spend sufficient time in classrooms completing observations and conferencing with teachers, 
she took personal leave and hired a substitute principal to manage the office for the day (Personal communication, April 2013).

Time allocated to instructional leadership. The lack of time for instructional leadership seems to be a common problem among school administrators. Despite the demonstrable connections in research between instructional leadership, teacher quality, and student achievement, principals typically spend less than fifteen percent of their daily work time on instructional leadership tasks (Horng, Klasik, \& Loeb, 2010). Even principals that devoted above-average amounts of time to instructional leadership spent less than one-third of their day engaged in it (Goldring et al., 2007). If the findings of researchers like Goldring and Horng, et al. reflect the practice of most principals in Washington County Schools, then the amount of time spent engaged in instructional leadership is minimal.

\section{Increasing Rigor and Declining Achievement}

The latest revisions to the Virginia SOL and SOL tests reflect increasing academic rigor in all core subjects. In lieu of the purely multiple choice standardized tests that have been administered in Virginia since the 1990's, students are now required to demonstrate deeper levels of learning and understanding through open-ended, multiple response, or technology-enhanced test items (TEI). As of 2013-2014, increased rigor has been phased into all social studies, math, reading, writing, and science SOL tests administered to elementary students across Virginia. Subsequently, student achievement, as measured by end of course SOL tests, is declining or stagnant in reading and math in almost every elementary school in Washington County. Table 1, shown below, compares 
division averages and state averages for reading and math SOL tests administered during the 2012-2013 school year.

Table 1

Washington County SOL Test Performance in 2012-2013

$\begin{array}{ccc}\text { SOL Test } & \begin{array}{c}\text { State } \\ \text { Average } \\ 72\end{array} & \begin{array}{c}\text { Division } \\ \text { Average } \\ 69\end{array} \\ 3^{\text {rd }} \text { Grade Reading } & 70 & 70 \\ 4^{\text {th }} \text { Grade Reading } & 73 & 66 \\ 5^{\text {th }} \text { Grade Reading } & 71 & 63 \\ 5^{\text {th }} \text { Grade Writing } & 65 & 69 \\ 3^{\text {rd }} \text { Grade Math } & 74 & 78 \\ 4^{\text {th }} \text { Grade Math } & 69 & 67 \\ 5^{\text {th }} \text { Grade Math } & \end{array}$

With no state averages above 74 percent, these data indicate that poor performance on end-of-course SOL tests is a problem all across Virginia that can likely be attributed to the new and more rigorous state tests. However, in most cases, Washington County student achievement registers below these already low state averages, and these statistics do not bode well for the upcoming evaluations of PCS elementary school leaders.

\section{Overview of the Problem in Context}

Given new state policies regulating principal evaluation, Virginia school leaders will soon be held accountable by the state and school division for their role in student learning. It remains to be seen what the large-scale impact of this policy change will be. Regardless, for Washington County school leaders, the changes in policy raise several 
important questions about their instructional leadership practices as well as their perceptions about their instructional leadership responsibilities and their impact on teacher quality and student achievement. For example, how do principals understand their instructional leadership responsibilities? How do they allocate their time and effort, and do they engage in leadership practices that impact teacher quality, and thereby, student achievement?

\section{Purpose of Study}

In this capstone project, I explored the nature of principal instructional leadership in Washington County in order to: 1) ascertain principal readiness for the implementation of the new evaluation system, and 2) to use that assessment of readiness to assist individual principals and district leaders to increase readiness. Gaining a better sense of leaders' beliefs about instructional leadership, to what degree this responsibility is emphasized in their work, and how their instructional leadership is practiced and perceived by a variety of stakeholders provides insight that can support leaders' professional learning.

Additionally, I was interested in understanding the consistency between leadership beliefs and leadership practice around instructional leadership. Specifically, the juxtaposition of limited time allocated towards instructional leadership despite its acknowledged importance in the field suggests potential inconsistencies between principal espoused theory and theories-in-use related to instructional leadership (Argyris \& Schön, 1974). Argyris asserts that congruency between the two theories leads to the most effective designs of action (1980). This suggests that purposeful alignment of 
principal beliefs (espoused theory) and implementation (theories-in-use) of instructional leadership could potentially be a lever for improving practice.

\section{Research Questions}

In an effort to better understand instructional leadership in Washington County, I proposed the following central research question: What is the nature of instructional leadership in Washington County elementary schools? To guide my work on the central question, I asked several sub questions.

- Sub Question 1: How do Washington County elementary principals define instructional leadership, and what practices do they associate with it?

- Sub Question 2: How do various stakeholders (the principal, teachers, and direct supervisor) perceive the principal's implementation of instructional leadership in the school?

- Sub Question 3: What is the relationship between principal espoused theory (beliefs) and theories-in-use (practices) of instructional leadership?

\section{Significance of Study and Delimitations}

Regardless of the policy context, principal instructional leadership remains an important issue to explore. The Interstate School Leaders Licensure Consortium (ISLLC) Standards, which have been adopted in Virginia as a framework for effective school leadership, all relate in some way to instructional leadership tasks or their intended outcomes. Instructional leadership has been clearly linked by researchers to enhanced teacher quality and student achievement. Principals that are not allocating efforts to 
research-based instructional leadership activities may not fulfill the requirements of their evaluation, but more importantly, they will not be meaningfully engaging in work that educational researchers suggest can improve the quality of teaching and learning in their schools. Therefore, research-based instructional leadership is a key component of any principal's job description, and its effective implementation is necessary for achieving school performance goals.

In addition to providing useful information about the instructional leadership of Washington County school leaders, this study contributed to the growing understanding of school leaders' perceptions of instructional leadership and the degree to which those perceptions align with current instructional leadership practices. Furthermore, the inclusion of additional stakeholder groups, such as teachers, offered an important and under-examined set of perspectives to the instructional leadership literature. Finally, participation in a project of this kind should have encouraged reflection on and increased understanding of the practice of instructional leadership among school leaders and their stakeholder communities.

Three elementary schools were selected for participation based on declining student achievement trends, high poverty rates, Title I status, and leadership by the same principal for the past five or more years. The findings reported in this study are representative of the individual participants in the specified context and are not intended for use in making broader generalizations about elementary principal instructional leadership in other settings. 


\section{Summary}

This capstone project explored the instructional leadership work of elementary principals in Washington County Schools. Specifically, I examined their current perceptions of instructional leadership, the leadership practices they associate with instructional leadership, and how they allocate their time to such efforts. I assessed principal practices of instructional leadership from multiple perspectives, including those of the principals, teachers, and division Director of Elementary Education. Finally, I determined whether principal perceptions and practices of instructional leadership are aligned with research-based definitions of instructional leadership, and whether principal espoused theory and theories-in-use of instructional leadership are congruent.

In the next section, I turned to the literature to further examine the link between principal leadership and student learning, principal time allocation towards instructional leadership, teacher perceptions of the benefits of instructional leadership, and the specific instructional leadership behaviors that are associated with enhanced teacher quality and student achievement. Subsequently, I explained the theoretical lens I selected for examining principal perceptions and practices of instructional leadership and the interaction between the two. I next described the research methods that were used to carry out this study. In later sections of this paper, I presented relevant findings and recommended solutions to the problem of practice, including appropriate action communications. 


\section{Literature Review}

Prior to the 2013-2014 academic year, the Virginia Department of Education (VDOE) standards for principal summative evaluation included the following six domains, weighted equally:

- Instructional Leadership

- School Climate

- Human Resources Management

- Organizational Management

- Communication and Community Relations

- Professionalism

The VDOE's 2012 Guidelines for Uniform Performance Standards and Evaluation Criteria for Principals include a seventh standard: Student Academic Progress. This standard will be included in all Virginia principals' summative evaluations in 2013-2014, and it will be weighted at $40 \%$. Each of the previous standards will remain a part of the evaluation, weighted at $10 \%$ each, to comprise the remaining $60 \%$ of the total, summative score. The rubric created by the VDOE (2012) for use by Virginia school divisions in evaluating a principal's performance in the Student Academic Progress domain of the 2013-2014 evaluation system is pictured as Figure 1 on the following page. 


\begin{tabular}{|l|l|l|l|}
\hline $\begin{array}{c}\text { Exemplary } \\
\text { In addition to } \\
\text { meeting the } \\
\text { requirements for } \\
\text { Proficient... }\end{array}$ & $\begin{array}{c}\text { Proficient } \\
\text { Proficient is the } \\
\text { expected level of } \\
\text { performance. }\end{array}$ & $\begin{array}{c}\text { Developing/ } \\
\text { Needs } \\
\text { Improvement }\end{array}$ & Unacceptable \\
\hline $\begin{array}{l}\text { In addition to } \\
\text { meeting the } \\
\text { standard, the } \\
\text { principal's } \\
\text { leadership results in } \\
\text { a high level of } \\
\text { student academic } \\
\text { progress with all } \\
\text { populations of } \\
\text { learners. }\end{array}$ & $\begin{array}{l}\text { The principal's } \\
\text { leadership results } \\
\text { in acceptable, } \\
\text { measurable, } \\
\text { student academic } \\
\text { progress based on } \\
\text { established } \\
\text { standards. }\end{array}$ & $\begin{array}{l}\text { The principal's } \\
\text { leadership results in } \\
\text { student academic } \\
\text { progress that } \\
\text { inconsistently meets } \\
\text { the established } \\
\text { standard. }\end{array}$ & $\begin{array}{l}\text { The principal's } \\
\text { leadership } \\
\text { consistently results } \\
\text { in inadequate } \\
\text { student academic } \\
\text { progress. }\end{array}$ \\
\hline
\end{tabular}

Figure 1

VDOE Rubric for Student Academic Progress Domain of Principal Evaluation (2012)

Principals will be rated at one of four levels, from unacceptable to exemplary, based upon whether student academic progress was achieved during the school year. This rubric and its categorical indicators are broad and general. Researchers agree that relevant performance feedback is essential for learning (Frase, 2001; Hattie \& Timperley, 2007; Vollmeyer \& Rheinberg, 2005). However, the descriptions in the evaluation rubric above fail to provide specific feedback for principals who are not performing at the highest levels regarding how they can improve. Principals who are highly rated may be unsure which facets of their work contributed to their success in impacting student achievement. Conversely, principals who are poorly rated will likely be left wondering precisely how their work as a school leader can be improved and altered to achieve their goals for student academic progress.

This project is focused on instructional leadership and how principals perceive and engage in it as a vehicle for enhancing teacher quality and thereby, student 
achievement. To situate this issue in education research, I examined relevant research that links principal behaviors to student outcomes through instructional leadership. I explored the shifting definitions of instructional leadership over time, aspects of the instructional leadership experience for principals and teachers, as well as the continued relevancy of instructional leadership tasks for contemporary school leaders. I have included sections on the following issues below:

- The role of the principal in impacting student achievement

- Models of principal impact on student outcomes

- Early definitions of instructional leadership

- Principal time allocation for instructional leadership

- Teachers and the instructional leadership experience

- The PIMRS framework for instructional leadership

- Operationalizing the PIMRS dimensions \& their continued relevancy

\section{Role of the Principal in Impacting Student Achievement}

Over 50 years of research seeks to clarify the relationship between the principal's work and student achievement (e.g. Bell, Bolam, \& Cubillo, 2003; Bridges, 1982; Gross \& Herriot, 1965; Witziers, Bosker, \& Kruger, 2003). The following models of leadership, all believed to impact student learning, have been a focus of education research for many years, and have sustained notoriety over time:

○ Instructional leadership (Bossert, Dwyer, Rowan \& Lee, 1982; Hallinger \& Murphy, 1985a; Robinson et al., 2008)

○ Transformational and transactional leadership (Burns, 1978; Leithwood \& Jantzi, 2000; Bass \& Riggio, 2006) 
○ Strategic leadership (Rowe, 2001; Davies, Ellison \& Bowring-Carr, 2005; Eacott, 2010)

○ Teacher leadership (Barth, 2001; Lambert, 2002; York-Barr \& Duke, 2004)

○ Collaborative leadership (Kanter, 1994; Chrislip, 2002; Hallinger \& Heck, 2010)

○ Distributed leadership (Pearce \& Sims, 2001; Spillane, 2006; Bergman, Rentsch, Small, Davenport, \& Bergman, 2012)

Despite the waxing and waning popularity of each of these models, instructional leadership is shown to have more impact than competing models of leadership on student achievement (Hallinger, 2011; Leithwood et al., 2006, Robinson et al., 2008; Quinn 2002; Blase \& Blase, 2000). "The more leaders focus their relationships, their work, and their learning on the core business of teaching and learning, the greater their influence on student outcomes" (Robinson et al., 2008, p. 2). In alignment with Robinson's assertion, Leithwood and colleagues (2011) recommended that policymakers focus on instructional leadership as a primary lever for school improvement.

\section{Models of Principal Impact on Student Outcomes}

The key assumption of the new principal evaluation system emphasizes the link between the principal's work and teacher quality, and teacher quality and student achievement (VDOE, 2012). In this way, principals are being held accountable for the indirect outcome of their work (student achievement) instead of the work itself (impacting teacher quality). How, then, does the work of the principal result in changes in student achievement? The three models shown in the figure below illustrate several ways 
in which principals might impact student achievement through direct, mediated, or reciprocal effects (Pitner 1988, Hallinger \& Heck 1996).

Model A: Direct-effects Model

Principal Leadership

Student Achievement

Model A-1 Direct-effects with Antecedent Effects

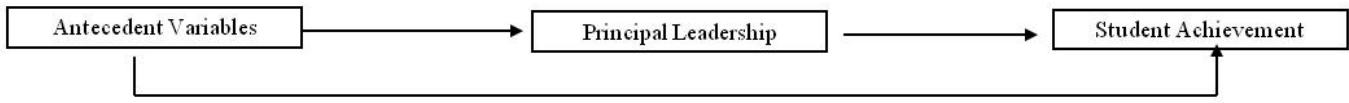

Model B: Mediated-effects

Principal Leadership $\longrightarrow$ Intervening Variables $\rightarrow$ Student Achievement

Model B: Mediated-effects with Antecedent Effects (B-1)

Antecedent Variables

$\longrightarrow$ Principal Leadership

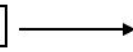

Intervening Variables

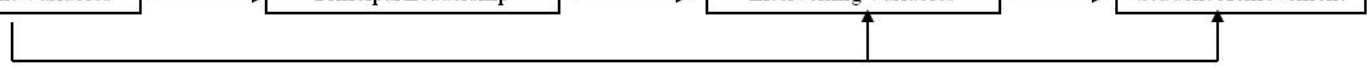

Student Achievement

Model C: Reciprocal-effects Model

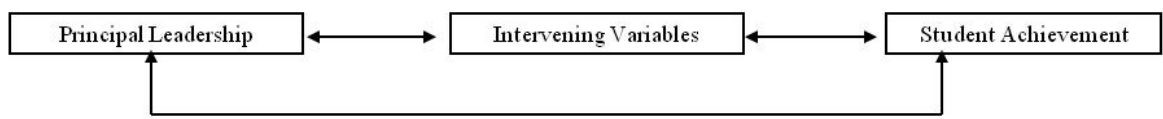

Figure 2

Models of Leadership Effects on Student Achievement

The VDOE's (2012) new principal evaluation system appears to be based on Model B:

Mediated Effects, with teacher quality as the intervening variable between the principals' leadership and student achievement.

A more detailed framework developed by Bossert et al. (1982) illustrates the impact of principals on student outcomes and remains influential in the field of instructional leadership. Pictured below (Figure 3), the framework closely mirrors the Mediated-effects with Antecedent Effects model (B-1) from the Figure 2. Bossert's 
(1982) framework asserts that principal instructional management is shaped by personal, district, and community characteristics. Shaped by these antecedent variables, the principal's instructional management then impacts school climate and the organization of instruction that takes place in the school (intervening variables). All of these factors, in turn, lead to student outcomes.

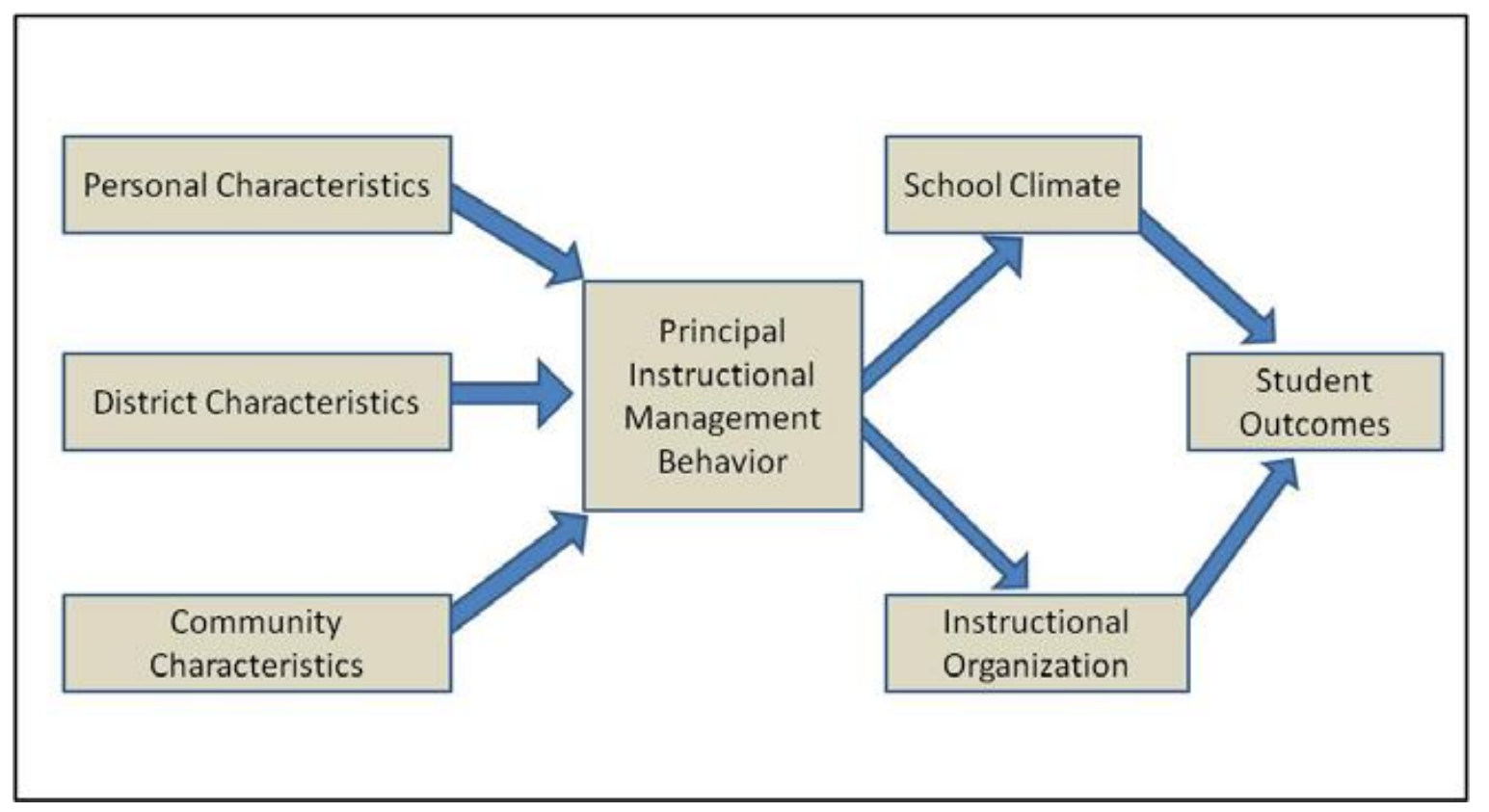

Figure 3

Bossert's (1982) Framework of Principal Instructional Management

Clearly, there is no single blueprint for determining the precise relationship between the leadership and work of the principal and student achievement in a school. However, the researchers cited above seem to agree that principal instructional leadership plays a critical role in impacting student outcomes. How is instructional leadership defined and practiced among school leaders? 


\section{Early Definitions of Instructional Leadership}

Some ambiguity exists in early definitions of "strong instructional leadership from the principal" (Weber 1971; Cuban, 1984; Murphy, Hallinger \& Mitman, 1983). Instructional leadership began as a practice-based construct and has been prominent for the past fifty years, beginning with Lipham's assertion that good principals make good schools (1961). What were these "good principals" doing to positively impact their schools?

Dwyer (1984) claimed that, there was "no single image or simple formula for successful instructional leadership" (p. 33). However, early researchers of the leadership style found a common thread: "strong instructional leadership from the principal" was an identifying factor in effective schools (Lezotte, Edmonds, and Ratner, 1975; Edmonds, 1979; Purkey \& Smith, 1983). Instructional leadership was embodied in principals who had "turned their schools around" and were directive and assertive (Bamburg \& Andrews, 1990; Edmonds, 1979). The "principal has to be the person the instructional personnel look to for the instructional leadership in the system. If they do not, the implications for the school are considerably negative" (Edmonds 1981, p. 26). Clearly, early conceptualizations of instructional leadership included the ability of practitioners to have a major impact on school and student outcomes.

In addition to the expected school outcomes of instructional leadership, early researchers agreed that high expectations, focus, and vision are hallmarks of the style. Instructional leaders set high expectations for students and teachers and were viewed by their colleagues as the small minority of school administrators that were able to resist the pressures that pushed them away from the work of teaching and learning (Mortimore, 
1993; Glasman, 1984). Much like transformational leaders, instructional leaders are focused and set a clear vision for teaching and learning in the school with the goal of improving student achievement (Bamburg \& Andrews, 1990; Goldring \& Pasternak, 1994). This singular focus extends beyond instructional tasks and includes day-to-day activities, as instructional leaders manage all facets of the school in alignment with the academic mission (Cohen \& Miller, 1980; Dwyer, 1986; Heck, 1992). Effective instructional leaders are entrenched in the work of teaching and learning, and they not afraid to work closely with teachers to improve their skills and professional capacity (Cuban, 1984; Edmonds, 1979). Foriska (1994) discussed instructional leadership as "critical to the development and maintenance of an effective school" (p. 33).

In the mid-1990's, instructional leadership was the most-researched construct of school leadership in North America, and it has become a more global concept studied in many other countries as well (Hallinger \& Heck, 1998). Recent legislation focused on increasing accountability for teachers, principals, and school divisions, such as No Child Left Behind and the Race to the Top, brings contemporary focus and saliency to the study of instructional leadership (Neumerski, 2012). Recommendations for policy and practice in the field frequently emphasize building principal instructional leadership capacity in the face of increasingly challenging curricula and heightened accountability for student learning (Elmore, 2004; Nelson \& Sassi, 2005).

Researchers and proponents of instructional leadership believe that education reform requires skillful instructional leadership (Fullan, 2006; Hall \& Hord, 2002). This assertion raises questions about precisely what, amid decades of research studying 
instructionally-effective principals and schools, skillful instructional leadership really is and how school leaders can effectively practice it.

\section{Principal Time Allocation for Instructional Leadership}

The ability to devote sufficient time to implementing skillful instructional leadership will become increasingly critical in the upcoming year, as the outcomes of instructional leadership will be weighted at $40 \%$ by the VDOE (2012). Research clearly demonstrates that principals are confronted by many factors, such as student issues, paperwork, and meetings, which detract time from instructional leadership (e.g., Barth, 1990; Horng, Klasik, \& Loeb, 2010; Marshall, 1996; Goldring et al., 2012). As mentioned previously, principals often allocate less than $15 \%$-- and at most, $33 \%$-- of their time to instructional leadership tasks in a given day (Horng, Klasik, \& Loeb, 2010; Goldring et al., 2007).

Regardless of the amount of time spent engaged in instructional leadership, the illusory heroism of effective instructional leaders has been found to create feelings of role inadequacy on the part of their colleagues - principals who aren't able to fit as many of these activities into their daily schedules (Barth, 1986; Donaldson 2001; Marshall, 1996). Perhaps, however, the "heroic" principals who practice effective instructional leadership are not devoting the majority of their time towards it, but are instead utilizing their limited time in ways that they believe have maximum impact for teacher quality and student achievement. Indeed, which instructional leadership experiences do teachers perceive are most beneficial to enhancing their professional capacity? 


\section{Teachers and the Instructional Leadership Experience}

A review of literature related to teacher perceptions of the instructional leadership experience leaves much to be desired. Surprisingly few studies have identified and analyzed leader/instructor behaviors from the viewpoint of the instructed adult. Existing research on the relationship between the leader and the led focuses on the dynamic between classroom teachers and their students (e.g., Lowenberg, 1979; Collins \& Stevens, 1983). Blase and Blase (2000) conducted one of the first comprehensive empirical studies examining teacher perspectives on principal instructional leadership characteristics and their impact on teachers. According to Blase and Blase (2000) teachers reported that "talking with teachers to promote reflection and promoting professional growth are the two major dimensions of effective instructional leadership" (p. 137). Promoting reflection included five identified strategies, listed below:

(1) making suggestions,

(2) giving feedback,

(3) modeling,

(4) using inquiry and soliciting advice and opinions, and

(5) giving praise (Blasé \& Blasé, 2000, p. 133).

Promoting professional growth was defined by six strategies:

(1) emphasizing the study of teaching and learning;

(2) supporting collaboration efforts among educators;

(3) developing coaching relationships among educators;

(4) encouraging and supporting redesign of programs;

(5) applying the principles of adult learning, growth, and development to all phases of staff development; and

(6) implementing action research to inform instructional decision making (Blasé \& Blasé, 2000, p. 135).

Interestingly, a more recent study by Patrick, Scrase, Ahmed, and Tombs (2009) conducted in a military context found five categories of effective instructor behaviors that mirror the findings of Blasé and Blasé (2000). The effective leadership behaviors among 
leaders of the United Kingdom's armed forces included "showing and demonstrating; encouraging behaviours, using instructional strategies, feedback, practice and adapting; and helping" (Patrick et al., 2009, p. 503). Similarities between their work and that of Blasé and Blasé (2000) included the following specific strategies:

making suggestions, giving feedback, modeling, and praise (four strategies from a dimension they labeled 'promoting reflection' in those to be instructed); and, listening, sharing experiences, and using examples and demonstrations (associated with 'making suggestions') (Patrick et al., 2009, p. 503).

Clearly, the limited research that exists emphasizes the importance of collegial relationships between school leaders and teachers, rooted in authentic communication, as a foundation for effective instructional leadership.

The scarcity of research related to the principal's instructional leadership behaviors from the teacher perspective indicates a gap in literature that is addressed in the second research questions of the present study. However, it is important to note that contemporary research does give more attention to the participative role of teachers in instructional leadership (e.g., Pearce \& Sims, 2001; Spillane, 2006; Bergman, et al., 2012). Leadership for learning and distributed leadership are two paradigms closely related to instructional leadership that emphasize the role of individual teachers. In these models, principals share power and distribute responsibilities for instructional improvement among teachers. However, creating a school culture that supports teacher leadership may require a great deal of restructuring, as most teachers spend $80-90 \%$ of their work time in direct contact with their students (Hoerr, 1996).

In Washington County Schools, there are few formal teacher leadership structures, and those that currently exist are primarily centered upon information-sharing between the central office and school buildings. Particularly in elementary schools, there 
are few informal leadership opportunities as well, possibly due to their relatively small size and the self-contained, isolated nature of the typical elementary classroom. While teachers may informally share responsibility for instructional leadership, the current policy context lays the whole of accountability for instructional leadership on the shoulders of the principal. Additionally, in models of shared leadership, the responsibility for mobilizing teachers and other staff members to take on instructional leadership tasks rests with the school leader. Therefore, while leadership for learning and distributed leadership are emerging models that also merit further examination by researchers, instructional leadership by the principal is the singular focus of the proposed study. In the next section of this paper, I will operationalize research-based instructional leadership and situate it in contemporary research.

\section{The PIMRS Framework for Instructional Leadership}

The broad and sometimes ambiguous definitions of instructional leadership described above made it difficult to pinpoint and study the precise behaviors associated with effective instructional leadership. The Principal Instructional Management Rating Scale (PIMRS) was the first validated tool that was created by education researchers in order to assess specific principal instructional leadership behaviors (Hallinger \& Murphy, 1985). The PIMRS instrument, created in the 1980 's and updated as recently as 2013 , is based on Hallinger and Murphy's (1985) extensive, research-based framework for effective instructional leadership. The framework is presented on the following page: 


\section{PIMRS Framework}
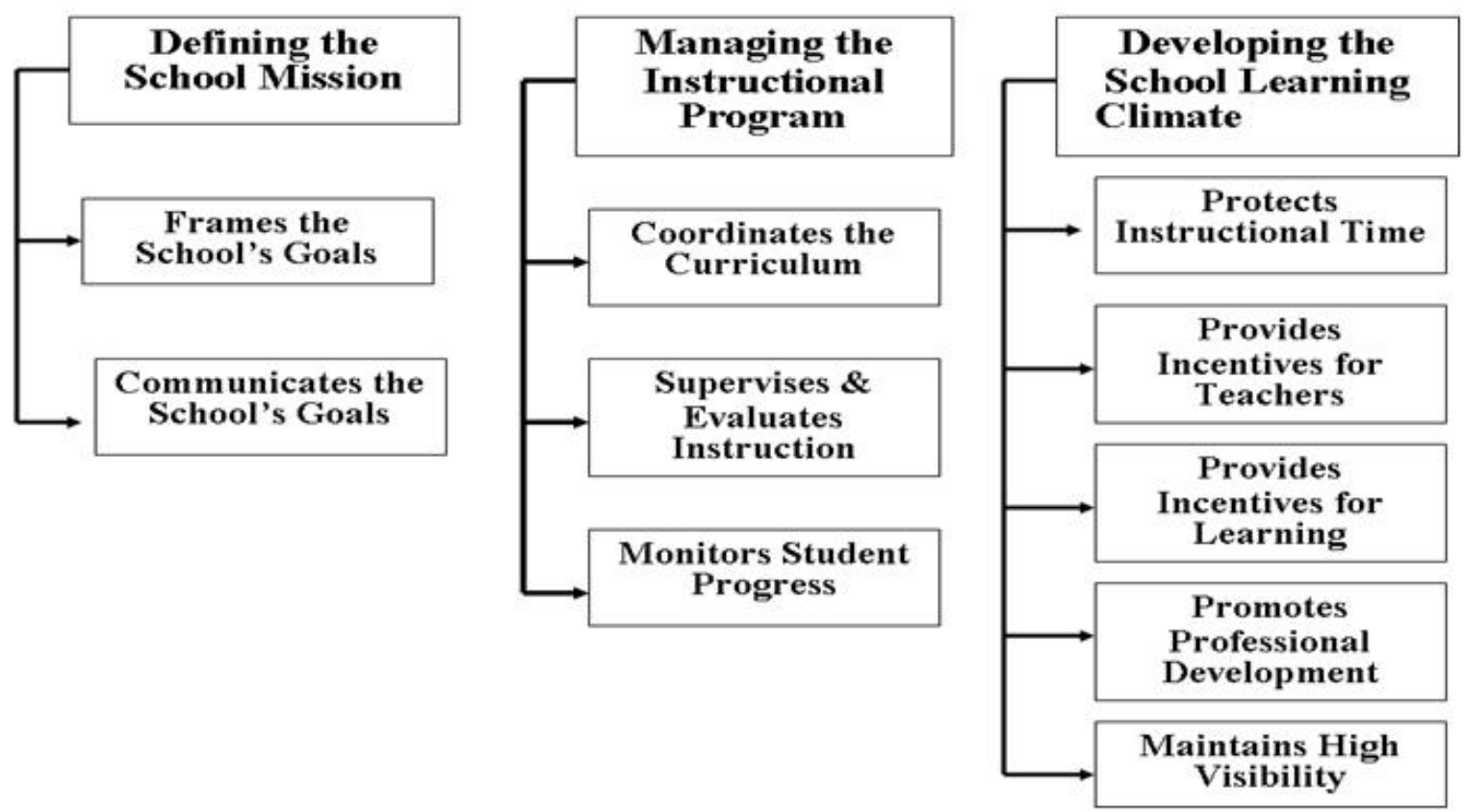

Figure 4

The PIMRS Framework of Instructional Leadership

The PIMRS framework includes three primary domains: defining the school mission, managing the instructional program, and developing the school learning climate. There are multiple functions within each domain, and a total of ten. These ten functions are seen as the primary responsibilities of instructional leaders, gleaned from research studying instructionally effective schools and the principal's job function and role as an instructional manager in those schools (Hallinger \& Murphy, 1985). Although this framework was initially created in the 1980 's, contemporary education research continues to support the importance and validity of the PIMRS domains and associated functions in implementing effective instructional leadership. In the next section of this 
literature review, I defined each of Hallinger's domains and functions of instructional leadership and establish their continued relevancy in school leadership today.

\section{Operationalizing the PIMRS Dimensions \& Continued Relevancy}

Defining the school mission. The first dimension of instructional leadership is concerned with "the principal's role in working with staff to ensure that the school has a clear mission and that the mission is focused on academic progress of its students" (Hallinger 2013, p. 14). An inspiring, desirable vision that is shared by school stakeholders is critical to organizational success (Kantabutra \& Avery, 2005). Effective organizational visions are inspirational, accepted by all stakeholder, and easily integrated into practice (Sims \& Lorenzi, 1992). Kurland, Peretz, and Hertz-Lazarowitz (2010) found that collective focus on a school vision creates a sense of purpose and binds stakeholders together, facilitating higher levels of organizational learning and growth. Once established, the school's mission should serve as a mental model for understanding the organization's purpose and guiding its members' actions (Mumford \& Strange, 2005). An effective instructional leader works to create and articulate a shared vision, mission, and goals that are clear and easy for staff members to incorporate into their daily practice (Hallinger 2013).

Frames the school's goals. This function of defining the school mission denotes the principal's role in determining the area of focus for school goals and the needed resources (Hallinger, 2013). Based on the school's mission for improving student achievement, effective instructional leaders work with staff to frame a manageable number of data-driven goals with clearly outlined responsibilities and measurable outcomes (e.g., Brookover, Schweitzer, Schneider, Beady, Flood, \& Wisenbaker, 1982; 
Edmonds, 1979; Venezky \& Winfield, 1979; Clark, 1980). Principals that use data to frame the school's instructional needs and goals are able to make informed decisions that positively impact student learning (Boudett \& Steele, 2007). School improvement planners should also frame goals around the needs of both low and high achievers to balance equity and excellence (Duke, 2013). Kotter (1999) defines effective leadership as the ability to develop a relevant vision and corresponding goals, align people to carry them out, and empower them to persevere against the odds.

Communicates the school's goals. Principals can communicate school goals to stakeholders in a variety of ways. Hallinger (2013) asserts that school goals should be discussed regularly by the principal and staff members, "especially in the context of instructional, curricular, and budgetary decisions" (p. 14). Instructional leaders that are communicators convey the essential beliefs to staff that the school can enhance student success (Smith \& Andrews, 1989). Research demonstrates the importance of communicating and articulating school goals regularly through both formal and informal means, such as print materials, school assemblies, and educative conferences/conversations (Brookover \& Lezotte, 1979). Communicating frequently about the school vision promotes change in stakeholder beliefs and attitudes (Levin, 2000). Frequent goal communication can lead to heightened individual employee buy-in, and Klein et al. (1999) found that employee goal commitment had strong, positive effects on job performance.

Managing the instructional program. The second domain of the PIMRS framework is focused upon the principal's role in coordinating the school's curricular program. Effective instructional leaders are "deeply engaged in stimulating, supervising 
and monitoring teaching and learning in the school" (Hallinger, 2013, p. 15). Principals should have expertise in teaching and learning and should be entrenched in the work of optimizing the school's instructional program to improve student achievement (e.g., Dwyer, 1986; Marshall, 1996). Principal instructional management is closely tied to student outcomes (Bossert et al., 1982). "Schools are only as good as the quality of faculty, the professional development that supports their learning, and the faculty's capacity to work together to improve instruction” (Bryk, 2010, p. 24). Priem and Rosenstein (2000) suggest that effective leaders align people, support systems, and job design in accordance with the organization's vision to boost performance.

Coordinates the curriculum. Curricular alignment is associated with effective instructional leadership; this occurs when school and classroom learning objectives, curriculum tools, and assessments are directly connected (Hallinger, 2013). Cross-grade level curriculum alignment is also a characteristic of instructionally sound schools, particularly when teacher groups are given the opportunity to collaborate regarding instructional decisions (e.g., Clark, 1980; Cohen \& Miller, 1981; Cooley \& Leinhardt, 1980; Wellisch, MacQueen, Carriere, \& Duck, 1978). Proper curriculum alignment ensures that all students have the opportunity to learn the material on which they will be assessed at the classroom and state level (Martone \& Sireci, 2009). Schools improve student learning when a "coherent instructional guidance system" supports teachers in collectively aligning student learning objectives with assessments, materials, and resources (Bryk, 2010). When administrators and teachers are both actively involved in curriculum alignment processes, significantly positive change can occur (McGehee \& Griffith, 2001). 
Supervises and evaluates instruction. Hallinger (2013) asserts that the principal's primary duty in supervision and evaluation of instruction is to, "ensure that the goals of the school are being translated into practice at the classroom level” (p. 15). In addition to formal teacher evaluation, non-evaluative classroom visits and subsequent instructional support provided to teachers play an important role in the supervision process (e.g., Levine, 1982; Lipham, 1981). "Instructional leadership requires the principal to work closely with teachers to practice the skills they need to improve their work" (BambrickSantoyo, 2012).

Principals are not expected to be experts in every curricular area, but they are expected to supervise and support teachers as they provide instructional opportunities to students, and principal content knowledge does play a role in teacher perception of the usefulness of feedback (Marks \& Printy, 2003; Tuytens \& Devos, 2011). Leaders implementing instructional supervision create an atmosphere of frequent feedback and reflection on performance, and this is an attribute of many high-performing schools (Runhaar, Sanders, \& Yang, 2010; Robinson, Lloyd, \& Rowe, 2008).

Principal supervision of instruction can lead teachers to alter their teaching practices, thereby enhancing student learning and achievement (Supovitz, Sirinides, \& May, 2009). Formative and summative teacher evaluation can be a vehicle for improving the quality of teaching and learning in the school (Timperley \& Robinson, 1997). Teacher evaluation that provides meaningful, relevant feedback leads to heightened job performance and is key to teacher professional learning (Stronge \& Tucker, 2003; Tang \& Chow, 2007). 
Monitors student progress. Data-driven decision-making is a key component of effective instructional leadership; Hallinger (2013) recommends that data should be collected and analyzed to, “diagnose programmatic and student weaknesses, to evaluate the results of changes in the school's instructional program, and to help in making classroom assignment" (p. 16). The principal should work alongside teachers and take an active role in discussing and disaggregating relevant data (e.g., Stallings 1980; Purkey \& Smith, 1982; Stallings \& Mohlman, 1981). Teachers who collect and analyze data from multiple forms and sources enhance their students' achievement and can facilitate whole school improvement (Marsh et al., 2006; Airola \& Dunn, 2011). Data-driven decisionmaking unites school stakeholders and mobilizes them to achieve school goals (Mawhinney, Frusciante, Aaron, \& Liu, 2002). Schools and students benefit when teachers and administrators use data effectively (Messelt, 2004).

Developing the school learning climate. The third dimension of the PIMRS framework for instructional leadership focuses on the school learning climate. This dimension is based upon "the notion that successful schools create an 'academic press' through the development of high standards and expectations and a culture that fosters and rewards continuous learning and improvement" (Hallinger, 2013, p. 16). The principal's leadership impacts the learning environment for teachers and students (James \& McCormick, 2009). When students perceive the school environment to be positive, they are more engaged in their learning and achieve at higher levels (Van Ryzin, 2011). Principals should work to develop and maintain a safe and orderly environment where students are supported and led to think of themselves as learners; this climate is key for promoting student achievement (Bryk, 2010). 
Protects instructional time. It is up to the principal to develop and enforce school-wide policies that allow for minimal interruptions to teacher instructional time so that teachers can effectively utilize their instructional and management skills with few disruptions (e.g., Bossert et al., 1982; Stallings, 1980; Wynne, 1980). Effective instructional leaders work to create an uninterrupted learning environment that supports students and teachers (Alig-Mielcarek and Hoy, 2005). "Too many intrusions into...instructional time impede teachers in their efforts not only to implement a rigorous curriculum but also to build the trusting environment that nurtures the learning" (Hong, 2001).

Provides incentives for teachers. Effective instructional leaders recognize that teachers are the school's greatest resource and acknowledge exemplary teaching (Smith \& Andrews, 1989). In a study of money, praise, and recognition as motivators, Latham and Wexley (1981) found that money is only slightly more effective than praise as an incentive; therefore, Hallinger (2013) suggests that principals frequently take advantage of opportunities to provide meaningful, deserved praise to teachers. The external and internal rewards of high performance promote job satisfaction (Locke \& Latham, 1990). Besides public recognition, other ways to provide incentives for teachers include building teacher self-confidence, feedback, creating challenge through goal-setting, and delegation of additional responsibilities (Locke et al., 2001). Effective leaders align staff incentives with the organization's vision and goals (Priem \& Rosenstein, 2000).

Provides incentives for learning. Instructional leaders can "create a school learning climate in which academic achievement is highly valued by students by providing frequent opportunities for students to be rewarded and recognized for their 
academic achievement and improvement" (Hallinger, 2013, p. 17). Research indicates that students thrive when recognized informally (such as in the classroom) and formally (such as in school-wide assemblies); the publicity of student recognition seems to be much more motivating than the price of the reward itself (e.g., Brookover et al., 1978; Rutter et al., 1979). Joyce and Calhoun (1996) claim that, "children respond to improved learning environments right away" (p. 177). This means that principals can effect swift change by creating a culture that recognizes and celebrates student achievement and the modeling of desired behaviors (Reavis, Vinson, \& Fox, 1999). "Principals who create an exciting and reinforcing learning environment will find that students and teachers will want to do what needs to be done" (Whitaker, 1997).

Promotes professional development. An effective instructional leader will be actively involved in promoting, planning, or providing professional development that is aligned with school goals (e.g., Clark, 1980; Little, 1982; Rutter, Maugham, Mortimore, Ouston, \& Smith, 1979). Teacher professional development has become an increasing focus of school leaders as a strategy for raising student achievement, and millions if not billions of federal, state, and district dollars are allocated to this effort (Borko, 2004). Bryk (2010) found that schools that were able to improve student achievement "used high-quality professional development as a key instrument for change" (p. 26). Eraut and Hirsh (2007) suggest that professionals can benefit from on-the-job learning opportunities in which they collaborate with and observe other professionals and give and receive feedback. School leaders should promote both formal and on-the-job learning opportunities for teachers to improve their professional capacity (Parise \& Spillane, 2010). 
Maintains high visibility. "The contexts in which the principal is seen provide one indicator to teachers and students of his/her priorities" (Hallinger, 2013, p. 17). Principals that prioritize works tasks to increase visibility in the classroom increase their interactions with teachers and students and positively impact instructional quality and student behavior (e.g., Brookover et al., 1982; Casey, 1980; Clark, 1980). Niece (1983) found that effective instructional leaders "are people oriented and interactional" (16). These principals interacted regularly with school stakeholders to remain visible and accessible. Teachers tend to perceive the school instructional climate more positively when principals conduct informal classroom observations (Ing, 2010). Blase and Blase (2003) also suggest that classroom walk-throughs are effective in making the principal accessible and visible to students and teachers. Andrews, Basom, and Basore (1991) emphasize the importance of principal visibility and presence in many leadership activities:

To create a visible presence in day-to-day activities, principals must model behaviors consistent with the school's vision; live and breathe their beliefs in education; organize resources to accomplish building and district goals; informally drop in on classrooms; make staff development activities a priority; and, most of all, help people do the right things and reinforce those activities ( $\mathrm{p}$. 100).

The visible principal has the opportunity to model his or her beliefs and to promote a positive instructional climate (Krug, 1992).

\section{Instructional Leadership: A Tall Order}

Given the vast definition of instructional leadership and its associated behaviors described above, it is understandable why principals could struggle to fit many of these tasks into their daily schedules. However, the sheer breadth of behaviors that are classified as instructional leadership makes it increasingly important for researchers to 
investigate principal implementation processes and to learn more about the instructional leadership experience from the teacher's perspective. In the next section of this paper, I explain the theoretical lens I have selected for examining principal perceptions and practices of instructional leadership and the interaction between the two. 


\section{Theories of Action: A Conceptual Framework}

For decades, Argyris and Schön have attempted to understand the complex relationship between individuals and organizations. In 1974, the researchers asserted that the actions that people take are by no means accidental; individual actions are instead the result of internal, mental maps used for planning, implementing, and reviewing courses of action. Whether conscious or subconscious, actors design and implement their own courses of action and are responsible for the consequences of those designs, whether intended or unintended (Argyris, 1987). Actors can often be unaware of their implemented designs and how they may be different from their espoused ideals (Argyris \& Schön 1974). The two theories of action, espoused theory and theory-in-use, are defined by Argyris \& Schön (1974), as follows:

When someone is asked how he would behave under certain circumstances, the answer he usually gives is his espoused theory of action for that situation. This is the theory of action to which he gives allegiance, and which, upon request, he communicates to others. However the theory that actually governs his actions is his theory-in-use, which may or may not be compatible with his espoused theory; furthermore, the individual may or may not be aware of incompatibility of the two theories (Argyris \& Schön, 1974, p. 6-7).

Table 2, shown on the next page, further demonstrates the contrast between espoused theory and theory-in-use. 
Table 2

Defining Theories of Action: Espoused Theory and Theory-in-use

Espoused theory

\section{Theory-in-use}

The ideals and values implied by a person's behavior; the map that he/she actually uses to take action his/her behavior is based on; the answer person would give when asked how they would behave in a given situation

Since most people fail to recognize a difference between their own espoused theory and theory-in-use, changing behavior can be a difficult task. For professional learning to occur, actors must reconcile what they "say they do and their explanations for their actions" with "what they actually do and the real reasons for their actions" (Robinson and Lai, 2006, p. 99). For actors, in this case, school leaders, to change their behavior, they must first realize that incongruity exists between their espoused theory and theory-in-use (Argyris, 1980). Recognition of this disparity is critical, Argyris (1980) asserted, because actions are most effective when espoused theory and theory-in-use are in alignment. Furthermore, discrepancies between the two theories can have a negative effect in educational organizations (Schön, 1983).

\section{Theories of Action and Instructional Leadership}

Due to the demonstrable emphasis placed on instructional leadership in both education research and in the VDOE's new evaluation framework, it is likely that many principals' espoused theory of instructional leadership would recognize the importance of its role in impacting teacher quality and student achievement, and they might aspire to spend time on the associated tasks. Conversely, the limited time that research indicates 
typical principals allocate towards instructional leadership tasks suggests that principal theories-in-use of instructional leadership guide school leaders to focus on other activities, possibly at the expense of their instructional leadership.

This potential discrepancy between principal perceptions and practices of instructional leadership demonstrates an incongruence of espoused theory and theory-inuse related to instructional leadership (Argyris \& Schön, 1974). The table below demonstrates how this incongruence of espoused theory and theory-in-use of instructional leadership could be manifested:

Table 3

Hypothetical Theories of Action for Instructional Leaders

Espoused theory

I know that instructional leadership is a critical factor in enhancing teacher quality and student outcomes in my school. I spend a lot of time working with teachers to improve their skills.
Theory-in-use I spend most of my time balancing my daily to-do list. When I have rare moments of free time, I usually catch up on emails and paperwork, and then do classroom walk-throughs if time is left over.

How do school leaders develop theories-in-use that differ from their espoused theory, and how could they learn to align the two? 


\section{Developing and Confirming Theories of Action}

The figure below outlines the processes involved in developing theories-in-use:

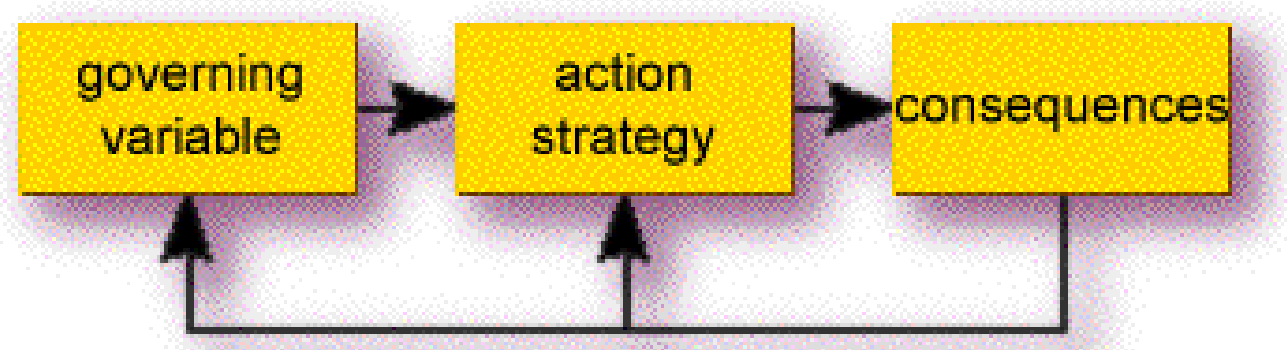

Figure 5

Processes of Theories-in-use (Argyris, Putnam \& McLain Smith, 1985)

Governing variables are the values that people attempt to keep within an acceptable range. Espoused theory and governing variables should be in alignment with one another. Governing variables consist primarily of implicit values, ideas, feelings, and intentions that may not be outright discussed; however, they are critical in providing information from which actors should base their decision-making (Argyris \& Schön, 1974). For an effective school leader, these values could be student achievement, teacher quality, building management, school safety, parent engagement, or other factors surrounding the development and maintenance of what the leader believes to be a successful school.

Often, actions impact different governing variables in different ways, so trade-off is required in which actors prioritize certain governing variables over others, depending on the nature of the situation (Argyris \& Schön, 1974). For example, a principal may spend the majority of a day completing paperwork in his office when a major deadline is 
looming, at the expense of completing classroom walk-throughs or meeting with teachers. Action strategies are the strategies taken by the actor that purposefully attempt to keep the governing variables within an acceptable range (Argyris \& Schön, 1974). The principal mentioned above chose an action strategy centered on the value of school management so that he did not become neglect in organizational duties. Finally, the selected action strategy results in consequences which can be intended or unintended for the actor and for others (Argyris \& Schön, 1974). As a result of spending the day in his office working on paperwork, the principal may have failed to complete other tasks that needed his attention.

Actors deem the effectiveness of the particular action strategy based on whether the consequences balance the governing variables as desired (Argyris \& Schön, 1974). Therefore, if completing a report was the most important variable at the time, the principal is likely pleased with the consequences of his action strategy and deems it effective. When the consequences of an action strategy were the ones intended by the actor, the match of intention and outcome confirms the theory-in-use. Conversely, when the consequences are unintended or counterproductive to satisfying the governing variables, there is a mismatch of intention and outcome that must be addressed (Argyris \& Schön, 1974).

\section{Learning to Change Behavior}

There are two potential responses to the misalignment of intentions and outcomes (Argyris \& Schön, 1978). The first and simplest response is to reflect upon and change the action strategy; this process focuses on creating a more effective, efficient action technique and does not involve making any changes to the governing variable(s). In this 
case, the actor simply seeks to implement a new course of action that he/she hopes will satisfy the existing governing variable(s) and achieve the desired consequences (Argyris \& Schön, 1978). This response is referred to by Argyris and Schön (1978) as single loop learning and is illustrated in the figure below:

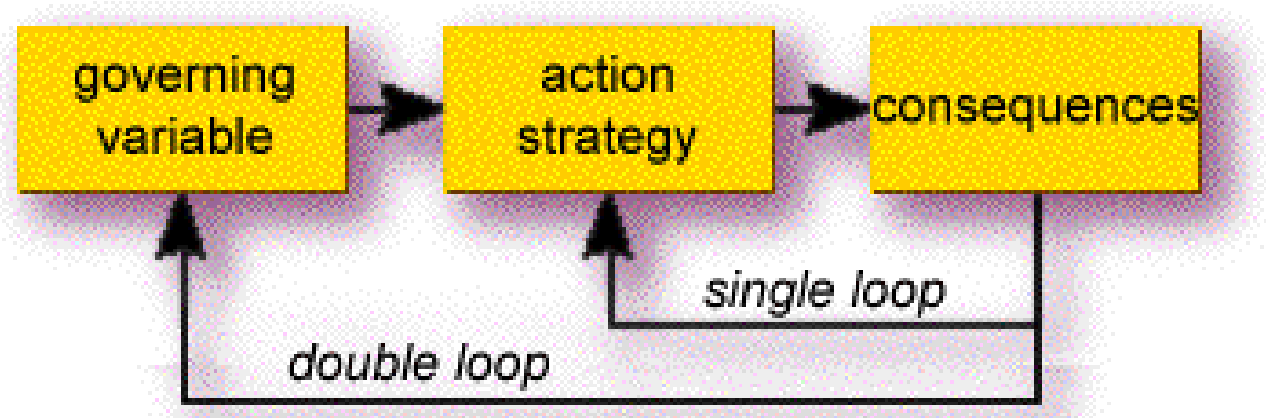

Figure 6

Single and Double Loop Learning (Argyris, Putnam \& McLain Smith, 1985)

Single loop learning, the model Argyris finds to be most prevalent in all cultures, focuses on routines, controlling the environment unilaterally, defensiveness, the desire to win, and the need to protect oneself (1980). When our actions do not produce desired results, the quickest solution is to search for and implement new actions that will satisfy our needs.

Double loop learning, also illustrated in Figure 6, is a much more complex process. In double loop learning, actors submit their governing variables to critical scrutiny. This critical examination can lead to an alteration of the governing variables and a shifting framework for action strategies and consequences (Argyris \& Schön, 1978). Double loop learning is a reflective process that focuses on "why" rather than "how" 
outcomes are desired and achieved. Hallmarks of double-loop learning include seeking valid information and data, sharing control with participants, open communication, and public testing of assumptions and hypotheses (Argyris and Schön, 1996).

Double-loop learning is the more effective way of making informed decisions about the way we design and implement action (Argyris, 1974). In double loop learning, "Every significant...action is evaluated in terms of the degree to which it helps the individuals involved generate valid and useful information (including relevant feelings), solve the problem in a way that it remains solved, and do so without reducing the present level of problem solving effectiveness" (Argyris, 1976, p. 21-22). Argyris claims that double-loop learning is necessary if practitioners and organizations are to make informed decisions in rapidly changing and often uncertain contexts (1990).

\section{Application of Theories of Action to Instructional Leadership}

This project attempted to uncover theories of action among participating elementary principals. Information relating to the attitudes, actions, and values that elementary principals espouse relating to instructional leadership was collected and analyzed by the researcher. Principal action strategies were examined through an intervention that collects information about specific principal instructional leadership behaviors. Principal theories-in-use of instructional leadership were deduced from examination of these action strategies (Argyris, 1974). The researcher hypothesized, in accordance with Argyris' (1980) assertion, that variability would exist between principal espoused theories and action strategies of instructional leadership. Therefore, one action product of this research project was intended to provide a foundation for principal double-loop learning. In order for double-loop learning to occur, principals must 
recognize the incongruence of their espoused theory and theory-in-use (Argyris, 1980). Therefore, this process included discussion and reflection upon relevant data. Recognizing and addressing the potential disparities between espoused theory and theories-in-use, and taking purposeful steps to align the two, can lead to more effective actions and enhanced professional learning, growth, and practice (Argyris, 1980). 


\section{Research Methods}

In this capstone project, I explored the nature of principal instructional leadership in Washington County in order to: 1) ascertain principal readiness for the implementation of the new principal evaluation system, and 2) to use that assessment of readiness to assist individual principals and district leaders to increase readiness. In this section, I described the methods that were used to explore these issues.

\section{Research Questions}

As described in section one of this paper, the following central research question anchored my project: What is the nature of instructional leadership in Washington County elementary schools? To guide my work on the central question, I asked several sub questions.

- Sub Question 1: How do Washington County elementary principals define instructional leadership, and what practices do they associate with it?

- Sub Question 2: How do various stakeholders (the principal, teachers, and direct supervisor) perceive the principal's implementation of instructional leadership in the school?

- Sub Question 3: What is the relationship between principal espoused theory (beliefs) and theories-in-use (practices) of instructional leadership? 
The first sub question was designed to uncover principal beliefs, also known as espoused theory, regarding instructional leadership. In order to answer the second sub question, I relied upon the perspectives of multiple data sources regarding principal implementation of instructional leadership to determine principal action strategies and theories-in-use. Data analysis for the third sub question helped to understand the relationship between principals' perceptions (espoused theory) and practices (theory-inuse) of instructional leadership. See Table 4 for a summary of the data collected to answer each question.

Table 4

Research Sub Questions and Relevant Data Collected

\begin{tabular}{|c|c|}
\hline Research Question & Data Collected to Answer Question \\
\hline $\begin{array}{l}\text { 1. How do Washington County } \\
\text { elementary principals define } \\
\text { instructional leadership, and what } \\
\text { practices do they associate with it? }\end{array}$ & $\begin{array}{l}\text { (a) Answers to semi-structured interview } \\
\text { protocol (Appendix A) }\end{array}$ \\
\hline $\begin{array}{l}\text { 2. How do various stakeholders (the } \\
\text { principal, teachers, and direct } \\
\text { supervisor) perceive the principal's } \\
\text { implementation of instructional } \\
\text { leadership in the school? }\end{array}$ & $\begin{array}{l}\text { (a) Results of PIMRS 360-degree } \\
\text { instrument and (10) researcher-written } \\
\text { questions added to the instrument }\end{array}$ \\
\hline $\begin{array}{l}\text { 3. What is the relationship between } \\
\text { principal espoused theory (beliefs) and } \\
\text { theories-in-use (practices) of } \\
\text { instructional leadership? }\end{array}$ & $\begin{array}{l}\text { (a) Answers to semi-structured interview } \\
\text { protocol } \\
\text { (b) Results of the PIMRS 360-degree } \\
\text { instrument }\end{array}$ \\
\hline
\end{tabular}

\section{Research Design}

Setting and Participants. The study took place in Washington County Schools, a large, rural school division in Southside Virginia. The division has ten elementary 
schools, and five of these schools were selected for participation via purposive sampling methods. Criteria for inclusion in the study were as follows:

- a school with only one leader (no assistant principal)

- declining student achievement trends in math and reading

- a school leader that had been in place for at least five years

Of the five school principals who met the criteria and were invited to participate in the study, three consented to participate. These schools will be referred to throughout this paper as School A, School B, and School C.

. School A is a small, rural school and is similar in size to Schools B and C. School B is comprised of just over 200 students in grades PK-5. Due to its central location, it also serves as a district-wide special education center for students with certain types of disabilities and exceptionalities. School C is a small, high-poverty school located in one of the county's most rural areas. It also currently houses just over 200 students. All of these elementary schools have seen declining student achievement in reading and math in recent years. The principals at each school also indicated to the researcher that it was becoming increasingly difficult to find time for instructional leadership among all the other requirements of the principalship, and they were anxious about the implications of the new principal evaluation linked to student achievement (Personal Conversations, April 2013).

Data Collection Plan and Rationale. The data were collected in two distinct phases, the first of which consisted of gathering qualitative data, and the second generated quantitative data. Data sources included the school principals from each elementary school and all instructional personnel working at each school site. In addition, 
the division Director of Elementary Education participated in the project to provide the perspective of Central Office personnel. A description and overview of the methodology for each phase of data collection is described in Table 5 below.

Table 5

Overview of Research Methodology

\begin{tabular}{|c|c|c|c|c|}
\hline & Rationale & Implementation & Method & Sample \\
\hline $\begin{array}{l}\text { Phase I: } \\
\text { School } \\
\text { Leader } \\
\text { Interviews }\end{array}$ & $\begin{array}{l}\text { Provides } \\
\text { personal insight } \\
\text { into principal } \\
\text { beliefs and } \\
\text { attitudes about } \\
\text { instructional } \\
\text { leadership }\end{array}$ & $\begin{array}{l}\text { Open-ended } \\
\text { questions } \\
\text { focusing on } \\
\text { leader's } \\
\text { definitions, } \\
\text { perceptions, and } \\
\text { types of } \\
\text { instructional } \\
\text { leadership } \\
\text { activities }\end{array}$ & $\begin{array}{l}\text { Identify patterns in } \\
\text { coded } \\
\text { transcriptions; } \\
\text { outline principal } \\
\text { beliefs; compare } \\
\text { beliefs to the } \\
\text { research base and to } \\
\text { data from Phase II }\end{array}$ & $\begin{array}{l}\text { (3) school } \\
\text { leaders from } \\
\text { (3) rural, } \\
\text { high poverty } \\
\text { schools with } \\
\text { declining } \\
\text { achievement } \\
\text { trends }\end{array}$ \\
\hline $\begin{array}{l}\text { Phase II: } \\
\text { 360-Degree } \\
\text { Instrument }\end{array}$ & $\begin{array}{l}\text { Quantitative } \\
\text { measure of } \\
\text { school leaders' } \\
\text { instructional } \\
\text { leadership } \\
\text { practices from } \\
\text { multiple } \\
\text { perspectives }\end{array}$ & $\begin{array}{l}\text { Online } \\
\text { administration of } \\
\text { PIMRS } \\
\text { instrument to data } \\
\text { sources, } \\
\text { collecting } \\
\text { information about } \\
\text { perceptions of } \\
\text { principal's } \\
\text { instructional } \\
\text { leadership from } \\
\text { each data source }\end{array}$ & $\begin{array}{l}\text { Descriptive } \\
\text { statistics to identify } \\
\text { areas of agreement } \\
\text { and disagreement } \\
\text { among data } \\
\text { sources; Draw } \\
\text { conclusions about } \\
\text { principal theories of } \\
\text { action; Compare } \\
\text { implementation } \\
\text { practices to } \\
\text { research base }\end{array}$ & $\begin{array}{l}\text { (3) school } \\
\text { leaders, the } \\
\text { instructional } \\
\text { staff in each } \\
\text { school, and } \\
\text { the division } \\
\text { Director of } \\
\text { Elementary } \\
\text { Education }\end{array}$ \\
\hline
\end{tabular}

\section{Data Collection Phase I: Interview with School Principals}

Ritchie \& Lewis (2003) suggested that face-to-face interviews are a particularly appropriate and flexible data collection methodology when the primary focus of research is gaining insight and understanding. Therefore, to collect information about principal 
espoused theory of instructional leadership, the researcher began with semi-structured, open-ended interviews with the school administrators. The interview protocol included six major themes, illustrated in the concept map below:

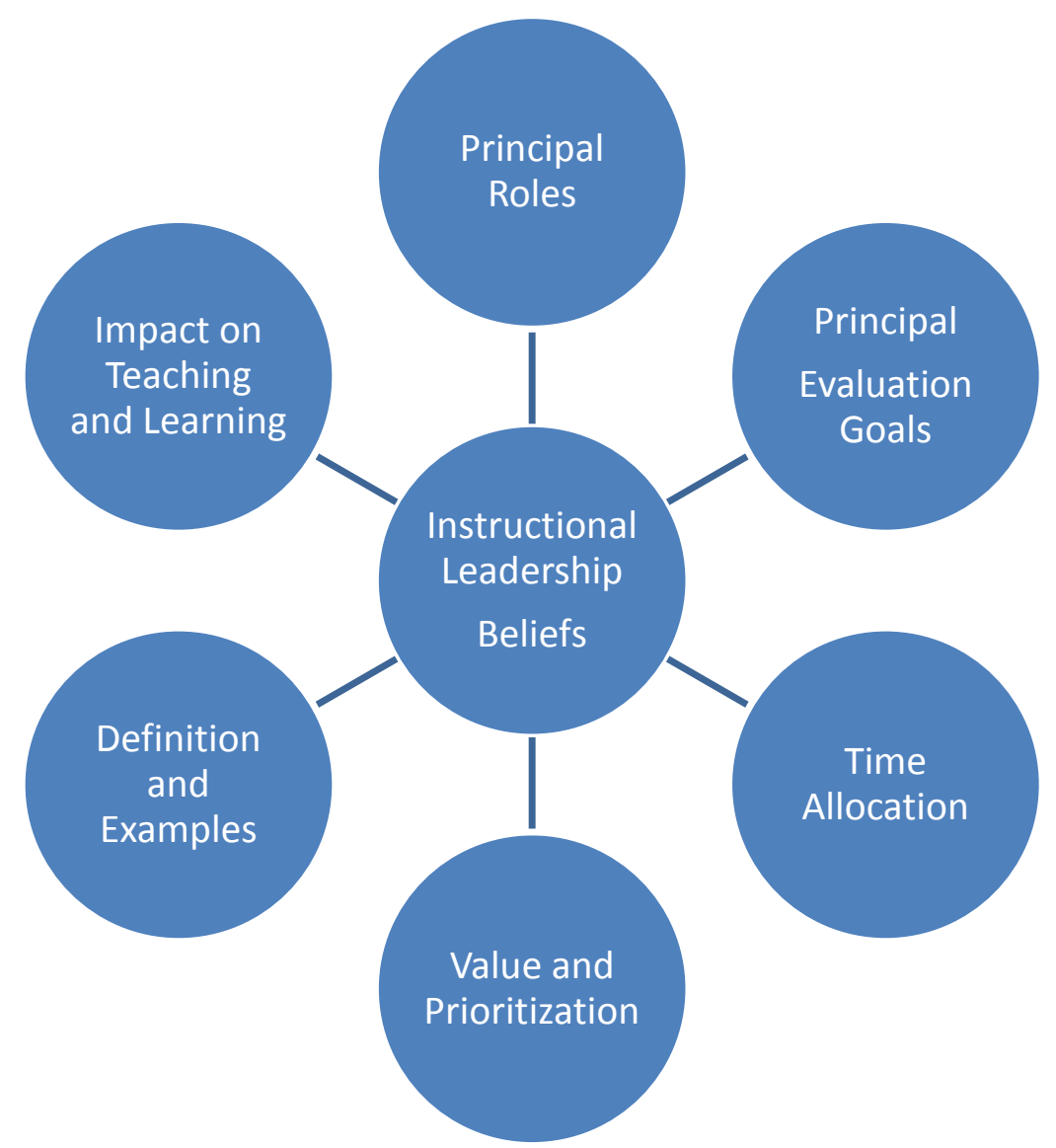

Figure 7

Themes of Principal Interview Protocol

A copy of the interview protocol can be found in Appendix A. Interviews were recorded and the researcher immediately transcribed data. Each subject signed a copy of the transcription to indicate that the data contained therein accurately reflected the content of the interview. 
In alignment with the recommendations of Cohen, Manion, and Morrison (2007), interview questions were clearly structured; additionally, the questions were open-ended and designed to encourage the interviewee to speak freely and feel comfortable supplying responses (Clough \& Nutbrown, 2007). The content of the questions moved from broad and general topics, such as the principal's ideas about overall school goals, to more specific inquiries about the meaning of instructional leadership, ways it is practiced, and the amount of time spent engaged in it. To establish a level of comfort and rapport, recommended by Opie (2004), each school leader was interviewed individually in her office on a date and time selected by the participant; additionally, each participant was fully aware of the purpose of the interview and the major topics to be discussed prior to the interview taking place.

\section{Data Analysis Procedures for Phase I: Interview with School Principals}

Data analysis in qualitative research manages words, language, and the meanings implied by these linguistic cues (Miles \& Huberman, 1994). Using a grounded theory approach, I aimed to systematically develop the theory derived directly from that data, rather than develop a theory and then seek out evidence to verify it (Dey, 1999). In this way, grounded theory "seeks to ensure that the theory emerging arises from the data and not from some other source" (Crotty, 1998, p. 78).

I first engaged in inductive coding procedures. While reading the data line by line, I noted start codes and searched for emerging themes (Strauss \& Corbin, 1998). These original codes were modified as I worked through subsequent interviews and cases, using comparative pattern analysis to identify recurring patterns in the data. Strauss and Corbin (1998) emphasize the importance of meaning-making across cases, "to open up our 
minds to the range of possible meanings, properties, dimensions, and relationships inherent in any bit of data...when we move on to the next case and those that follow, we are more sensitive both to the possibilities and to what else the new cases teach us" (p. 88, emphasis in original). After the recursive analysis of each of the three interview data sets, codes were clustered into several primary themes: knowledge, support, collaboration, progress monitoring, visibility, and impact. These qualitative data collected during Phase I of this project contributed to answering the first research sub question: How do Washington County elementary principals define instructional leadership, and what practices do they associate with it?

After the inductive coding procedures described above, I then engaged in deductive coding procedures to search for answers to the first research sub question, seeking to identify principal perceptions of instructional leadership and to compare those perceptions to the research base. When doing this, I examined the data line by line and mapped each principal's responses alongside a copy of the PIMRS framework for instructional leadership (Hallinger \& Murphy, 1985). A copy of the framework is included as Appendix B.

Analyzing the data in this way allowed me to note research-based areas of instructional leadership that the participants focused on as well as those that they did not emphasize during the interviews. This analysis provided information about the principals' knowledge of instructional leadership as compared to the research base, and what gaps in knowledge and/or implementation may exist for individual principals and in aggregate. Additionally, when parts of a principal's definition of instructional leadership were not included in the PIMRS framework, I looked to the literature to determine whether the 
behavior had been classified as effective instructional leadership by other researchers. Table 6 below summarizes data analysis from Phase I of the project and how data contributed to answering the first research sub question.

Table 6

Phase I Data Analysis

\begin{tabular}{|l|l|}
\hline \multicolumn{1}{|c|}{ Data Analysis } & \multicolumn{1}{c|}{ Results } \\
\hline $\begin{array}{l}\text { Coded interview data, analyzed inductively } \\
\text { and deductively (Responses to protocol in } \\
\text { Appendix A) }\end{array}$ & $\begin{array}{l}\text { Describe principal espoused theory } \\
\text { (beliefs) of instructional leadership (SQ 1) }\end{array}$ \\
$\begin{array}{l}\text { Map individual principal beliefs to research } \\
\text { base via PIMRS Framework; analyze in } \\
\text { aggregate to search for common gaps } \\
\text { among sample (SQ 1) }\end{array}$ \\
\hline
\end{tabular}

\section{Data Collection Phase II: Administration of PIMRS Instrument}

The second phase of data collection was focused on collecting information from school stakeholders about the instructional leadership behaviors of each principal. To do so, the PIMRS questionnaire, which is based on the research-based framework for instructional leadership presented earlier in this document, was administered to participating school leaders, their direct supervisor (the division Director of Elementary Education), and instructional personnel in each school. Non-instructional personnel (school secretary, school custodians, bus drivers, etc.) were excluded from participation because they are not the intended targets of instructional leadership behaviors. Sample sizes and response rates for each school site are listed in Table 7 on the next page. 
Table 7

Survey Sample Size and Response Rates

\begin{tabular}{|l|l|l|l|}
\hline \multicolumn{1}{|c|}{$\begin{array}{c}\text { School } \\
\text { Site }\end{array}$} & \multicolumn{1}{|c|}{$\begin{array}{c}\text { Administrator } \\
\text { Sample }\end{array}$} & $\begin{array}{c}\text { Instructional } \\
\text { Personnel Sample }\end{array}$ & \multicolumn{1}{c|}{$\begin{array}{c}\text { Supervisor } \\
\text { Sample }\end{array}$} \\
\hline School A & $\mathrm{N}=1$ & $\mathrm{~N}=14$ & $\mathrm{~N}=1$ \\
$100 \%$ response & $67 \%$ response & $100 \%$ response \\
& $\mathrm{N}=1$ & $\mathrm{~N}=17$ & $\mathrm{~N}=1$ \\
& $100 \%$ response & $65 \%$ response & $100 \%$ response \\
\hline School B & $\mathrm{N}=1$ & $\mathrm{~N}=17$ & $100 \%$ response \\
& $100 \%$ response & $100 \%$ response & \\
\hline
\end{tabular}

The PIMRS instrument was administered to each group in an online format using the QuestionPro website, software made available to student researchers at the University of Virginia. A copy of the principal, teacher, and supervisor forms of the PIMRS instrument can be found in Appendix C, D, and E, respectively. Additionally, ten questions were added to the PIMRS instrument by the researcher to collect information about which instructional leadership practices each data source deemed most important in impacting teacher professional growth and capacity. Each of these researcher-written questions very closely mirrored the format and language of the existing PIMRS instrument. For example, immediately after a PIMRS section related to the frequency of principal behaviors regarding framing the school goals, the researcher inserted a question asking the survey participant which of the goal-framing behaviors he/she found to be the most important contributor to building teacher professional skill and capacity. One question, written by the researcher following this format, was inserted after each of the ten existing sections of the teacher, principal, and supervisor forms of the PIMRS. A 
copy of the ten additional questions included in each form of the PIMRS instrument is included in Appendix F.

Description of the PIMRS Instrument. The Principal Instructional Management Rating Scale (PIMRS) was created as a tool for assessing instructional leadership behaviors (Hallinger, 1983; Hallinger \& Murphy, 1985). It has been used in over 200 studies and over 25 countries for empirical investigation into the role of the principal as an instructional leader. The instrument aims to help instructional leadership become a more practice-oriented, research-based construct. It is a validated survey instrument that meets high standards of reliability. Designed as a 360-degree intervention, the instrument is intended to be administered to principals, their supervisors, and instructional staff members in their schools.

The PIMRS framework, described and expanded upon in the literature review of this paper, includes three primary domains: defining the school mission, managing the instructional program, and developing the school learning climate. There are multiple functions within each domain, and a total of ten. These ten functions are seen as the primary responsibilities of instructional leaders, gleaned from decades of research.

Each of the functions of the PIMRS framework is further delineated into five specific behaviors, making a total of fifty, and those items comprise the PIMRS questionnaire. Participating principals, teachers, and supervisors are asked to rate the frequency with which the principal performs each behavior, with possible responses ranging from "never" to "almost always." Results of the instrument serve as an intervention for school leaders by allowing them to critically examine and reflect upon the ways that they use their time for instructional leadership. 


\section{Data Analysis Phase II: PIMRS Instrument Results}

The second phase of this project involved the administration of the PIMRS instrument, described in detail earlier in this paper, at each school site. The school principal, teachers/instructional staff in the school, and the division Director of Elementary Education were invited to participate in the 360-degree survey. The results of this questionnaire allowed me to quantify perceptions of each data source regarding the principal's instructional leadership implementation strategies. These data answered the second sub-question regarding principal theories-in-use of instructional leadership: How do various stakeholders (the principal, teachers, and direct supervisor) perceive the principal's implementation of instructional leadership in the school?

Survey data collected from each source (principals, supervisors, and teachers) were analyzed separately, with the individual school as the unit of analysis. The results of the supervisor, principal, and teacher questionnaires were analyzed using descriptive statistics. The researcher noted areas of disagreement among the data sources, or those where the average/mode teacher response was higher or lower than the principal or supervisor response to a survey item. Based on these data points, the researcher drew conclusions about the nature of the principal's implementation of instructional leadership activities.

In addition to finding out about principal implementation of instructional leadership, survey data were also analyzed with the purpose of discovering the instructional leadership practices that are perceived as most beneficial in improving teacher professional capacity. The researcher compiled descriptive statistics to compare the responses of principals, the supervisor, and instructional staff to each question 
addressing this issue. Table 8 , shown below, summarizes data analysis procedures and how the PIMRS data contributed to answering the second research sub question.

Table 8

Phase II Data Analysis

\begin{tabular}{|l|l|}
\hline \multicolumn{1}{|c|}{ Data Analysis } & \multicolumn{1}{c|}{ Results } \\
\hline $\begin{array}{l}\text { Run descriptive statistics on data from } \\
\text { PIMRS 360-degree instrument and } \\
\text { researcher-developed questions from each } \\
\text { data source }\end{array}$ & $\begin{array}{l}\text { Determine principal theories-in-use } \\
\text { (implementation) of instructional leadership } \\
\text { as perceived by various data sources (SQ 2) }\end{array}$ \\
$\begin{array}{l}\text { Determine gaps in research-based } \\
\text { instructional leadership implementation } \\
\text { practices, both individually and in } \\
\text { aggregate (SQ 2) }\end{array}$ \\
$\begin{array}{l}\text { Determine which instructional leadership } \\
\text { activities data sources deem most likely to } \\
\text { increase teacher capacity (SQ 2) }\end{array}$ \\
\hline
\end{tabular}

\section{Researcher Bias}

The researcher works for Washington County Schools and is employed at one of the schools from which data were collected. Therefore, the researcher was cognizant of the potential bias at each stage of data collection and analysis. To avoid the potential for misrepresenting the context of data, that from the researcher's place of work were analyzed last and using identical methodology of that of the previous school sites, following the protocol described above.

\section{Methodological Limitations}

The research project has several methodological limitations. First, the nature of the study deals wholly with individual perceptions and implementation of instructional 
leadership. At each school site, the study involved a rather small sample size. Each of the schools house only two classes per grade level; therefore, these teachers, along with a handful of resource teachers and special education teachers, comprised an average sample size of 21 for the three participating schools. However, since the nature of the project does not attempt generalization of results outside of the school context, the data collected, although small in number, were relevant to the individual school principal.

Both phases of the research design have some limitations. Gomm (2004) described 'demand characteristics' in interviews, or times when the interviewee provides the information that they believe the situation requires. Since most principal preparation programs focus on instructional leadership to some extent, it is likely during interviews that principals were aware of the "buzz words" surrounding instructional leadership and could give the researcher the "right answers" even if those answers were not truly representative of their views. However, the researcher attempted to minimize its effects by asking very open-ended questions, leaving the principal to rely upon their current knowledge and beliefs. The main purpose of the interview was to uncover principal espoused theory of instructional leadership, defined previously in this paper as "the answer a person would give when asked how they would behave'. It is arguable that the beliefs expressed in the interviews, since the principals claimed them as their own at that time, did accurately capture espoused theory of instructional leadership.

An additional weakness of interviews is described by Denscombe (2007) as the 'interviewer effect': "In particular, the sex, the age, and the ethnic origins of the interviewer have a bearing on the amount of information people are willing to divulge and their honesty about what they reveal" (p. 184). The researcher tried to counteract this 
limitation by making the participant aware of the purpose and major topics of the interview in advance to put her at ease. Additionally, the researcher was personally familiar with each school leader prior to her participation in the study, making it easier to establish continued rapport and build relational trust.

Some of the potential limitations of survey data were avoided due to the use of a validated instrument in this study. However, several typical limitations associated with the collection of survey data were present in this study. In collecting data from teachers, a limitation rests in the possibility that the perceptions of teachers who participated in the survey may be different from those that did not elect to participate. This limitation is termed non-response error, described by Visser, Krosnick, and Lavrakas (2000) as "the extent that the sampled elements from whom no data are gathered differ systematically from those from whom data are gathered" (p. 233). The researcher implemented the following suggestions, made by Visser and others, to attempt to minimize non-response error:

Sending letters to potential respondents informing them that they have been selected to participate in a study and will soon be contacted to do so, explaining that their participation is essential for the study's success because of their expertise on the topic, suggesting reasons why participation will be enjoyable and worthwhile, assuring respondents of confidentiality, and informing them of the study's purpose and its sponsor's credibility. Researchers also make numerous attempts to contact hard-to-reach people and to convince reluctant respondents to participate (p. 234).

Another potential limitation of survey data collection involves the self-disclosure required by participants. Despite the anonymity of the survey, it is possible that respondents also may have rated their principals more highly due to fear of retribution. Visser and colleagues (2000) noted that when sensitive issues are being approached through a survey, a method that allows the respondent to complete the survey in private 
may elicit more honest responses. Since the survey was administered online, participants were able to access the survey in a private setting where they were comfortable, such as their personal, home computer.

Another potential limitation of this research is the emphasis in both the literature review and research design upon Hallinger and Murphy's work in defining and measuring instructional leadership. However, it is important to note that the PIMRS framework, while created by Hallinger and Murphy (1985), was based on a critical review of literature available at the time, and the PIMRS instrument continues to be updated and has been modified and validated as recently as 2013. Additionally, the literature review of this paper cited a vast base of contemporary research that continues to support the behaviors included in the domains and functions of the PIMRS framework as valid instructional leadership practices today. Therefore, the researcher concludes that the PIMRS was an appropriate framework and instrument for defining and measuring instructional leadership. 


\section{Position Paper}

In this section of my capstone, I summarized the conclusions drawn from data to answer my specific research questions. Subsequently, I make recommendations for impacting the problem of practice identified in this project and discuss the implications of my findings for further research. I first examined the data using the individual school as the unit of analysis and then across each of the three school settings. Evidence and findings are presented related to each of the following areas:

- Principal espoused theory of instructional leadership

- Principal theory-in-use of instructional leadership

- Congruence of theories of action

- The principal's role in enhancing teacher quality

- Recommendations in context

- Implications of findings for further action and research

\section{Principal Espoused Theory of Instructional Leadership}

As previously noted, the following primary themes emerged from grounded theory analysis of principal interview data:

- Knowledge

- Support

- Collaboration

- Progress Monitoring

- Visibility

- Impact 
In this section of the position paper, I summarized principal views related to each of these themes in order to describe the espoused theories of instructional leadership among the participating school leaders. This evidence and discussion contributes to answering the first research sub-question: How do Washington County elementary principals define instructional leadership, and what practices do they associate with it?

Knowledge. All of the principals in this study clearly emphasized the role of knowledge in effective instructional leadership. The types of knowledge believed to be required of them as instructional leaders primarily included the tenets of all of the core content areas, various teaching and instructional strategies, and changing VDOE regulations that impact school stakeholders. Principal A reinforced the importance of the principal's ability to perform the job of a teacher capably, stating "I really believe that the principal should be able to do everything that he or she is expecting the teachers to do and be able to go in the classroom and model that." The school leaders also felt that their role as instructional leaders included continuous learning and growth over time and remaining current on research-based best practices in education and sharing those trends with instructional staff members. "Instructional leadership is the ability to research, discover, and present ideas that will enhance the educational process, "was Principal C's definition of instructional leadership.

Despite the responsibility of the school leaders to be highly skilled and knowledgeable about teaching and learning, those participating in this study also demonstrated the idea that they must tread carefully with teachers when sharing their expertise. Principal B shared, "If I were to come across as, 'I know everything. I'm a dictator, and you can't teach,' then that would be a turn off right from the beginning." 
The knowledge acquired by school leaders through their experiences and education must be shared in a positive way that encourages teacher growth and development, clearly linked to the second theme of principal espoused theory that emerged in this study: support.

Support. The school leaders in this study all hold espoused theories of instructional leadership that focus on supporting teachers and students in a variety of ways. One of the primary administrative roles that Principal C engages in is, "being an encourager...for both the teachers and the students." Principals A and B both referred to this role also; they described themselves as constant "cheerleaders," encouraging their staff members and celebrating large and small successes.

Beyond the encouragement and celebration they offer, Principal A specifically mentioned the responsibility to "provide support and direction to any instructor in the building" and the importance she finds in supporting teachers through her instructional leadership: "I tell teachers that I'm not coming in the classroom to 'get you.' I want to look at what you're doing, and if I can offer some suggestions...then I will do that. It's a means of support, because that's what I think my job is."

In addition to supporting teachers through encouragement and sharing instructional strategies and resources, the school leaders in this study all shared stories about experiences in which they felt that their instructional leadership supported students. This support was done though taking a personal interest in mentoring at-risk students (Principal A), refusing to give up on low-achieving students even when most other adults had (Principal B), or providing content-area expertise and tutoring to struggling students (Principal C) to help them achieve at their highest potential. Regardless of the avenue, 
supporting students was believed to be one of the most important roles of effective instructional leaders.

Collaboration. In addition to acquiring knowledge and using it to support teachers and students, the principals involved in this study all felt strongly that collaboration was one of the most important aspects of instructional leadership. Principal A spoke of her attempts to build a collaborative atmosphere in her school:

I don't sit in my office and just give out directions.... When I came here it was more of an 'everybody in their own classroom doing their own thing' kind of school. We are more of a collaborative village now. We share. Teachers have no problem helping each other. So, I think that's a great benefit. They share resources and ideas and help each other out.

Principal C also emphasized the sharing of ideas among teachers and school leaders: "I'm not a dictator. I try to bring everybody in and let their ideas come forth. As in, 'what do you see?' or 'what's working for you?' Everyone is sharing and tapping into ideas that could help them and their students." Effective instructional leadership according to the principals in this study builds that culture of collaboration and involves a team effort. Principal B emphasized her belief that, "instructional leadership is all about being a part of a greater team, listening to your staff, and working together to continually improve...Being prepared for change, continuous change, and being able to work together to achieve and meet whatever that change requires."

In addition to creating collaborative school environments where teachers and administrators work as a team, each of the principals mentioned times when they had collaborated with teachers towards the goal of improving instruction. In each instance, the teacher and leader talked, negotiated, and planned together about what changes needed to occur to enhance teacher quality. The principals noted that they tried to engage 
the teachers in this dialogue so that they took ownership throughout the process and were more receptive to change and experimentation. The principals were even open to changing their own ideas, as Principal A shared:

I really try to listen. There are some things that are non-negotiable, but I really try to listen to the teachers and if they have a legitimate argument that I think is valid, then I don't mind saying, 'Ok, I was wrong, let's try it this way.' Because it's all about results. It doesn't matter how we get there as long as we get there.

In each case that the principals shared, the teachers were open-minded and responded positively, and the principals saw improvement in their instructional capacity over time as the improvement plans were implemented in the classrooms.

Progress Monitoring. In addition to collaboration focused on improving teacher professional skill and capacity, instructional leadership involves a great deal of progress monitoring for the principals involved in this study. Each school leader claimed that keeping up with student progression through the curriculum was a critical element of her instructional leadership. The principal of School A created a daily, 30-minute remediation and enrichment block where students who need extra help can be tutored in targeted skills and students who are advanced can participate in curricular extension activities. She also frequently engages in conversations with teachers about which students are struggling and the intervention plans that are in place to help those students be successful.

Principal B also expressed the belief that instructional leadership requires handson progress monitoring. "My priority is...being sure that every child is getting what they need to be successful and they're moving forward and not staying still and moving backwards" She accomplishes this goal through weekly, grade-level data meetings with teachers where they share data portfolios, including pre and post test results and 
intervention plans. In the meetings, "we're trying to close any gaps that may exist between instruction and prescriptive intervention."

In addition to working with teachers, the principal at School $\mathrm{C}$ also takes a very hands-on approach with students as part of her instructional leadership responsibilities. “I'm also checking students' work, literally, papers. They have to show me tests and things of that nature so that I can make sure that they are on target and where they need to be. I don't mind keeping them after school. I help tutor, and I don't mind to do detention for students to re-do work if they need to." Principal C also mentioned a progress-monitoring program she has been implementing with reading teachers in the primary grades (K-2) to ensure that students are reading at grade level by the end of second grade. Although each of the three schools in this study have unique needs depending on the student population, each principal focuses a great deal of her time and effort on monitoring student progress and making sure that students are moving appropriately through the curriculum.

Visibility. The principals in this study all emphasized the visibility that they felt was required of them as instructional leaders. This manifested in different ways, whether through conducting formal classroom observations, informal classroom walk-throughs, or having conversations with teachers throughout the day. Principal A placed particular value on "those conversations...when I'm talking to teachers and I'm asking them about how things are going and they tell me about a child and I might say, 'Have you tried this? Think about doing this..." 'She felt that by venturing out of her office and spending time engaged in talking with teachers, she created a more relaxed and comfortable work environment and boosted teacher morale. 
Principal B concurred that, "I'm highly visible in the classrooms" and felt that her visibility contributed to a sense of teamwork and collaboration between teachers and school leaders. When asked how she manages her tasks in order to spend the amount of time in the classroom that she desires, she stated: “...it's all about prioritizing-you have to do that. Or else, if you go into it trying to do everything, you find at the end of the year, 'I haven't been in the rooms' or 'I've only been to this teacher once' or 'I haven't ever been to see this teacher in action', so if you don't plan for it, it doesn't happen." Principal $\mathrm{C}$ also focuses on being highly visible to teachers and students and also struggles to find the time to do so. She claimed, "I try to make a visit to each classroom every day to see what's going on, and then address the needs as I see them with the teachers." Despite her intentions to spend as much time as she can in the classrooms, she finds that,

Time is a great distractor...I will have more time now, because we [the school division] have a new plan in place where every Wednesday a retired principal is going to be here to free me up to do observations and have conversations that can help teachers. I'm excited about that, because I've been needing that time.

The sentiments of Principals B and C echo the findings of Horng, Klasik, \& Loeb (2010) and Goldring and colleagues (2007), which concluded that principal time allocation for instructional leadership is often limited to an average of $15 \%$ to $30 \%$ per day and that other managerial and supervisory tasks take the majority of the average principal's daily work time.

Impact. Despite the challenge of finding time to engage in instructional leadership, the school leaders in this study had no doubts about the impact that their role as instructional leaders could have on teachers, students, and core area instruction in their 
schools. Principal A emphasized the value of instructional leadership over the other managerial and administrative tasks that school leaders have:

You know, I think that is the most important thing that you can do, the instructional leadership piece. Because you can find somebody else to manage the facility. You can find somebody else to worry about the budget and the money and all of that, but...the instructional piece... [is] the most important part.

Principal B stated that instructional leadership "has a tremendous impact" on teaching and learning in her school, and that her leadership "has kept us from being under the water." On working with specific students over the years, she commented:

That piece of being an administrator is incredible, because those are the things you're going to remember when you retire. You're not going to remember how many times the SOL test changed, but you're going to remember the difference that you made in somebody's life, and they're going to remember it.

Principal C spoke of her impact on the teachers and the quality of their instructional performance, "They work all the time.... For the most part they are working hard and making sure they are doing what they need to do to make the children be successful." All of the principals felt that instructional leadership had the potential to make a tremendous impact on teacher quality and student performance. When asked where they would rate instructional leadership in their list of priorities, the responses were:

- "It's the most important thing that you can do" (Principal A)

- "Right up at the top" (Principal B)

- "Honestly, I think that having a school environment where students are quiet and focused to learning is a necessity. Discipline is therefore my number one priority, and sharing ideas to improve teaching is number two" (Principal C) 
These responses acknowledge the critical role that each of these school leaders believe their instructional leadership plays in the teaching and learning that goes on in their schools.

Summary of themes of principal espoused theory. The principals in this study hold instructional leadership in high esteem. The espoused theory related to instructional leadership expressed by each school leader was quite positive and included a range of activities and tasks. They believe that knowledge is a critical aspect of instructional leadership, as they must be well-versed in effective teaching and instructional strategies across all of the grade levels in their building. Beyond the required level of knowledge, they must act as an encourager and a support to teachers, helping them to progress and improve their professional capacity to meet student learning needs. Although these principals are the only formal leaders in each of their schools, they strive to create cultures of collaboration so that they are working together with teachers and sharing resources for the benefit of all. They acknowledge the need for instructional leaders to take an active role in student progress monitoring as students move through the curriculum to ensure that their individual learning needs are met and that students do not fall through the cracks. The school leaders in this study believe in the importance of being highly visible to students and teachers in the school through formal and informal means, and using their presence to further their ability to influence teacher professional growth. Finally, all of the principals emphasized the tremendous, positive impact that they believed instructional leadership can have on teachers and students. 


\section{Principal Espoused Theory and the Instructional Leadership Research Base}

After engaging in inductive coding procedures to reveal the themes of principal espoused theory described above, I coded the data deductively by comparing it to the research base and mapping it to the PIMRS Framework found earlier in this document and also as Appendix B (Hallinger \& Murphy, 1985). I identified the research-based instructional leadership tasks that each principal referred to during her interview as well as those that she did not mention when discussing instructional leadership.

School A. Table 9 on the next page shows the frequency with which Principal A mentioned tasks associated with each of the PIMRS domains during her interview. At some point during data collection, the principal referred to nine of the ten domains, neglecting only to discuss tasks related to protecting instructional time. Of the nine domains that the leader mentioned, five of them were only referred to once; these five domains were related to school goals, providing incentives, and visibility. The principal referred to tasks included in the remaining four PIMRS domains no less than three, and up to seven, times during her interview. These four domains included tasks related to professional development, curriculum, instructional supervision, and progress monitoring. 
Table 9

School A: Espoused Theory Compared to Research Base

\begin{tabular}{|l|c|}
\hline \multicolumn{1}{|c|}{$\begin{array}{c}\text { PIMRS Domain } \\
\text { (Hallinger \& Murphy, 1985) }\end{array}$} & $\begin{array}{c}\text { Frequency of } \\
\text { Task Mentioned } \\
\text { During Interview }\end{array}$ \\
\hline Frames the School's Goals & 1 \\
\hline Communicates the School's Goals & 1 \\
\hline Coordinates the Curriculum & 3 \\
\hline Supervises \& Evaluates Instruction & 5 \\
\hline Monitors Student Progress & 7 \\
\hline Protects Instructional Time & 0 \\
\hline Provides Incentives for Teachers & 1 \\
\hline Provides Incentives for Learning & 1 \\
\hline Promotes Professional Development & 3 \\
\hline Maintains High Visibility & 1 \\
\hline
\end{tabular}

These data indicate that Principal A's espoused theory of instructional leadership primarily focuses on managing the school's instructional program. Tasks related to coordinating the curriculum, supervising and evaluating instruction, and monitoring student progress are critical to this principal's beliefs about effective instructional leadership. She also focuses on promoting professional development, which is closely tied to the quality of the school instructional program.

Primary gaps in Principal A's espoused theory and the research base are related to protecting instructional time, providing incentives for teachers and for student learning, and framing and communicating the school goals. The researcher does not assume that these things do not necessarily occur in School A, but they were not emphasized by the principal during the interview when she was asked to describe her instructional leadership behaviors and tasks. 
School B. Principal B emphasized similar aspects of instructional leadership during her interview. Table 10 below shows the frequency with which she mentioned tasks associated with the PIMRS domains.

Table 10

School B: Espoused Theory Compared to Research Base

\begin{tabular}{|l|c|}
\hline \multicolumn{1}{|c|}{$\begin{array}{c}\text { PIMRS Domain } \\
\text { (Hallinger \& Murphy, 1985) }\end{array}$} & $\begin{array}{c}\text { Frequency of } \\
\text { Task Mentioned } \\
\text { During Interview }\end{array}$ \\
\hline Frames the School's Goals & 1 \\
\hline Communicates the School's Goals & 1 \\
\hline Coordinates the Curriculum & 3 \\
\hline Supervises \& Evaluates Instruction & 8 \\
\hline Monitors Student Progress & 1 \\
\hline Protects Instructional Time & 0 \\
\hline Provides Incentives for Teachers & 1 \\
\hline Provides Incentives for Learning & 1 \\
\hline Promotes Professional Development & 0 \\
\hline Maintains High Visibility & \\
\hline
\end{tabular}

Of the ten domains, Principal B referred to eight of them during her interview, neglecting only to mention providing incentives for teachers and providing incentives for learning. Of the remaining eight domains that were mentioned, those related to professional development, protecting instructional time, and communicating school goals were only mentioned one time. Principal B most frequently mentioned instructional leadership tasks related to curriculum, supervising instruction, and monitoring student progress. 
These data indicate that the leader of School B believes that instructional leadership centers upon sound management of the school's instructional program. She believes she is engaging in instructional leadership when she works with curriculum, supervises and evaluates classroom instruction, and engages in student progress monitoring. Additionally, these beliefs about what tasks constitute instructional leadership appear to mirror those of Principal A. Once again, the primary gaps between Principal B's espoused theory of instructional leadership and the research base are in the following areas: providing incentives for teachers and for learning, communicating and framing the school goals, protecting instructional time, and promoting professional development.

School C. The principal of School C holds an espoused theory of instructional leadership quite similar to that of Principal A and Principal B. As seen in Table 11 on the next page, the tasks that Principal $\mathrm{C}$ primarily associates with instructional leadership are also related to developing and managing a strong instructional program in the school by coordinating curriculum, supervising and evaluating teachers, and monitoring student progress. The only PIMRS domains that were not explicitly mentioned or implied by Principal $\mathrm{C}$ were protects instructional time, provides incentives for teachers, and provides incentives for learning. 
Table 11

School C: Espoused Theory Compared to Research Base

\begin{tabular}{|l|c|}
\hline \multicolumn{1}{|c|}{$\begin{array}{c}\text { PIMRS Domain } \\
\text { (Hallinger \& Murphy, 1985) }\end{array}$} & $\begin{array}{c}\text { Frequency of } \\
\text { Task Mentioned } \\
\text { During Interview }\end{array}$ \\
\hline Frames the School's Goals & 2 \\
\hline Communicates the School's Goals & 1 \\
\hline Coordinates the Curriculum & 6 \\
\hline Supervises \& Evaluates Instruction & 8 \\
\hline Monitors Student Progress & 7 \\
\hline Protects Instructional Time & 0 \\
\hline Provides Incentives for Teachers & 0 \\
\hline Provides Incentives for Learning & 0 \\
\hline Promotes Professional Development & 3 \\
\hline Maintains High Visibility & 1 \\
\hline
\end{tabular}

Principal espoused theory across school settings. The espoused theories of instructional leadership held by Principal A, B, and C appear to be very closely linked. All of the school leaders participating in this study focused their definitions of instructional leadership around tasks directly related to the school instructional program. Issues involving curriculum, supervision and evaluation of teaching, and monitoring student progress were at the forefront of principal beliefs about their work as instructional leaders. It is also noteworthy that all three of the principals failed to emphasize the same PIMRS domains, which included providing incentives for teachers and for student learning and protecting instructional time. Table 12, shown on the next page, summarizes the frequency with which the school leaders in this study referred to research-based instructional leadership tasks when interviewed about their beliefs about what constitutes 
instructional leadership.

Table 12

Espoused Theory Across School Settings

\begin{tabular}{|l|c|}
\hline \multicolumn{1}{|c|}{$\begin{array}{c}\text { PIMRS Domain } \\
\text { (Hallinger \& Murphy, 1985) }\end{array}$} & $\begin{array}{c}\text { Total Frequency of } \\
\text { Task Mentioned } \\
\text { During Interviews }\end{array}$ \\
\hline Frames the School's Goals & 4 \\
\hline Communicates the School's Goals & 3 \\
\hline Coordinates the Curriculum & 12 \\
\hline Supervises \& Evaluates Instruction & 20 \\
\hline Monitors Student Progress & 22 \\
\hline Protects Instructional Time & 1 \\
\hline Provides Incentives for Teachers & 1 \\
\hline Provides Incentives for Learning & 7 \\
\hline Promotes Professional Development & 3 \\
\hline Maintains High Visibility & 1 \\
\hline
\end{tabular}

It is clear that all of the school leaders in this study referred most frequently to activities related to managing the instructional program. Some of the tasks related to coordinating the curriculum included creating a daily "instructional remediation and enrichment period," "providing the resources to support teachers in core areas," and "revamping instruction as needed based on student achievement the previous school year." The principals spoke of supervising and evaluating instruction both formally and informally. Principal A remarked, "I tell teachers that I'm not coming in the classroom to 'get you.' I want to look at what you're doing, and if I can offer some suggestions... then I will do that. It's a means of support..." Principal B described her work in this area as, "Mentoring, supporting, providing the resources, being a cheerleader, [and] listening." 
Progress monitoring was a third function that received major emphasis from each principal. Principal B stated, "So therefore my priority is...being sure that every child is getting what they need to be successful and they're moving forward and not staying still or moving backwards." She does this through weekly data meetings with teachers where they share student performance data. Principals $\mathrm{A}$ and $\mathrm{C}$ also engage frequently in progress monitoring through a hands-on approach with the students. Principal C noted, I'm also checking students' work, literally, papers. They have to show me tests... so that I can make sure that they are on target and where they need to be." The examples above are just a few of the variety of tasks the principals associated with managing the instructional program. Based on the prevalence of these tasks, it is clear that the actions associated with this domain are at the center of each school leader's espoused theory of instructional leadership.

\section{Principal Theory-In-Use of Instructional Leadership}

While the first phase of data collection in this project collected information about principal beliefs and espoused theory of instructional leadership, the second phase attempted to uncover principal implementation, or theory-in-use, of instructional leadership as perceived by three distinct data sources: the school principal, instructional staff members, and each principal's direct supervisor. Participants completed the PIMRS instrument to rate the frequency with which the principal engaged in fifty specific, research-based instructional leadership behaviors. In this section of the paper, I will summarize the results of the instrument and share relevant findings from each school site as well as across school settings.

School A. At School A, 14 of 21 instructional personnel completed the PIMRS 
instrument, with a response rate totaling $67 \%$. The majority of respondents $(78 \%)$ indicated that they had worked with the current principal for 5-9 years or more. This duration of interaction between the building principal and instructional staff strengthened the validity of survey results. Unfortunately, the principal's supervisor was new to the supervisory role during the 2013-2014 academic year and had worked with the principal for less than one year in that capacity; therefore, the supervisor had less frequent opportunities to observe the principal's instructional leadership behaviors at the time the survey was administered.

Defining the school mission. The first ten PIMRS items were behavior statements related to the principal's instructional leadership behaviors that contribute to defining the school mission by framing and communicating the school goals. Earlier in this paper, I concluded that Principal A's espoused theory of instructional leadership did not focus on or emphasize these types of behaviors. In fact, these behaviors were among those discussed the least by Principal A when talking with her about her beliefs about her role as an instructional leader--only $9 \%$ of the specific tasks that Principal A mentioned during her interview were classified as defining the school mission.

In contrast to the lack of emphasis on goal-framing and goal-communicating tasks during the qualitative data collection during this study, Principal A rated herself as performing $100 \%$ of the associated tasks "frequently" or "almost always," as did her supervisor. Teachers also perceived that Principal A engaged in these tasks often as part of her instructional leadership work, with the average teacher rating her as performing these tasks "frequently" or "almost always" $80 \%$ of the time.

Only two behaviors related to defining the school mission through framing and 
communicating the school goals to stakeholders yielded a mean and mode of 3 ("sometimes") or lower from participating teachers. These two areas, ensuring that school goals are reflected through visible displays and referring to school goals in forums with students, were also those with the lowest principal and supervisor summed scores. Table 13 below shows the teacher, principal, and supervisor results for this domain of the PIMRS instrument. These data indicate that Principal A does indeed engage frequently in behaviors related to communicating and framing school goals as part of her implementation of instructional leadership at School B. Therefore, her theory-in-use of instructional leadership emphasizes defining the school's vision and mission more so than her espoused theory.

Table 13

School A PIMRS Results: Defining the School Mission

\begin{tabular}{|l|c|c|c|c|}
\hline \multicolumn{1}{|c|}{ PIMRS Instructional Leadership Behavior } & $\begin{array}{c}\text { Teacher } \\
\text { Mean }\end{array}$ & $\begin{array}{c}\text { Teacher } \\
\text { Mode }\end{array}$ & Principal & Supervisor \\
\hline Develop a focused set of annual school-wide goals & 4.5 & 5 & 5 & 5 \\
\hline $\begin{array}{l}\text { Frame the school's goals in terms of staff } \\
\text { responsibilities for meeting them }\end{array}$ & 4.6 & 5 & 4 & 5 \\
\hline $\begin{array}{l}\text { Use needs assessment or other formal and informal } \\
\text { methods to secure staff input on goal development }\end{array}$ & 4.4 & 5 & 4 & 5 \\
\hline $\begin{array}{l}\text { Use data on student performance when developing the } \\
\text { school's academic goals }\end{array}$ & 4.7 & 5 & 5 & 5 \\
\hline $\begin{array}{l}\text { Develop goals that are easily understood and used by } \\
\text { teachers in the school }\end{array}$ & 4.1 & 5 & 5 & 5 \\
\hline $\begin{array}{l}\text { Communicate the school's mission effectively to } \\
\text { members of the school community }\end{array}$ & 3.8 & 5 & 4 & 5 \\
\hline $\begin{array}{l}\text { Discuss the school's academic goals with teachers at } \\
\text { faculty meetings }\end{array}$ & 4.4 & 5 & 5 & 5 \\
\hline $\begin{array}{l}\text { Refer to the school's academic goals when making } \\
\text { curricular decisions with teachers }\end{array}$ & 4.2 & 4 & 5 & 4 \\
\hline $\begin{array}{l}\text { Ensure that the school's academic goals are reflected } \\
\text { in highly visible displays in the school (e.g. posters or } \\
\text { bulletin boards emphasizing academic progress) }\end{array}$ & 3.0 & 3 & 4 & 4 \\
\hline $\begin{array}{l}\text { Refer to the school's goals or mission in forums with } \\
\text { students (e.g. in assemblies or discussions) }\end{array}$ & 2.5 & 2 & 4 & 5 \\
\hline
\end{tabular}

Note that a score of $1=$ Almost Never, $5=$ Almost Always 
Managing the instructional program. The fifteen PIMRS items included in this domain encompass behaviors related to coordinating the curriculum, supervising and evaluating instruction, and monitoring student progress. All three of the principals in this study hold espoused theories of instructional leadership that strongly emphasize these types of tasks. Principal A referred to these behaviors more often than any other type of instructional leadership task when discussing her views about effective instructional leadership. $65 \%$ of the specific tasks that she mentioned when defining her role as an instructional leader were classified in this PIMRS domain. Table 14, shown in its entirety on the next page, shares results of the PIMRS from each data source related to Principal A's management of the school instructional program. 
Table 14

School A PIMRS Results: Managing the Instructional Program

\begin{tabular}{|c|c|c|c|c|}
\hline PIMRS Instructional Leadership Behavior & $\begin{array}{c}\text { Teacher } \\
\text { Mean }\end{array}$ & $\begin{array}{c}\text { Teacher } \\
\text { Mode }\end{array}$ & Principal & Supervisor \\
\hline $\begin{array}{l}\text { Ensure that the classroom priorities of teachers are } \\
\text { consistent with the goals and direction of the school }\end{array}$ & 4 & 4 & 5 & 5 \\
\hline $\begin{array}{l}\text { Review student work products when evaluating } \\
\text { classroom instruction }\end{array}$ & 2.9 & 3 & 5 & 5 \\
\hline $\begin{array}{l}\text { Conduct informal observations in classrooms on a } \\
\text { regular basis (informal observations are unscheduled, } \\
\text { last at least } 5 \text { minutes, and may or may not involve } \\
\text { written feedback or a formal conference) }\end{array}$ & 3.3 & 3 & 5 & 5 \\
\hline $\begin{array}{l}\text { Point out specific strengths in teacher's instructional } \\
\text { practices in post-observation feedback (e.g., in } \\
\text { conferences or written evaluations) }\end{array}$ & 3 & 3 & 5 & 5 \\
\hline $\begin{array}{l}\text { Point out specific weaknesses in teacher instructional } \\
\text { practices in post-observation feedback (e.g., in } \\
\text { conferences or written evaluations) }\end{array}$ & 3.6 & 3 & 5 & 5 \\
\hline $\begin{array}{l}\text { Make clear who is responsible for coordinating the } \\
\text { curriculum across grade levels (e.g., the principal, vice } \\
\text { principal, or teacher-leader) }\end{array}$ & 3.7 & 5 & 5 & 5 \\
\hline $\begin{array}{l}\text { Draw upon the results of school-wide testing when } \\
\text { making curricular decisions }\end{array}$ & 4.6 & 5 & 5 & 5 \\
\hline $\begin{array}{l}\text { Monitor the classroom curriculum to see that it covers } \\
\text { the school's curricular objectives }\end{array}$ & 4.2 & 5 & 5 & 5 \\
\hline $\begin{array}{l}\text { Assess the overlap between the school's curricular } \\
\text { objectives and the school's achievement tests }\end{array}$ & 4.3 & 5 & 5 & 5 \\
\hline $\begin{array}{l}\text { Participate actively in the review of curricular } \\
\text { materials }\end{array}$ & 3.8 & 3 & 5 & 4 \\
\hline $\begin{array}{l}\text { Meet individually with teachers to discuss student } \\
\text { progress }\end{array}$ & 3.7 & 4 & 5 & 5 \\
\hline $\begin{array}{l}\text { Discuss academic performance results with the faculty } \\
\text { to identify curricular strengths and weaknesses }\end{array}$ & 3.8 & 4 & 5 & 5 \\
\hline $\begin{array}{l}\text { Use tests and other performance measures to assess } \\
\text { progress toward school goals }\end{array}$ & 4.4 & 5 & 5 & 5 \\
\hline $\begin{array}{l}\text { Inform teachers of the school's performance results in } \\
\text { written form (e.g., in a memo or newsletter) }\end{array}$ & 3.4 & 4 & 5 & 4 \\
\hline Inform students of school's academic progress & 2.6 & 2 & 5 & 5 \\
\hline
\end{tabular}

Note that a score of $1=$ Almost Never, 5=Almost Always

Principal A and her supervisor rated her performance of instructional management tasks as "almost always" $93 \%$ of the time. Conversely, data from teachers indicates their perception that Principal A engaged in some of these activities on a less frequent basis, 
rating her engagement in these behaviors as "frequently" or "almost always" only $1 / 3$ of the time.

The most significant disagreement, a gap of 3 points between data sources, was found in the area of informing students of school's academic progress. Most teachers rated the principal as doing this activity "seldom" (2) while both of the other sources perceived that it is performed "almost always" (5). Other behaviors with gaps of at least two points between the teacher rating and administrator/supervisor rating included: reviewing student work products during evaluations, conducting informal classroom observations, pointing out specific strengths and weaknesses in classroom instruction, and participating in the review of curricular materials. Most of the behaviors with large gaps between ratings amongst the three data sources were associated with supervision and evaluation of classroom instruction. While Principal A's espoused theory of instructional leadership heavily emphasizes instructional management activities, some aspects of her theory-in-use (implementation) of these behaviors, as perceived by teachers and particularly related to supervision and evaluation of classroom instruction, are incongruent with her espoused beliefs.

Developing the school learning climate. The twenty-five behaviors included in this domain of the PIMRS include those associated with the following functions: protects instructional time, provides incentives for teachers, provides incentives for learning, promotes professional development, and maintains high visibility. The espoused theory expressed by Principal A during qualitative data collection did not focus a great deal on any of these behaviors, but she emphasized professional development more than the other areas. Table 15, shown on the following two pages, shows results of the PIMRS from 
each of the data sources related to Principal A's work in developing the school learning climate.

Table 15

School A PIMRS Results: Developing the School Learning Climate

\begin{tabular}{|c|c|c|c|c|}
\hline PIMRS Instructional Leadership Behavior & $\begin{array}{l}\text { Teacher } \\
\text { Mean }\end{array}$ & $\begin{array}{l}\text { Teacher } \\
\text { Mode }\end{array}$ & Principal & Supervisor \\
\hline $\begin{array}{l}\text { Limit interruptions of instructional time by public } \\
\text { address announcements }\end{array}$ & 4.6 & 5 & 5 & 5 \\
\hline $\begin{array}{l}\text { Ensure that students are not called to the office during } \\
\text { instructional time }\end{array}$ & 4.2 & 5 & 5 & 4 \\
\hline $\begin{array}{l}\text { Ensure that tardy and truant students suffer specific } \\
\text { consequences for missing instructional time }\end{array}$ & 2.1 & 2 & 4 & 5 \\
\hline $\begin{array}{l}\text { Encourage teachers to use instructional time for } \\
\text { teaching and practicing new skills and concepts }\end{array}$ & 4.9 & 5 & 5 & 5 \\
\hline $\begin{array}{l}\text { Limit the intrusion of extra- and co-curricular } \\
\text { activities on instructional time }\end{array}$ & 4.5 & 5 & 5 & 4 \\
\hline $\begin{array}{l}\text { Take time to talk informally with students and } \\
\text { teachers during recess and breaks }\end{array}$ & 2.4 & 2 & 5 & 4 \\
\hline $\begin{array}{l}\text { Visit classrooms to discuss school issues with teachers } \\
\text { and students }\end{array}$ & 2.9 & 3 & 4 & 5 \\
\hline Attend/participate in extra- and co-curricular activities & 3.3 & 2 & 4 & 5 \\
\hline $\begin{array}{l}\text { Cover classes for teachers until a late or substitute } \\
\text { teacher arrives }\end{array}$ & 1.9 & 1 & 3 & 3 \\
\hline Tutor students or provide direct instruction to classes & 1.4 & 1 & 3 & 3 \\
\hline $\begin{array}{l}\text { Reinforce superior performance by teachers in staff } \\
\text { meetings, newsletters, and/or memos }\end{array}$ & 2.4 & 3 & 5 & 5 \\
\hline $\begin{array}{l}\text { Compliment teachers privately for their efforts or } \\
\text { performance }\end{array}$ & 2.4 & 2 & 5 & 5 \\
\hline $\begin{array}{l}\text { Acknowledge teachers' exceptional performance by } \\
\text { writing memos for their personnel files }\end{array}$ & 2 & 1 & 3 & 3 \\
\hline $\begin{array}{l}\text { Reward special efforts by teachers with opportunities } \\
\text { for professional recognition }\end{array}$ & 2.3 & 3 & 5 & 4 \\
\hline $\begin{array}{l}\text { Create professional growth opportunities for teachers } \\
\text { as a reward for special contributions to the school }\end{array}$ & 2.5 & 1 & 4 & 3 \\
\hline $\begin{array}{l}\text { Ensure that inservice activities attended by staff are } \\
\text { consistent with the school's goals }\end{array}$ & 4 & 4 & 5 & 5 \\
\hline $\begin{array}{l}\text { Actively support the use in the classroom of skills } \\
\text { acquired during inservice training }\end{array}$ & 4 & 4 & 5 & 5 \\
\hline $\begin{array}{l}\text { Obtain the participation of the whole staff in important } \\
\text { inservice activities }\end{array}$ & 3.9 & 5 & 5 & 5 \\
\hline
\end{tabular}




\begin{tabular}{|l|c|c|c|c|}
\hline \multicolumn{1}{|c|}{ PIMRS Instructional Leadership Behavior } & $\begin{array}{c}\text { Teacher } \\
\text { Mean }\end{array}$ & $\begin{array}{c}\text { Teacher } \\
\text { Mode }\end{array}$ & Principal & Supervisor \\
\hline $\begin{array}{l}\text { Lead or attend teacher inservice activities concerned } \\
\text { with instruction }\end{array}$ & 4.1 & 5 & 5 & 4 \\
\hline $\begin{array}{l}\text { Set aside time at faculty meetings for teachers to share } \\
\text { ideas or information from inservice }\end{array}$ & 4.3 & 5 & 5 & 5 \\
\hline $\begin{array}{l}\text { Recognize students who do superior work with formal } \\
\text { rewards such as an honor roll or mention in the } \\
\text { principal's newsletter }\end{array}$ & 3.8 & 3 & 5 & 5 \\
\hline $\begin{array}{l}\text { Use assemblies to honor students for academic } \\
\text { accomplishments or for behavior or citizenship }\end{array}$ & 2.3 & 1 & 5 & 5 \\
\hline $\begin{array}{l}\text { Recognize superior student achievement or } \\
\text { improvement by seeing in the office students with } \\
\text { their work }\end{array}$ & 2 & 1 & 4 & 5 \\
\hline $\begin{array}{l}\text { Contact parents to communicate improved or } \\
\text { exemplary student performance or contributions }\end{array}$ & 1.8 & 1 & 5 & 5 \\
\hline $\begin{array}{l}\text { Support teachers actively in their recognition and/or } \\
\text { reward of student contributions to and } \\
\text { accomplishments in class }\end{array}$ & 3.1 & 3 & 5 & 5 \\
\hline
\end{tabular}

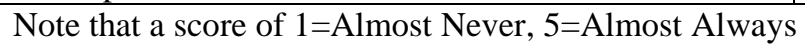

PIMRS results for this domain show the greatest disparity between the principal/supervisor ratings and the teacher ratings of the principal's instructional leadership work. Principal A rated herself as engaging in these behaviors "frequently" or "almost always" $88 \%$ of the time, and her supervisor rated her at that level $84 \%$ of the time. On the contrary, the average teacher rating of Principal A's instructional leadership in this domain was at the level of "frequently" or higher only $32 \%$ of the time.

These results indicate that there is a disconnect between teacher and principal/supervisor views of Principal A's instructional leadership related to developing the school learning climate. Nearly $50 \%$ of the behavioral items in this section of the PIMRS resulted in a difference of at least two points between the teacher mean and mode and the principal self-rating. Many of the behaviors with the greatest disparity in ratings were those related to providing incentives for teachers and providing incentives for learning. These same areas also received very little emphasis during qualitative data 
collection when gathering information about Principal A's espoused theory of instructional leadership and its associated tasks. Although developing the school learning climate comprises $50 \%$ of the PIMRS framework and behavioral items, only $26 \%$ of the specific instructional leadership tasks mentioned by Principal A during qualitative data collection were associated with this domain. These data indicate that Principal A does not emphasize developing the school learning climate as part of her espoused theory (beliefs) or her theory-in-use (implementation) of instructional leadership.

School B. At School B, 17 of 26 instructional personnel completed the PIMRS instrument, with a response rate totaling $65 \%$. The majority of respondents $(82 \%)$ indicated that they had worked with the building principal for 5-9 years or more. While this led to a high duration of interaction between the principal and teachers at the time the survey was administered, the division Director of Elementary Education, once again, had been working with the principal in a supervisory capacity for slightly less than one year at the time that the PIMRS was administered.

Defining the school mission. The first ten PIMRS items were behavior statements related to the principal's instructional leadership behaviors that contribute to defining the school mission by framing and communicating the school goals. Earlier in this paper, I concluded that Principal B's espoused theory of instructional leadership did not focus on or emphasize these types of instructional leadership behaviors. In fact, just as was the case with Principal A, these behaviors related to school goals were among those mentioned the least by Principal B when discussing her beliefs about her role as an instructional leader--only $8 \%$ of the specific tasks discussed by Principal B were classified in this domain of the PIMRS framework. 
Although Principal B did not emphasize behaviors related to defining the school mission as part of her espoused theory, she rated herself as performing $100 \%$ of the associated tasks "almost always." Her supervisor also perceived that she performed each of these tasks "almost always" or "frequently." Only three of the behaviors associated with this PIMRS domain yielded both a mean and mode score that was below 3.5 ("frequently") from teachers: communicating the school's mission to the school community, reflecting the school's academic goals in visible displays, and referring to school goals in forums with students. Those same three behaviors also received the lowest teacher averages for Principal A. Even though teachers rated these three behaviors as occurring less frequently, the principal and supervisor scores for these behaviors did not indicate that they occurred less often than other behaviors included in this domain.

The data from each source, included in Table 16 shown in its entirety on the following page, indicate that Principal B's theory-in-use, and thereby implementation, of instructional leadership does include frequent behaviors that relate to framing and communicating the school goals. 
Table 16

School B PIMRS Results: Defining the School Mission

\begin{tabular}{|l|c|c|c|c|}
\hline \multicolumn{1}{|c|}{ PIMRS Instructional Leadership Behavior } & $\begin{array}{c}\text { Teacher } \\
\text { Mean }\end{array}$ & $\begin{array}{c}\text { Teacher } \\
\text { Mode }\end{array}$ & Principal & Supervisor \\
\hline Develop a focused set of annual school-wide goals & 3.9 & 5 & 5 & 5 \\
\hline $\begin{array}{l}\text { Frame the school's goals in terms of staff } \\
\text { responsibilities for meeting them }\end{array}$ & 4.1 & 5 & 5 & 5 \\
\hline $\begin{array}{l}\text { Use needs assessment or other formal and informal } \\
\text { methods to secure staff input on goal development }\end{array}$ & 3.6 & 3 & 5 & 4 \\
\hline $\begin{array}{l}\text { Use data on student performance when developing the } \\
\text { school's academic goals }\end{array}$ & 4.5 & 5 & 5 & 5 \\
\hline $\begin{array}{l}\text { Develop goals that are easily understood and used by } \\
\text { teachers in the school }\end{array}$ & 4.1 & 4 & 5 & 5 \\
\hline $\begin{array}{l}\text { Communicate the school's mission effectively to } \\
\text { members of the school community }\end{array}$ & 3.4 & 2 & 5 & 5 \\
\hline $\begin{array}{l}\text { Discuss the school's academic goals with teachers at } \\
\text { faculty meetings }\end{array}$ & 4.2 & 5 & 5 & 5 \\
\hline $\begin{array}{l}\text { Refer to the school's academic goals when making } \\
\text { curricular decisions with teachers }\end{array}$ & 4.1 & 5 & 5 & 4 \\
\hline $\begin{array}{l}\text { Ensure that the school's academic goals are reflected } \\
\text { in highly visible displays in the school (e.g. posters or } \\
\text { bulletin boards emphasizing academic progress) }\end{array}$ & 3.2 & 3 & 5 & 4 \\
\hline $\begin{array}{l}\text { Refer to the school's goals or mission in forums with } \\
\text { students (e.g. in assemblies or discussions) }\end{array}$ & 2.8 & 2 & 5 & 4 \\
\hline
\end{tabular}

Note that a score of $1=$ Almost Never, $5=$ Almost Always

Managing the instructional program. The fifteen PIMRS items included in this domain encompass behaviors related to coordinating the curriculum, supervising and evaluating instruction, and monitoring student progress. All three of the principals in this study hold espoused theories of instructional leadership that emphasize these types of tasks. Like Principal A, Principal B referred to these behaviors more often than any other type of instructional leadership task when discussing her views about effective instructional leadership-75\% of the specific tasks Principal B mentioned during qualitative data collection were classified under this PIMRS domain. 
Table 17 below shows results of the PIMRS from each data source related to

Principal B's management of the school instructional program.

Table 17

School B PIMRS Results: Managing the Instructional Program

\begin{tabular}{|c|c|c|c|c|}
\hline PIMRS Instructional Leadership Behavior & $\begin{array}{l}\text { Teacher } \\
\text { Mean }\end{array}$ & $\begin{array}{l}\text { Teacher } \\
\text { Mode }\end{array}$ & Principal & Supervisor \\
\hline $\begin{array}{l}\text { Ensure that the classroom priorities of teachers are } \\
\text { consistent with the goals and direction of the school }\end{array}$ & 3.8 & 4 & 5 & 5 \\
\hline $\begin{array}{l}\text { Review student work products when evaluating } \\
\text { classroom instruction }\end{array}$ & 3.6 & 4 & 5 & 4 \\
\hline $\begin{array}{l}\text { Conduct informal observations in classrooms on a } \\
\text { regular basis (informal observations are unscheduled, } \\
\text { last at least } 5 \text { minutes, and may or may not involve } \\
\text { written feedback or a formal conference) }\end{array}$ & 3.3 & 3 & 5 & 4 \\
\hline $\begin{array}{l}\text { Point out specific strengths in teacher's instructional } \\
\text { practices in post-observation feedback (e.g., in } \\
\text { conferences or written evaluations) }\end{array}$ & 3.5 & 3 & 5 & 5 \\
\hline $\begin{array}{l}\text { Point out specific weaknesses in teacher instructional } \\
\text { practices in post-observation feedback (e.g., in } \\
\text { conferences or written evaluations) }\end{array}$ & 3.4 & 3 & 5 & 5 \\
\hline $\begin{array}{l}\text { Make clear who is responsible for coordinating the } \\
\text { curriculum across grade levels (e.g., the principal, vice } \\
\text { principal, or teacher-leader) }\end{array}$ & 4.1 & 4 & 5 & 5 \\
\hline $\begin{array}{l}\text { Draw upon the results of school-wide testing when } \\
\text { making curricular decisions }\end{array}$ & 4.3 & 4 & 5 & 5 \\
\hline $\begin{array}{l}\text { Monitor the classroom curriculum to see that it covers } \\
\text { the school's curricular objectives }\end{array}$ & 3.8 & 5 & 5 & 5 \\
\hline $\begin{array}{l}\text { Assess the overlap between the school's curricular } \\
\text { objectives and the school's achievement tests }\end{array}$ & 4.1 & 5 & 5 & 4 \\
\hline $\begin{array}{l}\text { Participate actively in the review of curricular } \\
\text { materials }\end{array}$ & 3.7 & 4 & 5 & 4 \\
\hline $\begin{array}{l}\text { Meet individually with teachers to discuss student } \\
\text { progress }\end{array}$ & 3.7 & 3 & 5 & 5 \\
\hline $\begin{array}{l}\text { Discuss academic performance results with the faculty } \\
\text { to identify curricular strengths and weaknesses }\end{array}$ & 4.1 & 5 & 5 & 5 \\
\hline $\begin{array}{l}\text { Use tests and other performance measures to assess } \\
\text { progress toward school goals }\end{array}$ & 4.2 & 5 & 5 & 5 \\
\hline $\begin{array}{l}\text { Inform teachers of the school's performance results in } \\
\text { written form (e.g., in a memo or newsletter) }\end{array}$ & 4.1 & 5 & 5 & 5 \\
\hline Inform students of school's academic progress & 3.2 & 3 & 5 & 4 \\
\hline
\end{tabular}

Note that a score of $1=$ Almost Never, 5=Almost Always 
These survey results indicate that Principal B believes that she performs all of these instructional management activities "almost always." Her supervisor indicated that she performed $2 / 3$ of the activities "almost always" and the remaining $1 / 3$ of them "frequently." As was the case with Principal A, teacher data indicated disagreement with the principal and supervisor perspective in several areas. There was a difference of two points between most teacher respondents and the principal response in the following areas: conducting regular, informal classroom observations; pointing out specific strengths and weaknesses in classroom instruction; meeting individually with students to discuss student progress, and; informing students of school's academic progress.

As was the case with School A, the instructional leadership behaviors that received the lowest frequency rating from teachers at School B were primarily those related to supervision and evaluation of instruction. Conversely, Principal B's espoused theory of instructional leadership heavily emphasized instructional management behaviors, particularly as it related to supervision and evaluation of instruction. These data indicate that some aspects of Principal B's theory-in-use (implementation) of instructional management behaviors, as perceived by teachers, do not align with her espoused theory/beliefs about instructional leadership.

Developing the school learning climate. The twenty-five behaviors included in this domain of the PIMRS include those associated with the following functions: protects instructional time, provides incentives for teachers, provides incentives for learning, promotes professional development, and maintains high visibility. The espoused theory expressed by Principal B during qualitative data collection did not focus a great deal on any of these behaviors - only $17 \%$ of the specific tasks mentioned by Principal B were 
classified under this domain — but she emphasized maintaining visibility more than the other areas.

Table 18, shown below and on the following page, shares results of the PIMRS from each data source related to Principal B's work in developing the school learning climate.

Table 18

School B PIMRS Results: Developing the School Learning Climate

\begin{tabular}{|l|c|c|c|c|}
\hline \multicolumn{1}{|c|}{ PIMRS Instructional Leadership Behavior } & $\begin{array}{c}\text { Teacher } \\
\text { Mean }\end{array}$ & $\begin{array}{c}\text { Teacher } \\
\text { Mode }\end{array}$ & Principal & Supervisor \\
\hline $\begin{array}{l}\text { Limit interruptions of instructional time by public } \\
\text { address announcements }\end{array}$ & 4.4 & 5 & 5 & 4 \\
\hline $\begin{array}{l}\text { Ensure that students are not called to the office during } \\
\text { instructional time }\end{array}$ & 3.9 & 4 & 5 & 5 \\
\hline $\begin{array}{l}\text { Ensure that tardy and truant students suffer specific } \\
\text { consequences for missing instructional time }\end{array}$ & 2.7 & 3 & 5 & 5 \\
\hline $\begin{array}{l}\text { Encourage teachers to use instructional time for } \\
\text { teaching and practicing new skills and concepts }\end{array}$ & 4.6 & 5 & 5 & 5 \\
\hline $\begin{array}{l}\text { Limit the intrusion of extra- and co-curricular } \\
\text { activities on instructional time }\end{array}$ & 4.1 & 5 & 5 & 4 \\
\hline $\begin{array}{l}\text { Take time to talk informally with students and } \\
\text { teachers during recess and breaks }\end{array}$ & 3.6 & 3 & 5 & 5 \\
\hline $\begin{array}{l}\text { Visit classrooms to discuss school issues with teachers } \\
\text { and students }\end{array}$ & 3.3 & 3 & 5 & 5 \\
\hline Attend/participate in extra- and co-curricular activities & 3.9 & 5 & 5 & 3 \\
\hline $\begin{array}{l}\text { Cover classes for teachers until a late or substitute } \\
\text { teacher arrives }\end{array}$ & 2.4 & 2 & 5 & 4 \\
\hline Tutor students or provide direct instruction to classes & 2.4 & 2 & 5 & 5 \\
\hline $\begin{array}{l}\text { Reinforce superior performance by teachers in staff } \\
\text { meetings, newsletters, and/or memos }\end{array}$ & 2.9 & 3 & 5 & 5 \\
\hline $\begin{array}{l}\text { Compliment teachers privately for their efforts or } \\
\text { performance }\end{array}$ & 3.4 & 3 & 5 & 5 \\
\hline $\begin{array}{l}\text { Acknowledge teachers' exceptional performance by } \\
\text { writing memos for their personnel files }\end{array}$ & 2.9 & 3 & 5 & 5 \\
\hline $\begin{array}{l}\text { Reward special efforts by teachers with opportunities } \\
\text { for professional recognition }\end{array}$ & 2.8 & 2 & 5 & 5 \\
\hline $\begin{array}{l}\text { Create professional growth opportunities for teachers } \\
\text { as a reward for special contributions to the school }\end{array}$ & 2.7 & 3 & 5 & 5 \\
\hline
\end{tabular}




\begin{tabular}{|l|c|c|c|c|}
\hline \multicolumn{1}{|c|}{ PIMRS Instructional Leadership Behavior } & $\begin{array}{c}\text { Teacher } \\
\text { Mean }\end{array}$ & $\begin{array}{c}\text { Teacher } \\
\text { Mode }\end{array}$ & Principal & Supervisor \\
\hline $\begin{array}{l}\text { Ensure that inservice activities attended by staff are } \\
\text { consistent with the school's goals }\end{array}$ & 3.8 & 3 & 5 & 5 \\
\hline $\begin{array}{l}\text { Actively support the use in the classroom of skills } \\
\text { acquired during inservice training }\end{array}$ & 3.7 & 3 & 5 & 5 \\
\hline $\begin{array}{l}\text { Obtain the participation of the whole staff in important } \\
\text { inservice activities }\end{array}$ & 3.8 & 4 & 5 & 5 \\
\hline $\begin{array}{l}\text { Lead or attend teacher inservice activities concerned } \\
\text { with instruction }\end{array}$ & 3.3 & 4 & 5 & 4 \\
\hline $\begin{array}{l}\text { Set aside time at faculty meetings for teachers to share } \\
\text { ideas or information from inservice }\end{array}$ & 3.7 & 3 & 5 & 5 \\
\hline $\begin{array}{l}\text { Recognize students who do superior work with formal } \\
\text { rewards such as an honor roll or mention in the } \\
\text { principal's newsletter }\end{array}$ & 3.3 & 3 & 5 & 5 \\
\hline $\begin{array}{l}\text { Use assemblies to honor students for academic } \\
\text { accomplishments or for behavior or citizenship }\end{array}$ & 2.9 & 2 & 5 & 5 \\
\hline $\begin{array}{l}\text { Recognize superior student achievement or } \\
\text { improvement by seeing in the office students with } \\
\text { their work }\end{array}$ & 2.7 & 2 & 5 & 5 \\
\hline $\begin{array}{l}\text { Contact parents to communicate improved or } \\
\text { exemplary student performance or contributions }\end{array}$ & 2.8 & 3 & 5 & 5 \\
\hline $\begin{array}{l}\text { Support teachers actively in their recognition and/or } \\
\text { reward of student contributions to and } \\
\text { accomplishments in class }\end{array}$ & 3.4 & 4 & 5 & \\
\hline
\end{tabular}

Note that a score of $1=$ Almost Never, 5=Almost Always

Principal B rated herself as performing these activities related to developing the school climate "almost always" $100 \%$ of the time. Her supervisor also viewed her as frequently engaging in these activities, rating her work "frequently" or "almost always" $84 \%$ of the time. As was the case in School A, a large disparity exists between the supervisor/principal ratings and teacher ratings in this area. Teachers in School B, on average, rated Principal B at the level of "frequently" or "almost always" only $12 \%$ of the time.

It is clear that there is a great amount of disagreement between data sources about the frequency of Principal B's work in developing the school learning climate. Nearly $70 \%$ of the time, there was a difference of two points between the principal self-rating 
and the teacher rating for the behavioral items included in this PIMRS domain. This difference was present for $100 \%$ of the behaviors related to maintaining high visibility and providing incentives for teachers and for $80 \%$ of behaviors related to promoting professional development and providing incentives for learning.

Although the teacher results and principal results were so incongruent, the teacher results were aligned with the views expressed by Principal B during qualitative data collection. When discussing her role as an instructional leader and the associated tasks, she did not mention providing incentives for teachers or for learning. Additionally, only $17 \%$ of the tasks mentioned during qualitative data collection were related to other functions of this PIMRS domain. These results suggest that neither Principal B's espoused theory nor theory-in-use of instructional leadership focuses on developing the school learning climate.

School C. At School C, 17 of 17 instructional personnel completed the PIMRS instrument, with a response rate totaling $100 \%$. The majority of respondents $(76 \%)$ indicated that they had worked with the building principal for 5-9 years or more. The length of the working relationship between the principal and teachers likely strengthened the ability of teachers to answer the survey items and rate the principal's instructional leadership behaviors. However, the principal's supervisor had less than one year of experience working in a direct, supervisory role with the principal before the PIMRS was administered.

Defining the school mission. The first ten PIMRS items were behavior statements related to the principal's instructional leadership behaviors that contribute to defining the school mission by framing and communicating the school goals. Earlier in this paper, I 
concluded that Principal C's espoused theory of instructional leadership did not focus a great deal on these types of instructional leadership behaviors-11\% of the specific instructional leadership tasks mentioned by Principal $\mathrm{C}$ were classified under this domain.

Of the ten behaviors measured in this PIMRS domain, Principal $\mathrm{C}$ rated herself as performing $90 \%$ of the behaviors "frequently" or "almost always"; the tenth behavior received a score of "sometimes." The supervisor data indicated the perception that the principal performed $100 \%$ of the tasks related to framing and communicating school goals "frequently" or "almost always." Teachers in School C also rated the principal very highly. Eighty percent of the tasks had a mode of 5 ("almost always") as perceived by teachers, and only $20 \%$ had an average of less than 4 ("frequently"). The behaviors with the lowest teacher average were as follows: reflecting school academic goals in visible displays, and referring to school goals in forums with students. These are, again, the same behaviors performed least frequently by Principals A and B.

The data from each source, shown in Table 19 on the next page, indicate that Principal C's theory-in-use of instructional leadership includes frequent implementation of tasks related to defining the school's vision and mission by framing and communicating school goals to various stakeholders. 
Table 19

School C PIMRS Results: Defining the School Mission

\begin{tabular}{|l|c|c|c|c|}
\hline \multicolumn{1}{|c|}{ PIMRS Instructional Leadership Behavior } & $\begin{array}{c}\text { Teacher } \\
\text { Mean }\end{array}$ & $\begin{array}{c}\text { Teacher } \\
\text { Mode }\end{array}$ & Principal & Supervisor \\
\hline Develop a focused set of annual school-wide goals & 4.4 & 5 & 5 & 5 \\
\hline $\begin{array}{l}\text { Frame the school's goals in terms of staff } \\
\text { responsibilities for meeting them }\end{array}$ & 4.4 & 5 & 5 & 5 \\
\hline $\begin{array}{l}\text { Use needs assessment or other formal and informal } \\
\text { methods to secure staff input on goal development }\end{array}$ & 4.2 & 5 & 5 & 4 \\
\hline $\begin{array}{l}\text { Use data on student performance when developing the } \\
\text { school's academic goals }\end{array}$ & 4.5 & 5 & 5 & 5 \\
\hline $\begin{array}{l}\text { Develop goals that are easily understood and used by } \\
\text { teachers in the school }\end{array}$ & 4.3 & 5 & 5 & 5 \\
\hline $\begin{array}{l}\text { Communicate the school's mission effectively to } \\
\text { members of the school community }\end{array}$ & 4.3 & 5 & 4 & 5 \\
\hline $\begin{array}{l}\text { Discuss the school's academic goals with teachers at } \\
\text { faculty meetings }\end{array}$ & 4.8 & 5 & 4 & 4 \\
\hline $\begin{array}{l}\text { Refer to the school's academic goals when making } \\
\text { curricular decisions with teachers }\end{array}$ & 4.4 & 5 & 5 & 4 \\
\hline $\begin{array}{l}\text { Ensure that the school's academic goals are reflected } \\
\text { in highly visible displays in the school (e.g. posters or } \\
\text { bulletin boards emphasizing academic progress) }\end{array}$ & 3.3 & 3 & 3 & 4 \\
\hline $\begin{array}{l}\text { Refer to the school's goals or mission in forums with } \\
\text { students (e.g. in assemblies or discussions) }\end{array}$ & 3.8 & 4 & 5 & \\
\hline
\end{tabular}

Note that a score of $1=$ Almost Never, $5=$ Almost Always

Managing the instructional program. The fifteen PIMRS items included in this domain encompass behaviors related to coordinating the curriculum, supervising and evaluating instruction, and monitoring student progress. All three of the principals in this study hold espoused theories of instructional leadership that emphasize these types of tasks. Like Principals A and B, Principal C referred to these behaviors more often than any other type of instructional leadership task when discussing her views about effective instructional leadership $-75 \%$ of the specific instructional leadership tasks that she described were classified under this domain. Table 20, shown on the next page, shares 
results of the PIMRS from each data source related to Principal C's management of the school instructional program.

Table 20

School C PIMRS Results: Managing the Instructional Program

\begin{tabular}{|c|c|c|c|c|}
\hline PIMRS Instructional Leadership Behavior & $\begin{array}{c}\text { Teacher } \\
\text { Mean }\end{array}$ & $\begin{array}{c}\text { Teacher } \\
\text { Mode }\end{array}$ & Principal & Supervisor \\
\hline $\begin{array}{l}\text { Ensure that the classroom priorities of teachers are } \\
\text { consistent with the goals and direction of the school }\end{array}$ & 4.5 & 5 & 4 & 4 \\
\hline $\begin{array}{l}\text { Review student work products when evaluating } \\
\text { classroom instruction }\end{array}$ & 3.9 & 5 & 4 & 4 \\
\hline $\begin{array}{l}\text { Conduct informal observations in classrooms on a } \\
\text { regular basis (informal observations are unscheduled, } \\
\text { last at least } 5 \text { minutes, and may or may not involve } \\
\text { written feedback or a formal conference) }\end{array}$ & 4.6 & 5 & 5 & 4 \\
\hline $\begin{array}{l}\text { Point out specific strengths in teacher's instructional } \\
\text { practices in post-observation feedback (e.g., in } \\
\text { conferences or written evaluations) }\end{array}$ & 4.1 & 5 & 5 & 4 \\
\hline $\begin{array}{l}\text { Point out specific weaknesses in teacher instructional } \\
\text { practices in post-observation feedback (e.g., in } \\
\text { conferences or written evaluations) }\end{array}$ & 4.4 & 5 & 5 & 4 \\
\hline $\begin{array}{l}\text { Make clear who is responsible for coordinating the } \\
\text { curriculum across grade levels (e.g., the principal, vice } \\
\text { principal, or teacher-leader) }\end{array}$ & 3.9 & 5 & 4 & 5 \\
\hline $\begin{array}{l}\text { Draw upon the results of school-wide testing when } \\
\text { making curricular decisions }\end{array}$ & 4.4 & 5 & 5 & 4 \\
\hline $\begin{array}{l}\text { Monitor the classroom curriculum to see that it covers } \\
\text { the school's curricular objectives }\end{array}$ & 4.1 & 5 & 3 & 4 \\
\hline $\begin{array}{l}\text { Assess the overlap between the school's curricular } \\
\text { objectives and the school's achievement tests }\end{array}$ & 4 & 5 & 4 & 4 \\
\hline $\begin{array}{l}\text { Participate actively in the review of curricular } \\
\text { materials }\end{array}$ & 3.9 & 5 & 4 & 4 \\
\hline $\begin{array}{l}\text { Meet individually with teachers to discuss student } \\
\text { progress }\end{array}$ & 4.2 & 4 & 4 & 5 \\
\hline $\begin{array}{l}\text { Discuss academic performance results with the faculty } \\
\text { to identify curricular strengths and weaknesses }\end{array}$ & 4.2 & 5 & 4 & 5 \\
\hline $\begin{array}{l}\text { Use tests and other performance measures to assess } \\
\text { progress toward school goals }\end{array}$ & 4.6 & 5 & 5 & 5 \\
\hline $\begin{array}{l}\text { Inform teachers of the school's performance results in } \\
\text { written form (e.g., in a memo or newsletter) }\end{array}$ & 3.9 & 3 & 2 & 5 \\
\hline Inform students of school's academic progress & 3.6 & 4 & 3 & 5 \\
\hline
\end{tabular}

Note that a score of $1=$ Almost Never, $5=$ Almost Always 
PIMRS results for this domain indicate that Principal $\mathrm{C}$ believes she engages in $80 \%$ of these activities "frequently" or "almost always" and the remaining $20 \%$ of the activities "sometimes" or "seldom." Principal C's supervisor perceived her implementation of these instructional management activities "frequently" $60 \%$ of the time and "almost always" the remaining 40\%. Therefore, Principal C's supervisor generally rated her performance of these instructional leadership activities more highly than she rated herself. In sharp contrast to the results of School A and B, the average teacher rating of the frequency of instructional management behaviors was higher than the principal's own rating $40 \%$ of the time. For $100 \%$ of the behaviors included in this domain, the teacher mode response was equal to or higher than the principal's own response. There were no behaviors for which teachers rated the principal a full point below her self-rating.

As mentioned previously, Principal C's espoused theory of instructional leadership focused a great deal on behaviors related to coordinating the curriculum, supervising and evaluating instruction, and monitoring student progress. The PIMRS data from all three sources indicates that Principal $\mathrm{C}$ does indeed frequently engage in behaviors associated with this instructional leadership domain. Therefore, her theory-inuse (implementation) is very closely aligned with her espoused views.

Developing the school learning climate. The twenty-five behaviors included in this domain of the PIMRS include those associated with the following functions: protects instructional time, provides incentives for teachers, provides incentives for learning, promotes professional development, and maintains high visibility. The espoused theories expressed by Principal $\mathrm{C}$ during qualitative data collection did not focus a great deal on 
any of these behaviors, but emphasized professional development more than the other areas. $15 \%$ of the specific behaviors that Principal $\mathrm{C}$ associated with instructional leadership were classified under this domain. Table 21 , shown on the next two pages, shares results of the PIMRS from each data source related to Principal C's work in developing the school learning climate.

Table 21

School C PIMRS Results: Developing the School Learning Climate

\begin{tabular}{|l|c|c|c|c|}
\hline \multicolumn{1}{|c|}{ PIMRS Instructional Leadership Behavior } & $\begin{array}{c}\text { Teacher } \\
\text { Mean }\end{array}$ & $\begin{array}{c}\text { Teacher } \\
\text { Mode }\end{array}$ & Principal & Supervisor \\
\hline $\begin{array}{l}\text { Limit interruptions of instructional time by public } \\
\text { address announcements }\end{array}$ & 3.5 & 5 & 5 & 4 \\
\hline $\begin{array}{l}\text { Ensure that students are not called to the office during } \\
\text { instructional time }\end{array}$ & 3.2 & 3 & 3 & 4 \\
\hline $\begin{array}{l}\text { Ensure that tardy and truant students suffer specific } \\
\text { consequences for missing instructional time }\end{array}$ & 2.8 & 2 & 1 & 4 \\
\hline $\begin{array}{l}\text { Encourage teachers to use instructional time for } \\
\text { teaching and practicing new skills and concepts }\end{array}$ & 4.5 & 5 & 5 & 5 \\
\hline $\begin{array}{l}\text { Limit the intrusion of extra- and co-curricular } \\
\text { activities on instructional time }\end{array}$ & 3.4 & 4 & 4 & 4 \\
\hline $\begin{array}{l}\text { Take time to talk informally with students and } \\
\text { teachers during recess and breaks }\end{array}$ & 4.6 & 5 & 5 & 4 \\
\hline $\begin{array}{l}\text { Visit classrooms to discuss school issues with teachers } \\
\text { and students }\end{array}$ & 4.2 & 5 & 3 & 5 \\
\hline Attend/participate in extra- and co-curricular activities & 4.4 & 5 & 5 & 3 \\
\hline $\begin{array}{l}\text { Cover classes for teachers until a late or substitute } \\
\text { teacher arrives }\end{array}$ & 2.3 & 1 & 3 & 3 \\
\hline Tutor students or provide direct instruction to classes & 3.9 & 4 & 4 & 5 \\
\hline $\begin{array}{l}\text { Reinforce superior performance by teachers in staff } \\
\text { meetings, newsletters, and/or memos }\end{array}$ & 3.8 & 4 & 4 & 3 \\
\hline $\begin{array}{l}\text { Compliment teachers privately for their efforts or } \\
\text { performance }\end{array}$ & 4 & 5 & 4 & 3 \\
\hline $\begin{array}{l}\text { Acknowledge teachers' exceptional performance by } \\
\text { writing memos for their personnel files }\end{array}$ & 3.5 & 5 & 3 & 3 \\
\hline $\begin{array}{l}\text { Reward special efforts by teachers with opportunities } \\
\text { for professional recognition }\end{array}$ & 3.4 & 3 & 3 & 5 \\
\hline $\begin{array}{l}\text { Create professional growth opportunities for teachers } \\
\text { as a reward for special contributions to the school }\end{array}$ & 3.4 & 3 & 3 & 5 \\
\hline
\end{tabular}




\begin{tabular}{|l|c|c|c|c|}
\hline \multicolumn{1}{|c|}{ PIMRS Instructional Leadership Behavior } & $\begin{array}{c}\text { Teacher } \\
\text { Mean }\end{array}$ & $\begin{array}{c}\text { Teacher } \\
\text { Mode }\end{array}$ & Principal & Supervisor \\
\hline $\begin{array}{l}\text { Ensure that inservice activities attended by staff are } \\
\text { consistent with the school's goals }\end{array}$ & 4.1 & 5 & 4 & 5 \\
\hline $\begin{array}{l}\text { Actively support the use in the classroom of skills } \\
\text { acquired during inservice training }\end{array}$ & 4.1 & 5 & 4 & 5 \\
\hline $\begin{array}{l}\text { Obtain the participation of the whole staff in important } \\
\text { inservice activities }\end{array}$ & 4.4 & 5 & 4 & 5 \\
\hline $\begin{array}{l}\text { Lead or attend teacher inservice activities concerned } \\
\text { with instruction }\end{array}$ & 3.5 & 3 & 5 & 5 \\
\hline $\begin{array}{l}\text { Set aside time at faculty meetings for teachers to share } \\
\text { ideas or information from inservice }\end{array}$ & 4.6 & 5 & 5 & 5 \\
\hline $\begin{array}{l}\text { Recognize students who do superior work with formal } \\
\text { rewards such as an honor roll or mention in the } \\
\text { principal's newsletter }\end{array}$ & 4.3 & 5 & 4 & 5 \\
\hline $\begin{array}{l}\text { Use assemblies to honor students for academic } \\
\text { accomplishments or for behavior or citizenship }\end{array}$ & 3.6 & 3 & 3 & 5 \\
\hline $\begin{array}{l}\text { Recognize superior student achievement or } \\
\text { improvement by seeing in the office students with } \\
\text { their work }\end{array}$ & 4.1 & 5 & 4 & 5 \\
\hline $\begin{array}{l}\text { Contact parents to communicate improved or } \\
\text { exemplary student performance or contributions }\end{array}$ & 3.4 & 4 & 4 & 5 \\
\hline $\begin{array}{l}\text { Support teachers actively in their recognition and/or } \\
\text { reward of student contributions to and } \\
\text { accomplishments in class }\end{array}$ & 4 & 5 & 4 & \\
\hline
\end{tabular}

Note that a score of $1=A l m o s t$ Never, 5=Almost Always

Principal $\mathrm{C}$ rated herself as engaging in instructional leadership tasks related to developing the school learning climate less often than Principals A and B. She claimed to complete these instructional leadership tasks "frequently" or "almost always" $68 \%$ of the time, while her supervisor rated her at that level $88 \%$ of the time. The average teacher in School C perceived that the administrator performed these tasks "frequently" or "almost always" $52 \%$ of the time.

These data indicate that much less disparity exists between the views of the teachers and principal of School C related to Principal C's implementation of instructional leadership work related to developing the school learning climate. Of the 25 tasks listed in this domain, there was only one instance in which teacher mean and mode 
rating were two points less than the principal's self-rating. This area was related to promoting professional development by leading or attending inservice activities related to instruction. In addition, the teacher mean or mode ratings were slightly higher than the principal's self-rating $58 \%$ of the time. These results indicate that perhaps Principal C's theory-in-use leads her to engage in tasks related to developing the school learning climate more often than she realizes based on her espoused theory.

Principal theory-in-use across school settings. There were similarities and differences between each principal's implementation of instructional leadership. Examining the PIMRS data across school settings reveals additional information about principal theory-in-use of instructional leadership at Schools A, B, and C.

Defining the school mission. None of the principals focused heavily on this domain of instructional leadership when expressing their views during qualitative data collection. In contrast, PIMRS data indicated that all of the principals in this study engaged in most tasks related to defining the school mission "frequently" or "almost always." Principals A, B, and C were all rated the lowest in the same two behaviors: ensuring that the school's academic goals are reflected in highly visible displays in the school (e.g. posters or bulletin boards emphasizing academic progress) and referring to the school's goals or mission in forums with students (e.g. in assemblies or discussions). Table 22 on the next page shows the average scores for each principal from each data source for this PIMRS domain. 
Table 22

PIMRS Domain Average Results: Defining the School Mission

\begin{tabular}{|l|c|c|c|c|}
\hline \multicolumn{1}{|c|}{ School Site } & $\begin{array}{c}\text { Teacher } \\
\text { Mean }\end{array}$ & $\begin{array}{c}\text { Teacher } \\
\text { Mode }\end{array}$ & Principal & Supervisor \\
\hline School A & 4.1 & 4.4 & 4.5 & 4.8 \\
\hline School B & 3.8 & 3.9 & 5 & 4.6 \\
\hline School C & 4.2 & 4.7 & 4.6 & 4.5 \\
\hline
\end{tabular}

Note that a score of $1=$ Almost Never, $5=$ Almost Always

Managing the instructional program. All three principals focused a great deal on instructional management behaviors during qualitative data collection and held espoused theories of instructional leadership that emphasized the importance of these behaviors. PIMRS data indicated that Principals A and B believed themselves to be engaging in these instructional activities much more frequently than their teachers perceived that they did, particularly related to supervision and evaluation of instruction. On the contrary, teachers at School $\mathrm{C}$ perceived that their leader was engaging in these activities slightly more frequently than she herself believed that she engaged in them. Table 23 below shows the average scores for each principal from each data source for this PIMRS domain.

Table 23

PIMRS Domain Average Results: Managing the Instructional Program

\begin{tabular}{|l|c|c|c|c|}
\hline \multicolumn{1}{|c|}{ School Site } & $\begin{array}{c}\text { Teacher } \\
\text { Mean }\end{array}$ & $\begin{array}{c}\text { Teacher } \\
\text { Mode }\end{array}$ & Principal & Supervisor \\
\hline School A & 3.7 & 3.9 & 5 & 4.9 \\
\hline School B & 3.8 & 4.0 & 5 & 4.7 \\
\hline School C & 4.2 & 4.7 & 4.1 & 4.4 \\
\hline
\end{tabular}

Note that a score of $1=$ Almost Never, 5=Almost Always 
Developing the school learning climate. Once again, all three of the principals were similar in their espoused theories related to developing the school learning climate. This domain was the least-emphasized area of instructional leadership by each principal, and behaviors in this domain were often not mentioned at all. PIMRS data from all three sources indicated that principals engage in these behaviors less frequently than those associated with instructional management or defining the school mission. This domain also proved to be the area with the greatest disparity between the perceptions of various data sources. Teachers in Schools A and B believed that their leader engaged in these tasks much less frequently than the leaders themselves believed they did. On the contrary, the ratings of teachers at School C were more aligned with the principal's self-ratings, and in many instances teachers at School $\mathrm{C}$ rated the principal more highly than she rated herself. There was very little difference in the supervisor ratings for each of the school leaders in this domain. Table 24 below shows the average scores for each principal from each data source for this PIMRS domain.

Table 24

PIMRS Domain Average Results: Developing the School Learning Climate

\begin{tabular}{|l|c|c|c|c|}
\hline \multicolumn{1}{|c|}{ School Site } & $\begin{array}{c}\text { Teacher } \\
\text { Mean }\end{array}$ & $\begin{array}{c}\text { Teacher } \\
\text { Mode }\end{array}$ & Principal & Supervisor \\
\hline School A & 3.1 & 2.9 & 4.6 & 4.5 \\
\hline School B & 3.3 & 3.3 & 5 & 4.3 \\
\hline School C & 3.8 & 4.2 & 3.8 & 4.4 \\
\hline
\end{tabular}

Note that a score of $1=$ Almost Never, $5=$ Almost Always 


\section{Congruence of Theories of Action}

The PIMRS data, when compiled and compared with qualitative data collected in Phase I, were also used to answer the third research sub-question: What is the relationship between principal espoused theory (beliefs) and theories-in-use (practices) of instructional leadership? The results of this data analysis were included in the previous section related to principal theory-in-use of instructional leadership, but are summarized in this section of the paper. Table 25 below summarizes the data analysis procedures involved in answering this final research question, and how the data contributed to answering it.

Table 25

Compilation of Phase I and Phase II Data

\begin{tabular}{|l|l|}
\hline \multicolumn{1}{|c|}{ Data Analysis } & \multicolumn{1}{c|}{ Results } \\
\hline $\begin{array}{l}\text { Compare/contrast results of principal } \\
\text { interviews (espoused theory) and PIMRS } \\
\text { 360-degree instrument (theories-in-use) }\end{array}$ & $\begin{array}{l}\text { Describe alignment between the two } \\
\text { theories of action for each principal (SQ 3) }\end{array}$ \\
\hline
\end{tabular}

School A. For the three PIMRS domains, Principal A's espoused theory and theory-in-use showed different levels of alignment. The results are summarized in Figure 8 on the next page: 

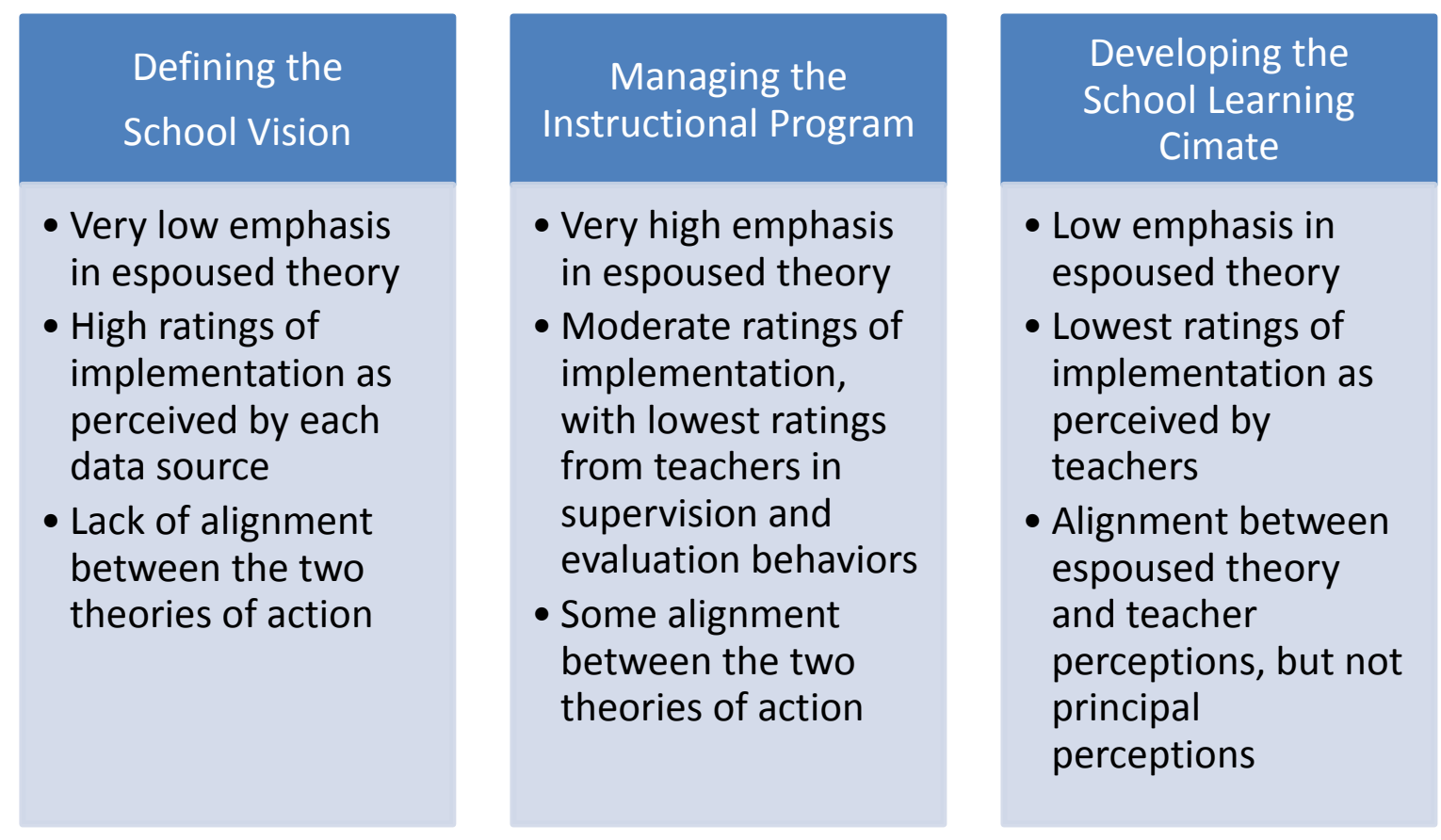

Figure 8

School A: Congruence of Theories of Action

School B. Principal B's espoused theory and theory-in-use also showed different levels of alignment between the three PIMRS domains. The results are summarized in Figure 9 on the following page and are very similar to those of Principal A. 

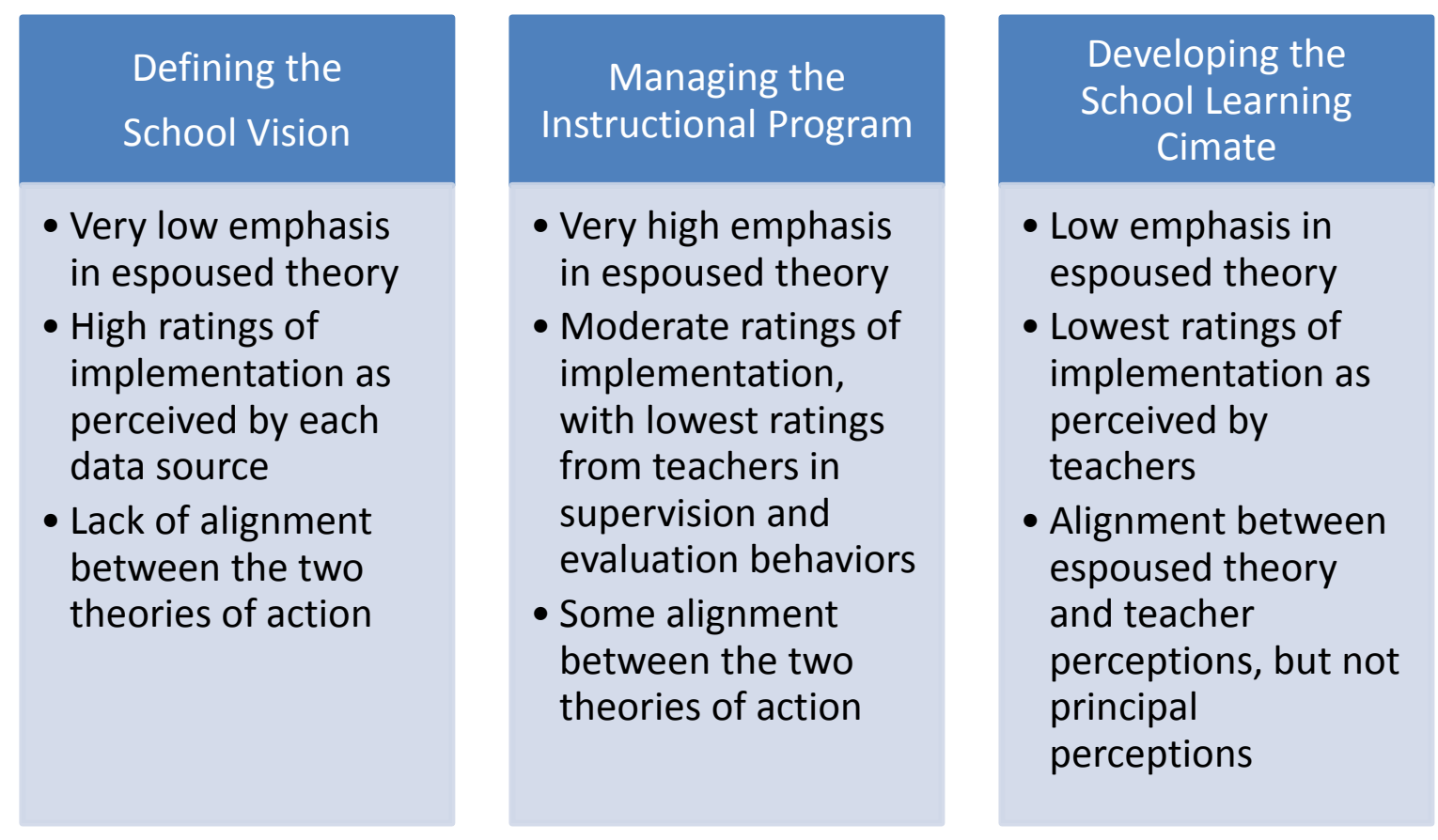

Figure 9

School B: Congruence of Theories of Action

School C. Principal C's espoused theory and theory-in-use also showed different levels of alignment between the three PIMRS domains, with the results summarized in Figure 10, shown on the next page. Principal C's results are distinctive from those of Principals A and B. 

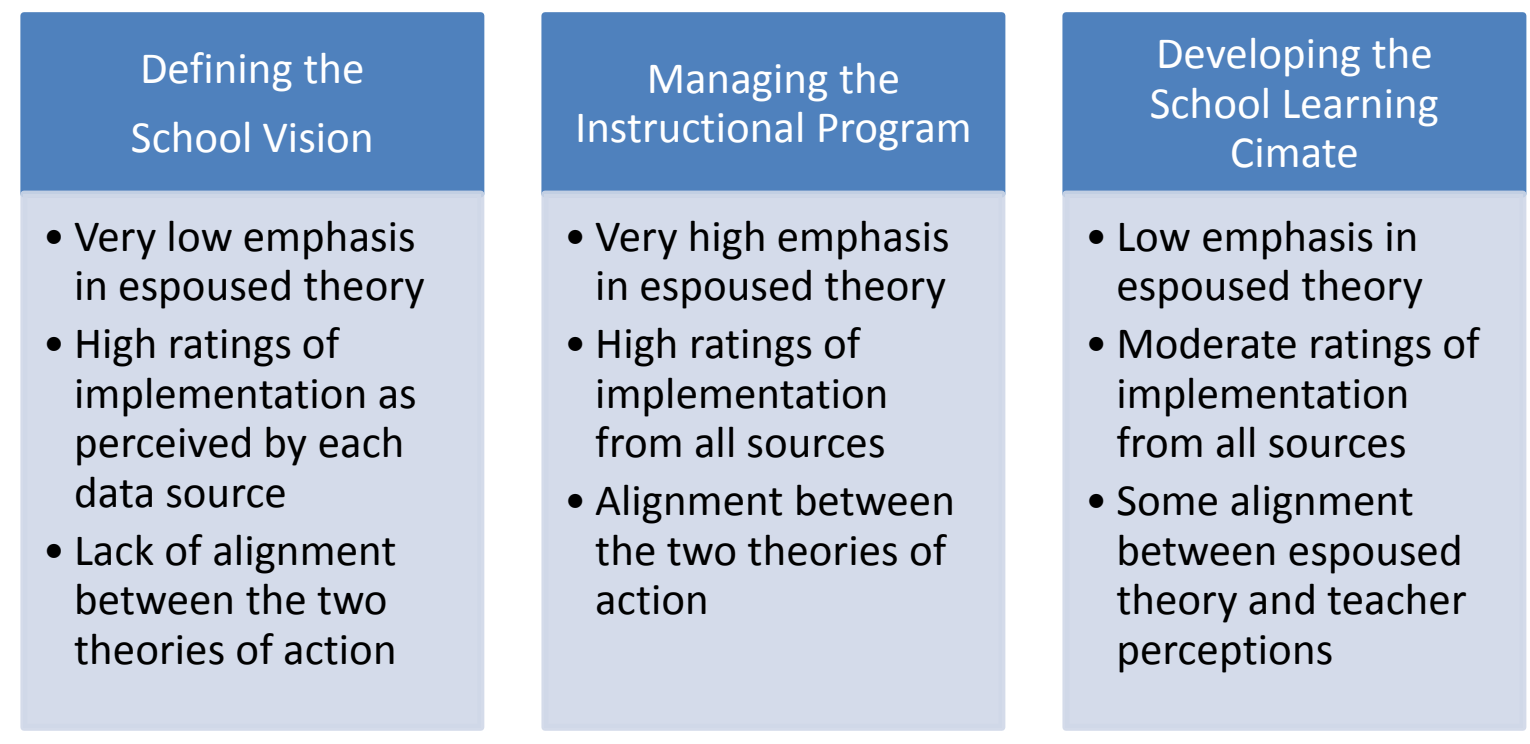

Figure 10

School C: Congruence of Theories of Action

\section{The Principal's Role in Impacting Teacher Quality}

In addition to examining principal perceptions of instructional leadership and comparing those beliefs with their implementation, the researcher was also interested in finding out which instructional leadership activities teachers, principals, and the Director of Elementary Education perceived were most important in increasing teacher professional skill and capacity. To answer this question, data was collected via researcher-written questions that were inserted into the PIMRS document as described in detail in the research methodology. These questions are found in Appendices H, I, and J. This is a particularly salient question due to the lack of time that most principals seem to have available for instructional leadership tasks (Horng, Klasik, \& Loeb, 2010) and the increasing state-level accountability measures for principals based on the results of their instructional leadership work-enhanced teacher quality and thereby, student 
achievement (VDOE, 2012). In this section of the capstone, I will discuss the results of data collection at each school setting and also make comparisons across school sites.

School A. Each data source at School A had markedly different perceptions about which types of principal instructional leadership activities would be most likely to improve teacher skill and capacity. Principal A and the majority of teachers in School A disagreed on which instructional leadership activities are most effective at improving teacher quality $60 \%$ of the time. These perceptions, when compared to the division Director of Elementary Education, were even less aligned. The principal and Director selected different activities as most effective $70 \%$ of the time, while the teachers and Director had different perceptions $80 \%$ of the time.

For four of the ten PIMRS functions, Principal A and most teachers agreed upon the most beneficial activity for enhancing teacher professional capacity. The areas of agreement are as follows:

- Communicates the school goals: Discuss the school's academic goals with teachers at faculty meetings ( $72 \%$ of teachers)

- Coordinates the curriculum: Monitor the classroom curriculum to see that it covers the school's curricular objectives ( $29 \%$ of teachers)

- Promotes professional development: Actively support the use in the classroom of skills acquired during inservice training (43\% of teachers)

- Provides incentives for learning: Support teachers actively in their recognition and/or reward of student contributions to and accomplishments in class (65\% of teachers) 
Principal A and most teachers disagreed about the most beneficial activity associated with 6 of the 10 PIMRS functions. The specific areas of principal and teacher disagreement related to the instructional leadership activities most likely to enhance teacher professional capacity are noted below:

- Frames the school goals: $50 \%$ of teachers chose, "Develop goals that are easily understood and used by teachers in the school" as the principal instructional leadership activity most likely to improve their performance. No other activity in this domain was preferred by more than $21 \%$ of teachers. The principal's selection related to using needs assessments in developing relevant goals, and that perception was shared by only 1 teacher $(7 \%)$.

- Supervises and evaluates instruction: $43 \%$ of teachers preferred that principals, "Ensure that the classroom priorities of teachers are consistent with the goals and direction of the school." $29 \%$ perceived pointing out strengths in post-observation feedback would be most helpful. The principal, however, believed that conducting informal evaluations (walkthroughs) would do the most to positively impact teacher capacity. This belief was shared by only 1 teacher $(7 \%)$.

- Monitors student progress: Only one teacher respondent (7\%) chose the same activity as the principal—using tests to assess progress towards goals. The other teacher responses were divided relatively evenly between three of the other activities included in this function. 
- Protects instructional time: Again, only one teacher's perception aligned with Principal A. They both chose, "Ensure that students are not called to the office during instructional time" as the most beneficial. $43 \%$ of teachers preferred that the principal, "Encourage teachers to use instructional time for teaching and practicing new skills and concepts."

- Maintains high visibility: Teacher opinion was closely tied to two activities in this function. $43 \%$ of teachers selected, "take time to talk informally with students and teachers during recess and breaks," while $36 \%$ chose, "Visit classrooms to discuss school issues with teachers and students." The principal also perceived visiting classrooms as the most beneficial activity.

- Provides incentives for teachers: While Principal A thought that public praise in staff meetings or school publications would be the most motivating and beneficial to teachers, the teachers disagreed. The majority of the teachers $(50 \%)$ chose private compliments on their work as most likely to contribute to their professional growth.

School B. The data sources at School B also held different beliefs about which instructional leadership activities would be most beneficial for enhancing teacher quality. Principal B and the majority of teachers in School B disagreed on which activities were most effective to this end $60 \%$ of the time. The majority of teachers and the Director also disagreed on $60 \%$ of the items, and Principal B and the Director held different perceptions $50 \%$ of the time. 
For four of the ten PIMRS functions, Principal B and most teachers agreed upon the most beneficial activity for enhancing teacher professional capacity. The areas of agreement are as follows:

- Frames the school goals: Use data on student performance when developing the school's academic goals (59\% of teachers)

- Communicates the school goals: Refer to the school's academic goals when making curricular decisions with teachers (47\% of teachers)

- Promotes professional development: Set aside time at faculty meetings for teachers to share ideas or information from inservice activities (69\% of teachers)

- Provides incentives for learning: Support teachers actively in their recognition and/or reward of student contributions to and accomplishments in class (53\% of teachers)

The specific areas of principal and teacher disagreement (6 of 10) related to the most beneficial instructional leadership activities associated with each of the PIMRS functions are noted below:

- Supervises and evaluates instruction: $53 \%$ of the teachers at School B thought that the most effective supervisory activity was for the principal to, "Ensure that the classroom priorities of teachers are consistent with the goals and direction of the school." Principal B, along with $17 \%$ of the teachers, instead perceived that pointing out specific weaknesses in instruction after classroom observations would be more likely to increase teacher capacity. 
- Coordinates the curriculum: Teacher opinion was divided among the activities in this domain. A small majority (29\%) preferred using the results of school-wide testing to make curricular decisions. The principal and $24 \%$ of teachers thought that activities related to aligning school curricular objectives and state achievement tests would be more beneficial to teacher professional capacity.

- Monitors student progress: The vast majority of teachers were divided between 2 of the 5 activities in this section. $41 \%$ thought data-based faculty discussions to assess curricular strengths and weaknesses would be most beneficial, while $36 \%$ preferred individual meetings to discuss student progress. Principal B also thought that individual meetings would be most likely to improve teacher skill and capacity.

- Protects instructional time: $47 \%$ of teachers at School B selected, "Encourage teachers to use instructional time for teaching and practicing new skills and concepts" as the most likely to impact their professional capacity. Principal B thought that providing consequences for students who are tardy/truant would be a more effective activity.

- Maintains high visibility: $47 \%$ of teachers at School B thought that principal visits to the classroom to discuss school issues was the activity most likely to enhance their professional skills. The principal and $30 \%$ of teachers perceived that informal conversations during breaks would be more beneficial. 
- Provides incentives for teachers: Just as was the case in School A, the majority of teachers at School B preferred private compliments on their work (47\%); however, Principal B (along with $12 \%$ of teachers) perceived that public recognition would be more likely to improve teacher professional capacity.

School C. Much like Schools A and B, there was a great deal of disagreement among data sources at School C regarding effective instructional leadership activities. $80 \%$ of the time, the majority of the teachers and the principal held different perceptions regarding which activities would be most beneficial for improving teacher capacity. The views of the majority of teachers and the division Director of Elementary Education were unaligned $60 \%$ of the time. The principal and Director, however, only disagreed $30 \%$ of the time.

For three of the ten PIMRS functions, Principal C and most teachers agreed upon the most beneficial activity for enhancing teacher professional capacity. The areas of agreement are as follows:

- Frames the school goals: Use data on student performance when developing the school's academic goals (41\% of teachers)

- Monitors student progress: Meet individually with teachers to discuss student progress $(59 \%$ of teachers)

- Protects instructional time: Encourage teachers to use instructional time for teaching and practicing new skills and concepts (35\% of teachers) 
The specific areas of principal and teacher disagreement (7 of 10) related to the most beneficial instructional leadership activities associated with each of the PIMRS functions are noted below:

- Communicates the school goals: $44 \%$ of teachers in School C thought discussing school academic goals in faculty meetings would improve their capacity. The principal, along with $31 \%$ of teachers, thought that specifically referring to school goals when making decisions would be more beneficial.

- Supervises and evaluates instruction: Teacher opinion was split almost evenly among the five activities included in this function. A slight majority (30\%) preferred informal classroom walk-throughs for boosting their professional skills, while the principal and $24 \%$ of teachers thought that pointing out specific weaknesses after classroom observations would be the most skill-building activity.

- Coordinates the curriculum: $38 \%$ of teachers believed that principal monitoring of the classroom curriculum to ensure that it covered needed objectives would be most likely to improve teacher skills. The principal and $25 \%$ of teachers instead perceived that using school-wide testing results to make curricular decisions would be more likely to boost teacher professional performance.

- Maintains high visibility: A large majority of teachers $(63 \%)$ thought that having the principal take time to talk to them informally or during breaks would be likely to improve their skills. The principal, however, thought 
that visiting the classroom to discuss school issues would be more beneficial.

- Provides incentives for teachers: As was the case at Schools A and B, teachers in School C (40\%) preferred private compliments on their work as a means of improving their abilities. Conversely, Principal $\mathrm{C}$ believed that public recognition of teacher achievements would be more likely to improve teacher performance.

- Promotes professional development: $63 \%$ of teachers at School C feel that their quality could be enhanced if teachers were provided opportunities at faculty meetings to share ideas and strategies. The principal, along with $25 \%$ of teachers, thought that encouraging teachers to apply strategies learned at professional development courses in the classroom would be more helpful.

- Provides incentives for learning: Teacher opinion was divided nearly evenly among the five activities associated with this function. A slight majority $(31 \%)$ thought that public student recognition would be beneficial, while the principal and $19 \%$ of teachers thought it would be best if the principal encouraged teachers to reward and recognize student contributions themselves.

Impacting teacher quality across school settings. As mentioned previously, the primary finding across the three school settings is related to providing incentives for teachers. At all three school sites, the majority of teachers preferred private compliments on their instruction and thought that would be the most beneficial of the five activities in 
improving their professional skills. In direct contrast to this finding, all three principals believed that public recognition of teacher performance or achievement at faculty meetings or in school newsletters/publications was the best way to achieve teacher professional growth.

\section{Summary of Relevant Findings}

Each of the principals involved in this study were found to have espoused theories of instructional leadership that emphasized the role of knowledge, support, collaboration, progress monitoring, and visibility. These notions are closely tied to the PIMRS framework for effective instructional leadership activities. Additionally, all of the principals believed strongly that their instructional leadership work could impact the teaching and learning that occurs in their schools. However, two specific domains of the PIMRS framework were rarely, if ever, mentioned by each of the principals when discussing her ideas about instructional leadership. Activities or beliefs related to the domains of defining the school vision and developing the school learning climate received very little attention from the school leaders in this study. This lapse could be directly linked to the current initiatives in the school division, and across the state, which focus primarily on the role of assessment and accountability in determining principal and teacher effectiveness. Therefore, instructional leadership activities linked to the domain of managing the school instructional program are more aligned with the principals' daily work and goals, and these activities took center stage when discussing and defining instructional leadership during the interviews.

Examining principal implementation of instructional leadership led to several findings. First, while each principal's espoused theory neglected to focus on the 
instructional leadership domain of defining the school vision, all data sources agreed that the leaders did indeed emphasize these activities when implementing instructional leadership in the schools. The fact that none of the three principals in this study readily referred to the activities in this domain when discussing their ideas of what constitutes instructional leadership, it is likely that the school division in this study does not emphasize tasks related to defining the school vision in principal professional development initiatives. However, even though the principal espoused theory and theoryin-use related to these activities are not aligned, principals were found to be practicing instructional leadership that focuses on defining the school vision, mission, and goals.

Each principal's espoused theory focused heavily on managing the instructional program, mentioning these types of tasks far more frequently than those associated with the other two PIMRS domains. However, teachers in Schools A and B perceived that the principal's implementation of these activities, particularly those related to supervising and evaluating instruction, was less frequent than the principals believed. This indicates incongruence between principal espoused theory and theory-in-use in this domain for Principals A and B. In contrast to Principals A and B, Principal C's espoused theory of instructional leadership also heavily emphasized instructional management tasks, but the PIMRS data indicated that she practiced these activities frequently. Therefore, her theories of action are in alignment as related to instructional management activities. The disconnect between the beliefs and practices of supervision and evaluation of instruction for Principals A and B is likely related to the pressure principals are now facing, with the new evaluation system and school division initiatives focused on accountability, to observe teachers in the classroom and to engage in related supervisory activities as 
frequently as possible. The focus on instructional management was also clearly reflected in the espoused theory of each of the principals, because almost all of the tasks and behaviors they mentioned were related to their work with the school instructional program.

The final PIMRS domain, developing the school learning climate, was practically ignored in the espoused theory of each of the three principals. This domain includes activities such as promoting professional development and providing incentives for teachers are for learning. Despite the neglect of these activities in principal espoused theory, examining principal implementation of these tasks revealed that Principals A and B believed that they practiced these tasks frequently. However, teachers at the two schools perceived that the principals did not implement them with high frequency as part of their instructional leadership work. This indicates that principal espoused theory and theory-in-use of instructional leadership tasks related to developing the school learning climate are aligned, but both indicate a neglect of these activities in the instructional leadership practice. At School C, the principal herself did not believe that she implemented these tasks with as high frequency as the other school leaders. This belief is aligned with her espoused theory, which also de-emphasizes these activities. However, teachers at School C perceived that Principal C implemented instructional leadership tasks related to developing the school learning climate more frequently than she herself believed. This indicates that Principal C's espoused theory and theory-in-use of instructional leadership related to this domain are aligned, but neither heavily emphasize the behaviors in this domain. This domain constitutes $50 \%$ of the behaviors included in the PIMRS instrument, but these behaviors were practiced and discussed far less often 
than those associated with the other two domains. Because none of the principals in this study focused on the role of developing the school learning climate in their beliefs or practices of instructional leadership, school division leaders may conclude that this domain is under-emphasized in the instructional leadership work of many of its principals. These activities are research-based and associated with effective instructional leadership; therefore, the school division may wish to provide principals with professional development related to developing the school learning climate and how these activities can be applied to their work.

When analyzing data related to teacher and principal perceptions about instructional leadership activities most likely to enhance teacher quality, results indicated that data sources typically held very different beliefs. Because principals have demonstrated that they have limited time to engage in instructional leadership, it is imperative that they target their work to the activities that teachers perceive would be the most beneficial to them. Teacher perceptions of instructional leadership are a vacant area of the education research base, so this study explored teacher beliefs in order to provide information to principals about instructional leadership activities that teachers prefer. The beliefs that were found to be in most direct contrast with one another related to providing incentives to teachers. All three of the principals believed that providing public praise or recognition to teachers was the most important way to enhance their performance, while the majority of teachers in each school preferred private compliments on their work. Some of the activities that were selected by principals and teachers as most beneficial were more closely tied. For example, at one school teachers preferred that the principal take time to talk informally with teachers and students about progress, while the principal 
thought that visiting the classroom to discuss school issues would be most appropriate. In practice, there is little difference between these two activities and they may likely accomplish the same goals.

\section{Recommendations in Context}

In this section of the capstone, I will again summarize the problem of practice and purpose of this study, make recommendations for needed action, and discuss relevant factors that might impede implementation of the proposed solutions.

Summary of problem of practice and purpose of study. Given new state policies regulating principal evaluation, Virginia school leaders will soon be held accountable by the state and school division for their role in student learning (VDOE, 2012). It remains to be seen what the large-scale impact of this policy change will be. Regardless, for Washington County school leaders, the changes in policy raised several important questions about their instructional leadership practices as well as their perceptions about their instructional leadership responsibilities and their impact on teacher quality and student achievement. For example, how do principals understand their instructional leadership responsibilities? How do they allocate their time and effort, and do they engage in leadership practices that impact teacher quality, and thereby, student achievement? In light of these relevant questions, the purpose of this project was to explore the nature of principal instructional leadership in Washington County in order to: 1) ascertain principal readiness for the implementation of the new evaluation system, and 2) to use that assessment of readiness to assist individual principals and district leaders to increase readiness. Gaining a better sense of leaders' beliefs about instructional leadership, to what degree this responsibility is emphasized in their work, and how their 
instructional leadership is practiced and perceived by a variety of stakeholders provides insight that can be used to support school leaders' professional learning.

In addition to simply learning about the instructional leadership beliefs and practices of elementary school leaders in Washington County, this project focused on understanding the consistency between leadership beliefs and leadership practice. Specifically, the juxtaposition of limited time allocated towards instructional leadership despite its acknowledged importance in the field suggested potential inconsistencies between principal espoused theory and theories-in-use related to instructional leadership (Argyris \& Schön, 1974). Argyris asserted that congruency between the two theories leads to the most effective designs of action (1980). This suggests that purposeful alignment of principal beliefs (espoused theory) and implementation (theories-in-use) of instructional leadership could potentially be a lever for improving practice.

Possible solutions and recommendations. This study was primarily descriptive and exploratory in design and set out to discover the nature of principal instructional leadership in order to provide school leaders with information that could be beneficial to them when adapting to the state-wide principal evaluation policy changes. Therefore, the very "solution" to the problem of practice lies in the communication of relevant findings to the school leaders in this study in a format that can be easily understood, applied to their work, and potentially lead to a change in behavior.

Byrne (1991) called for increasing presence of feedback for leaders in the business world, claiming that 'CEO disease' abounded in organizations where leaders did not seek out or were not provided with feedback that could enhance their performance. This study intentionally used a 360 degree survey instrument to allow for comparison and 
contrast of the perceptions of various data sources, with results used by the school leaders as an impetus for professional reflection and growth. Leader self-ratings alone have been shown to be poor predictors of performance (Church, 2000; Harris \& Schaubroech, 1988; Sala \& Dwight, 2002). Some researchers propose that this disconnect between selfratings and job performance is due to leniency bias in self-ratings (Podsakoff \& Organ, 1986; Van Velsor et al., 1993). This type of bias seemed to exist in this study as well, as one of the three school leaders gave herself the highest possible rating in every category, and principal self-ratings were almost always higher than the ratings of other source groups.

Organizational leaders can empower themselves and their subordinates in the process of ongoing learning through use of multi-source feedback (London, 2002). Avolio (2005, p. 94) states: "To be an effective leader means to reflect, deeply reflect, on events that surround oneself that have reference to how you see our own behavior and actions influencing others." Sala (2003) claims that, "360-degree feedback systems enhance self-knowledge and can consequently improve managerial behaviors." The comparison of multi-rater feedback to self-perceptions using these types of instruments can enhance self-awareness and lead to behavioral change (Church, 2000). Selfawareness has been linked by several researchers to heightened individual performance (Atwater \& Yammarino, 1992; Church \& Waclawski, 1999; Van Velsor et al., 1993). The idealistic goal of 360-degree feedback is that leaders will "adjust their behavior as they watch the impact [that their behaviour] is having on followers" (Avolio, 2005, p. 95). Brutus et al. (1999) found that as a result of multi-source feedback, leaders selected 
relevant professional development goals, and that subordinate ratings were highly influential during the goal-setting process.

The notion of self-awareness leading to a change in behavior echoes the ideas that serve as the theoretical framework of this study. When defining his two theories of action, Argyris (1987) asserted that whether conscious or subconscious, actors design and implement their own courses of action and are responsible for the intended and unintended consequences of those designs. Furthermore, self-awareness, like that resulting from a 360 degree intervention, plays a critical role in behavior change because actors can often be unaware of their implemented designs and how they may be different from their espoused ideals (Argyris \& Schön 1974).

For professional learning to occur, actors must reconcile what they "say they do and their explanations for their actions" with "what they actually do and the real reasons for their actions" (Robinson and Lai, 2006, p. 99). For actors, in this case, school leaders, to change their behavior, they must first realize what incongruity exists between their espoused theory and theory-in-use (Argyris, 1980). Recognition of this disparity is critical, Argyris (1980) asserted, because actions are most effective when espoused theory and theory-in-use are in alignment. Furthermore, discrepancies between the two theories can have a negative effect in educational organizations (Schön, 1983).

Therefore, critically examining and sharing the data generated from the PIMRS instrument and other data collected during this study could enhance self-awareness and lead to behavior change for the participating school leaders. This is an important and timely topic because reflection on principal instructional leadership activities and whether and how these tasks contribute to teacher professional growth could assist principals in 
adapting to the new evaluation system which heavily evaluates them on the results of their instructional leadership-enhanced teacher quality and thereby, student achievement. The specific instructional leadership practices of the three principals, based on the individual school site data and analysis, are described and outlined in further detail in the next section of this paper: Action Communications.

Barriers to implementation. While the ideal goal of 360 degree interventions is to provide useful information to leaders to enhance professional practice, this goal may not be realized. The primary barrier that will impede change in this case is time and/or time management. Several studies cited earlier in this paper (Horng, Klasik, \& Loeb, 2010; Goldring et al., 2007) emphasize the limited amount of time that principals have available to devote to instructional leadership tasks. Quite frankly, finding time to engage in new instructional leadership activities, to engage in them more frequently, or even to analyze, reflect upon, or apply the information provided to them as a result of this study may be a distinct challenge for the participating school leaders. Without meaningful reflection and purposeful action on the part of school leaders, behavior changes that could assist them or their organizations will likely not occur.

Despite the challenge of finding time to reflect, another potential barrier to change relates to the perceived meaningfulness of the data and results. If the school leaders do not value the feedback of their subordinates and superior, they may disagree with the results of the instrument and be hesitant to make any changes to their current leadership practices. Conversely, the principal participants may be very receptive to the feedback from these data sources; in that case, they may be willing to use the information they 
receive to enhance their current leadership practices, akin to the findings of Brutus and colleagues (1999).

A third potential barrier to lasting change is consistency of implementation. Supposing that school leaders do find the time to reflect on the information provided to them and make relevant changes to their leadership practice, the changes that they make may not be lasting. Education is a field that changes constantly. New regulations, rules, and trends frequently enter the scene, and as new initiatives enter, older ones often fade to the background. One such change is the Virginia state principal evaluation system that serves as a critical focus of this study (VDOE, 2012). The waxing and waning of educational initiatives may make it difficult for leaders who do attempt to make changes to their instructional leadership practice to sustain these changes over time due to the shifting landscape of educational policy.

\section{Implications of Findings for Further Research}

This study was limited to three small schools in a rural school division in Virginia, and the results cannot be generalized to other settings. However, the findings did raise relevant issues for further research. Further investigation is needed into the link between principal leadership practice and teacher quality-specifically, how principals impact teacher quality through their instructional leadership behaviors. This was a major vacancy in the current research base. Similarly, current scholarly literature remains silent on issues related to principal perceptions of instructional leadership practices and which ones may be most beneficial to teachers. This study examined the perceptions of teachers in the identified sample, but further examination of the activities that principals could engage in that might help teachers-or certain groups of teachers-improve their 
professional capacity could help principals target their instructional leadership appropriately, especially since the amount of time available is limited.

Another potential area of interest for future researchers is principal espoused theory of instructional leadership. In this study, the participating school leaders worked for the same school division, and all three held very similar beliefs about instructional leadership, what constitutes it, and the impact it has on teaching and learning in the schools. Studying espoused theory of leaders in other areas across the nation and even internationally would provide insight into whether these beliefs may stem from local leadership development and/or how they may vary from one location to another. This would help researchers understand the underlying theory behind principal practice of instructional leadership, because as Argyris claims, espoused theory plays a critical role in implementation (1987).

Another avenue for further research would be a correlational study that seeks to determine whether frequency of principal implementation of research-based instructional leadership activities is positively correlated with variables such as teacher summative evaluation scores, student achievement, or teacher turnover rates. A study such as this would help to strengthen the link between leadership, teacher quality, and student learning. 


\section{Action Communications}

In this section of the paper, I explain how the results of this project will be communicated to the participating school principals and school division leaders. Through the action communications described below, the results of the 360 degree intervention and qualitative data collection will be distributed to principals. Due to the nature of this project, the action communications are very closely tied to the recommendations.

\section{Principal Review Briefing}

The first step in sharing results of this study is through a principal review briefing. During this meeting, held individually with each principal, I will present the findings from qualitative and quantitative data collection about the principal's beliefs and implementation of instructional leadership as perceived by each data source. All of this information will be complied into an Instructional Leadership Action Profile, a document that will be shared with the principal during the meeting. The Action Profile will outline principal beliefs about instructional leadership (shared during the interview with the researcher), the results of the PIMRS 360 degree intervention, and the correlation between principal beliefs and implementations of instructional leadership as suggested by these data. Fulfilling the purpose of this project, this document is intended to assist principals in reflecting upon their instructional leadership beliefs and practices in order to increase readiness for the new principal evaluation system. The Instructional Leadership Action Profiles for each of the three principals are shared on the following pages. 


\section{Instructional Leadership Action Profile: School A}

This document summarizes data collected from your school as part of your participation in a doctoral research project during the 2013-2014 school year. Thank you for your participation.Please contact lah3we@virginia.edu with any questions/concerns.

\section{- Beliefs about Instructional Leadership}

During your interview, you emphasized the following items as critical components of your instructional leadership practice:

- Knowledge

- Support

- Collaboration

- Progress Monitoring

- Visibility

- Impact

The chart to the right shows the frequency of research-based instructional leadership behaviors that

\begin{tabular}{|l|c|}
\hline \multicolumn{1}{|c|}{$\begin{array}{c}\text { PIMRS Domain } \\
\text { (Hallinger \& Murphy, 1985) }\end{array}$} & $\begin{array}{c}\text { Frequency } \\
\text { Mentioned }\end{array}$ \\
\hline Frames the School's Goals & 1 \\
\hline Communicates the School's Goals & 1 \\
\hline Coordinates the Curriculum & 3 \\
\hline Supervises \& Evaluates Instruction & 5 \\
\hline Monitors Student Progress & 7 \\
\hline Protects Instructional Time & 0 \\
\hline Provides Incentives for Teachers & 1 \\
\hline Provides Incentives for Learning & 1 \\
\hline Promotes Professional Development & 3 \\
\hline Maintains High Visibility & 1 \\
\hline
\end{tabular}
were discussed at that time.

\section{- Implementation of Instructional Leadership}

The tables below show the results of the PIMRS 360 Degree survey, administered to you, your teachers, and the division Director of Elementary Education. $67 \%$ of your teachers participated in the survey. Note that a score of $1=$ Almost Never and 5=Almost Always.

\begin{tabular}{|l|c|c|c|c|}
\hline \multicolumn{1}{|c|}{ Frames the School Goals } & $\begin{array}{c}\text { Teacher } \\
\text { Mean }\end{array}$ & $\begin{array}{c}\text { Teacher } \\
\text { Mode }\end{array}$ & Self & Dir. \\
\hline Develop a focused set of annual school-wide goals & 4.5 & 5 & 5 & 5 \\
\hline $\begin{array}{l}\text { Frame the school's goals in terms of staff responsibilities for meeting } \\
\text { them }\end{array}$ & 4.6 & 5 & 4 & 5 \\
\hline $\begin{array}{l}\text { Use needs assessment or other formal and informal methods to secure } \\
\text { staff input on goal development }\end{array}$ & 4.4 & 5 & 4 & 5 \\
\hline $\begin{array}{l}\text { Use data on student performance when developing the school's } \\
\text { academic goals }\end{array}$ & 4.7 & 5 & 5 & 5 \\
\hline $\begin{array}{l}\text { Develop goals that are easily understood and used by teachers in the } \\
\text { school }\end{array}$ & 4.1 & 5 & 5 & 5 \\
\hline
\end{tabular}




\begin{tabular}{|l|c|c|c|c|}
\hline \multicolumn{1}{|c|}{ Communicates the School Goals } & $\begin{array}{c}\text { Teacher } \\
\text { Mean }\end{array}$ & $\begin{array}{c}\text { Teacher } \\
\text { Mode }\end{array}$ & Self & Dir. \\
\hline $\begin{array}{l}\text { Communicate the school's mission effectively to members of the } \\
\text { school community }\end{array}$ & 3.8 & 5 & 4 & 5 \\
\hline Discuss the school's academic goals with teachers at faculty meetings & 4.4 & 5 & 5 & 5 \\
\hline $\begin{array}{l}\text { Refer to the school's academic goals when making curricular } \\
\text { decisions with teachers }\end{array}$ & 4.2 & 4 & 5 & 5 \\
\hline $\begin{array}{l}\text { Ensure that the school's academic goals are reflected in highly visible } \\
\text { displays in the school (e.g. posters or bulletin boards emphasizing } \\
\text { academic progress) }\end{array}$ & 3.0 & 3 & 4 & 4 \\
\hline $\begin{array}{l}\text { Refer to the school's goals or mission in forums with students (e.g. in } \\
\text { assemblies or discussions) }\end{array}$ & 2.5 & 2 & 4 & 4 \\
\hline
\end{tabular}

*Results from this function (Supervises and Evaluates Instruction) showed some of the greatest differences between your self-rating and teacher ratings for each activity:

\begin{tabular}{|c|c|c|c|c|}
\hline Supervises \& Evaluates Instruction & $\begin{array}{c}\text { Teacher } \\
\text { Mean }\end{array}$ & $\begin{array}{c}\text { Teacher } \\
\text { Mode }\end{array}$ & Self & Dir. \\
\hline $\begin{array}{l}\text { Ensure that the classroom priorities of teachers are consistent with the } \\
\text { goals and direction of the school }\end{array}$ & 4 & 4 & 5 & 5 \\
\hline Review student work products when evaluating classroom instruction & 2.9 & 3 & 5 & 5 \\
\hline $\begin{array}{l}\text { Conduct informal observations in classrooms on a regular basis } \\
\text { (informal observations are unscheduled, last at least } 5 \text { minutes, and } \\
\text { may or may not involve written feedback or a formal conference) }\end{array}$ & 3.3 & 3 & 5 & 5 \\
\hline $\begin{array}{l}\text { Point out specific strengths in teacher's instructional practices in post- } \\
\text { observation feedback (e.g., in conferences or written evaluations) }\end{array}$ & 3 & 3 & 5 & 5 \\
\hline $\begin{array}{l}\text { Point out specific weaknesses in teacher instructional practices in } \\
\text { post-observation feedback (e.g., in conferences or written evaluations) }\end{array}$ & 3.6 & 3 & 5 & 5 \\
\hline
\end{tabular}

\begin{tabular}{|c|c|c|c|c|}
\hline Coordinates the Curriculum & $\begin{array}{l}\text { Teacher } \\
\text { Mean }\end{array}$ & $\begin{array}{l}\text { Teacher } \\
\text { Mode }\end{array}$ & Self & Dir. \\
\hline $\begin{array}{l}\text { Make clear who is responsible for coordinating the curriculum across } \\
\text { grade levels (e.g., the principal, vice principal, or teacher-leader) }\end{array}$ & 3.7 & 5 & 5 & 5 \\
\hline $\begin{array}{l}\text { Draw upon the results of school-wide testing when making curricular } \\
\text { decisions }\end{array}$ & 4.6 & 5 & 5 & 5 \\
\hline $\begin{array}{l}\text { Monitor the classroom curriculum to see that it covers the school's } \\
\text { curricular objectives }\end{array}$ & 4.2 & 5 & 5 & 5 \\
\hline $\begin{array}{l}\text { Assess the overlap between the school's curricular objectives and the } \\
\text { school's achievement tests }\end{array}$ & 4.3 & 5 & 5 & 5 \\
\hline Participate actively in the review of curricular materials & 3.8 & 3 & 5 & 4 \\
\hline
\end{tabular}




\begin{tabular}{|l|c|c|c|c|}
\hline \multicolumn{1}{|c|}{ Monitors Student Progress } & $\begin{array}{c}\text { Teacher } \\
\text { Mean }\end{array}$ & $\begin{array}{c}\text { Teacher } \\
\text { Mode }\end{array}$ & Self & Dir. \\
\hline Meet individually with teachers to discuss student progress & 3.7 & 4 & 5 & 5 \\
\hline $\begin{array}{l}\text { Discuss academic performance results with the faculty to identify } \\
\text { curricular strengths and weaknesses }\end{array}$ & 3.8 & 4 & 5 & 5 \\
\hline $\begin{array}{l}\text { Use tests and other performance measures to assess progress toward } \\
\text { school goals }\end{array}$ & 4.4 & 5 & 5 & 5 \\
\hline $\begin{array}{l}\text { Inform teachers of the school's performance results in written form } \\
\text { (e.g., in a memo or newsletter) }\end{array}$ & 3.4 & 4 & 5 & 4 \\
\hline Inform students of school's academic progress & 2.6 & 2 & 5 & 5 \\
\hline
\end{tabular}

\begin{tabular}{|l|c|c|c|c|}
\hline \multicolumn{1}{|c|}{ Protects Instructional Time } & $\begin{array}{c}\text { Teacher } \\
\text { Mean }\end{array}$ & $\begin{array}{c}\text { Teacher } \\
\text { Mode }\end{array}$ & Self & Dir. \\
\hline $\begin{array}{l}\text { Limit interruptions of instructional time by public address } \\
\text { announcements }\end{array}$ & 4.6 & 5 & 5 & 5 \\
\hline $\begin{array}{l}\text { Ensure that students are not called to the office during instructional } \\
\text { time }\end{array}$ & 4.2 & 5 & 5 & 4 \\
\hline $\begin{array}{l}\text { Ensure that tardy and truant students suffer specific consequences for } \\
\text { missing instructional time }\end{array}$ & 2.1 & 2 & 4 & 5 \\
\hline $\begin{array}{l}\text { Encourage teachers to use instructional time for teaching and } \\
\text { practicing new skills and concepts }\end{array}$ & 4.9 & 5 & 5 & 5 \\
\hline $\begin{array}{l}\text { Limit the intrusion of extra- and co-curricular activities on } \\
\text { instructional time }\end{array}$ & 4.5 & 5 & 5 & 4 \\
\hline
\end{tabular}

*Results from this function (Maintains High Visibility) showed some of the greatest differences between your self-rating and teacher ratings for each activity:

\begin{tabular}{|l|c|c|c|c|}
\hline \multicolumn{1}{|c|}{ Maintains High Visibility } & $\begin{array}{c}\text { Teacher } \\
\text { Mean }\end{array}$ & $\begin{array}{c}\text { Teacher } \\
\text { Mode }\end{array}$ & Self & Dir. \\
\hline $\begin{array}{l}\text { Take time to talk informally with students and teachers during recess } \\
\text { and breaks }\end{array}$ & 2.4 & 2 & 5 & 4 \\
\hline Visit classrooms to discuss school issues with teachers and students & 2.9 & 3 & 4 & 5 \\
\hline Attend/participate in extra- and co-curricular activities & 3.3 & 2 & 4 & 5 \\
\hline Cover classes for teachers until a late or substitute teacher arrives & 1.9 & 1 & 3 & 3 \\
\hline Tutor students or provide direct instruction to classes & 1.4 & 1 & 3 & 3 \\
\hline
\end{tabular}


*Results from this function (Provides Incentives for Teachers) showed some of the greatest differences between your self-rating and teacher ratings for each activity:

\begin{tabular}{|l|c|c|c|c|}
\hline \multicolumn{1}{|c|}{ Provides Incentives for Teachers } & $\begin{array}{c}\text { Teacher } \\
\text { Mean }\end{array}$ & $\begin{array}{c}\text { Teacher } \\
\text { Mode }\end{array}$ & Self & Dir. \\
\hline $\begin{array}{l}\text { Reinforce superior performance by teachers in staff meetings, } \\
\text { newsletters, and/or memos }\end{array}$ & 2.4 & 3 & 5 & 5 \\
\hline Compliment teachers privately for their efforts or performance & 2.4 & 2 & 5 & 5 \\
\hline $\begin{array}{l}\text { Acknowledge teachers' exceptional performance by writing memos } \\
\text { for their personnel files }\end{array}$ & 2 & 1 & 3 & 3 \\
\hline $\begin{array}{l}\text { Reward special efforts by teachers with opportunities for professional } \\
\text { recognition }\end{array}$ & 2.3 & 3 & 5 & 4 \\
\hline $\begin{array}{l}\text { Create professional growth opportunities for teachers as a reward for } \\
\text { special contributions to the school }\end{array}$ & 2.5 & 1 & 4 & 3 \\
\hline
\end{tabular}

\begin{tabular}{|l|c|c|c|c|}
\hline \multicolumn{1}{|c|}{ Promotes Professional Development } & $\begin{array}{c}\text { Teacher } \\
\text { Mean }\end{array}$ & $\begin{array}{c}\text { Teacher } \\
\text { Mode }\end{array}$ & Self & Dir. \\
\hline $\begin{array}{l}\text { Ensure that inservice activities attended by staff are consistent with } \\
\text { the school's goals }\end{array}$ & 4 & 4 & 5 & 5 \\
\hline $\begin{array}{l}\text { Actively support the use in the classroom of skills acquired during } \\
\text { inservice training }\end{array}$ & 4 & 4 & 5 & 5 \\
\hline $\begin{array}{l}\text { Obtain the participation of the whole staff in important inservice } \\
\text { activities }\end{array}$ & 3.9 & 5 & 5 & 5 \\
\hline $\begin{array}{l}\text { Lead or attend teacher inservice activities concerned with instruction } \\
\text { Set aside time at faculty meetings for teachers to share ideas or } \\
\text { information from inservice }\end{array}$ & 4.3 & 5 & 5 & 4 \\
\hline
\end{tabular}

*Results from this function (Provides Incentives for Learning) showed some of the greatest differences between your self-rating and teacher ratings for each activity:

\begin{tabular}{|c|c|c|c|c|}
\hline Provides Incentives for Learning & $\begin{array}{l}\text { Teacher } \\
\text { Mean }\end{array}$ & $\begin{array}{l}\text { Teacher } \\
\text { Mode }\end{array}$ & Self & Dir. \\
\hline $\begin{array}{l}\text { Recognize students who do superior work with formal rewards such } \\
\text { as an honor roll or mention in the principal's newsletter }\end{array}$ & 3.8 & 3 & 5 & 5 \\
\hline $\begin{array}{l}\text { Use assemblies to honor students for academic accomplishments or } \\
\text { for behavior or citizenship }\end{array}$ & 2.3 & 1 & 5 & 5 \\
\hline $\begin{array}{l}\text { Recognize superior student achievement or improvement by seeing in } \\
\text { the office students with their work }\end{array}$ & 2 & 1 & 4 & 5 \\
\hline $\begin{array}{l}\text { Contact parents to communicate improved or exemplary student } \\
\text { performance or contributions }\end{array}$ & 1.8 & 1 & 5 & 5 \\
\hline $\begin{array}{l}\text { Support teachers actively in their recognition and/or reward of student } \\
\text { contributions to and accomplishments in class }\end{array}$ & 3.1 & 3 & 5 & 5 \\
\hline
\end{tabular}




\section{- Improving Teacher Capacity via Instructional Leadership}

The table below shows the specific activities for each research-based instructional leadership category that you and participating teachers felt would be most beneficial for increasing teacher professional capacity. These data were collected from you and from participating teachers as an addendum to the PIMRS Instrument.

\begin{tabular}{|c|c|c|}
\hline \multirow[t]{2}{*}{ PIMRS Function } & \multicolumn{2}{|c|}{ Most beneficial activity as perceived by.... } \\
\hline & Teachers & Principal \\
\hline \multirow[t]{5}{*}{$\begin{array}{l}\text { Frames the } \\
\text { School's Goals }\end{array}$} & $\begin{array}{l}\text { Develop goals that are easily understood and } \\
\text { used by teachers in the school }(50 \%)\end{array}$ & \multirow{5}{*}{$\begin{array}{l}\text { Use needs assessment or } \\
\text { other formal and informal } \\
\text { methods to secure staff } \\
\text { input on goal development }\end{array}$} \\
\hline & $\begin{array}{l}\text { Develop a focused set of annual school-wide } \\
\text { goals }(0 \%)\end{array}$ & \\
\hline & $\begin{array}{l}\text { Frame the school's goals in terms of staff } \\
\text { responsibilities for meeting them }(21.43 \%)\end{array}$ & \\
\hline & $\begin{array}{l}\text { Use needs assessment or other formal and } \\
\text { informal methods to secure staff input on goal } \\
\text { development }(7.14 \%)\end{array}$ & \\
\hline & $\begin{array}{l}\text { Use data on student performance when } \\
\text { developing the school's academic goals } \\
(21.43 \%)\end{array}$ & \\
\hline \multirow[t]{5}{*}{$\begin{array}{l}\text { Communicates the } \\
\text { School's Goals }\end{array}$} & $\begin{array}{l}\text { Discuss the school's academic goals with } \\
\text { teachers at faculty meetings ( } 71.43 \%)\end{array}$ & \multirow{5}{*}{$\begin{array}{l}\text { Discuss the school's } \\
\text { academic goals with } \\
\text { teachers at faculty } \\
\text { meetings }\end{array}$} \\
\hline & $\begin{array}{l}\text { Communicate the school's mission effectively } \\
\text { to members of the school community }(7.14 \%)\end{array}$ & \\
\hline & $\begin{array}{l}\text { Refer to the school's academic goals when } \\
\text { making curricular decisions with teachers } \\
(7.14 \%)\end{array}$ & \\
\hline & $\begin{array}{l}\text { Ensure that the school's academic goals are } \\
\text { reflected in highly visible displays in the } \\
\text { school }(7.14 \%)\end{array}$ & \\
\hline & $\begin{array}{l}\text { Refer to the school's goals or mission in } \\
\text { forums with students }(7.14 \%)\end{array}$ & \\
\hline \multirow[t]{5}{*}{$\begin{array}{l}\text { Coordinates the } \\
\text { Curriculum }\end{array}$} & $\begin{array}{l}\text { Monitor the classroom curriculum to see that } \\
\text { it covers the school's curricular objectives } \\
(28.57 \%)\end{array}$ & \multirow{5}{*}{$\begin{array}{l}\text { Monitor the classroom } \\
\text { curriculum to see } \\
\text { that it covers the school's } \\
\text { curricular objectives }\end{array}$} \\
\hline & $\begin{array}{l}\text { Make clear who is responsible for } \\
\text { coordinating the curriculum across grade } \\
\text { levels }(21.43 \%)\end{array}$ & \\
\hline & $\begin{array}{l}\text { Draw upon the results of school-wide testing } \\
\text { when making curricular decisions }(14.29 \%)\end{array}$ & \\
\hline & $\begin{array}{l}\text { Assess the overlap between the school's } \\
\text { curricular objectives and the school's } \\
\text { achievement tests }(21.43 \%)\end{array}$ & \\
\hline & $\begin{array}{l}\text { Participate actively in the review of curricular } \\
\text { materials } 14.29 \% \text { ) }\end{array}$ & \\
\hline
\end{tabular}




\begin{tabular}{|c|c|c|}
\hline \multirow[t]{2}{*}{ PIMRS Function } & \multicolumn{2}{|c|}{ Most beneficial activity as perceived by.... } \\
\hline & Teachers & Principal \\
\hline \multirow[t]{5}{*}{$\begin{array}{c}\text { Supervises \& } \\
\text { Evaluates Instruction }\end{array}$} & $\begin{array}{l}\text { Ensure that the classroom priorities of } \\
\text { teachers are consistent with the goals and } \\
\text { direction of the school }(42.86 \%)\end{array}$ & \multirow[t]{5}{*}{$\begin{array}{l}\text { Conduct informal } \\
\text { observations in classrooms } \\
\text { on a regular basis }\end{array}$} \\
\hline & $\begin{array}{l}\text { Review student work products when } \\
\text { evaluating classroom instruction }(7.14 \%)\end{array}$ & \\
\hline & $\begin{array}{l}\text { Conduct informal observations in classrooms } \\
\text { on a regular basis }(7.14 \%)\end{array}$ & \\
\hline & $\begin{array}{l}\text { Point out specific strengths in teacher's } \\
\text { instructional practices in post-observation } \\
\text { feedback }(28.57 \%)\end{array}$ & \\
\hline & $\begin{array}{l}\text { Point out specific weaknesses in teacher } \\
\text { instructional practices in post-observation } \\
\text { feedback }(14.29 \%)\end{array}$ & \\
\hline \multirow[t]{5}{*}{$\begin{array}{l}\text { Monitors Student } \\
\text { Progress }\end{array}$} & $\begin{array}{l}\text { Discuss academic performance results with } \\
\text { the faculty to identify curricular strengths and } \\
\text { weaknesses }(35.71 \%)\end{array}$ & \multirow{5}{*}{$\begin{array}{l}\text { Use tests and other } \\
\text { performance measure to } \\
\text { assess progress toward } \\
\text { school goals }\end{array}$} \\
\hline & $\begin{array}{l}\text { Meet individually with teachers to discuss } \\
\text { student progress }(28.57 \%)\end{array}$ & \\
\hline & $\begin{array}{l}\text { Use tests and other performance measure to } \\
\text { assess progress toward school goals }(7.14 \%)\end{array}$ & \\
\hline & $\begin{array}{l}\text { Inform teachers of the school's performance } \\
\text { results in written form }(28.57 \%)\end{array}$ & \\
\hline & $\begin{array}{l}\text { Inform students of school's academic progress } \\
(0 \%)\end{array}$ & \\
\hline \multirow[t]{5}{*}{$\begin{array}{c}\text { Protects Instructional } \\
\text { Time }\end{array}$} & $\begin{array}{l}\text { Encourage teachers to use instructional time } \\
\text { for teaching and practicing new skills and } \\
\text { concepts }(42.86 \%)\end{array}$ & \multirow[t]{5}{*}{$\begin{array}{l}\text { Ensure that students are not } \\
\text { called to the office during } \\
\text { instructional time }\end{array}$} \\
\hline & $\begin{array}{l}\text { Limit interruptions of instructional time by } \\
\text { public address announcements }(14.29 \%)\end{array}$ & \\
\hline & $\begin{array}{l}\text { Ensure that students are not called to the } \\
\text { office during instructional time }(7.14 \%)\end{array}$ & \\
\hline & $\begin{array}{l}\text { Ensure that tardy and truant students suffer } \\
\text { specific consequences for missing } \\
\text { instructional time }(14.29 \%)\end{array}$ & \\
\hline & $\begin{array}{l}\text { Limit the intrusion of extra- and co-curricular } \\
\text { activities on instructional time }(21.43 \%)\end{array}$ & \\
\hline \multirow{5}{*}{$\begin{array}{l}\text { Provides Incentives } \\
\text { for Teachers }\end{array}$} & $\begin{array}{l}\text { Compliment teachers privately for their } \\
\text { efforts or performance }(50 \%)\end{array}$ & \multirow{5}{*}{$\begin{array}{l}\text { Reinforce superior } \\
\text { performance by teachers } \\
\text { in staff meetings, } \\
\text { newsletters, and/or memos }\end{array}$} \\
\hline & $\begin{array}{l}\text { Reinforce superior performance by teachers in } \\
\text { staff meetings, newsletters, and/or memos } \\
(21.43 \%)\end{array}$ & \\
\hline & $\begin{array}{l}\text { Acknowledge teachers' exceptional } \\
\text { performance by writing memos for their } \\
\text { personnel files }(0 \%)\end{array}$ & \\
\hline & $\begin{array}{l}\text { Reward special efforts by teachers with } \\
\text { opportunities for professional recognition } \\
(7.14 \%)\end{array}$ & \\
\hline & $\begin{array}{l}\text { Create professional growth opportunities for } \\
\text { teachers as a reward for special contributions } \\
\text { to the school }(21.43 \%)\end{array}$ & \\
\hline
\end{tabular}




\begin{tabular}{|c|c|c|}
\hline \multirow[t]{2}{*}{ PIMRS Function } & \multicolumn{2}{|c|}{ Most beneficial activity as perceived by.... } \\
\hline & Teachers & Principal \\
\hline \multirow[t]{5}{*}{$\begin{array}{l}\text { Provides Incentives } \\
\text { for Learning }\end{array}$} & $\begin{array}{l}\text { Support teachers actively in their recognition } \\
\text { and/or reward of student contributions to and } \\
\text { accomplishments in class }(64.29 \%)\end{array}$ & \multirow{5}{*}{$\begin{array}{l}\text { Support teachers actively } \\
\text { in their recognition and/or } \\
\text { reward of student } \\
\text { contributions to and } \\
\text { accomplishments in class }\end{array}$} \\
\hline & $\begin{array}{l}\text { Recognize students who do superior work } \\
\text { with formal rewards such as an honor roll or } \\
\text { mention in the principal's newsletter ( } 14.29 \%)\end{array}$ & \\
\hline & $\begin{array}{l}\text { Use assemblies to honor students for academic } \\
\text { accomplishments or for behavior or } \\
\text { citizenship (21.43\%) }\end{array}$ & \\
\hline & $\begin{array}{l}\text { Recognize superior student achievement or } \\
\text { improvement by seeing in the office the } \\
\text { students with their work }(0 \%)\end{array}$ & \\
\hline & $\begin{array}{l}\text { Contact parents to communicate improved or } \\
\text { exemplary student performance or } \\
\text { contributions }(0 \%)\end{array}$ & \\
\hline \multirow[t]{5}{*}{$\begin{array}{c}\text { Promotes } \\
\text { Professional } \\
\text { Development }\end{array}$} & $\begin{array}{l}\text { Actively support the use in the classroom of } \\
\text { skills acquired during inservice training } \\
(42.86 \%)\end{array}$ & \multirow{5}{*}{$\begin{array}{l}\text { Actively support the use in } \\
\text { the classroom of skills } \\
\text { acquired during inservice } \\
\text { training }\end{array}$} \\
\hline & $\begin{array}{l}\text { Ensure that inservice activities attended by } \\
\text { staff are consistent with the school's goals } \\
(14.29 \%)\end{array}$ & \\
\hline & $\begin{array}{l}\text { Obtain the participation of the whole staff in } \\
\text { important inservice activities }(14.29 \%)\end{array}$ & \\
\hline & $\begin{array}{l}\text { Lead or attend teacher inservice activities } \\
\text { concerned with instruction }(0 \%)\end{array}$ & \\
\hline & $\begin{array}{l}\text { Set aside time at faculty meetings for teachers } \\
\text { to share ideas or information from inservice } \\
\text { activities }(0 \%)\end{array}$ & \\
\hline \multirow[t]{5}{*}{$\begin{array}{l}\text { Maintains High } \\
\text { Visibility }\end{array}$} & $\begin{array}{l}\text { Take time to talk informally with students and } \\
\text { teachers during recess and breaks }(42.86 \%)\end{array}$ & \multirow{5}{*}{$\begin{array}{l}\text { Visit classrooms to } \\
\text { discuss school issues } \\
\text { with teachers and students }\end{array}$} \\
\hline & $\begin{array}{l}\text { Visit classrooms to discuss school issues with } \\
\text { teachers and students }(35.71 \%)\end{array}$ & \\
\hline & $\begin{array}{l}\text { Attend/participate in extra- and co-curricular } \\
\text { activities } \\
(7.14 \%)\end{array}$ & \\
\hline & $\begin{array}{l}\text { Cover classes for teachers until a late or } \\
\text { substitute teacher arrives }(0 \%)\end{array}$ & \\
\hline & $\begin{array}{l}\text { Tutor students or provide direct instruction to } \\
\text { classes }(14.29 \%)\end{array}$ & \\
\hline
\end{tabular}




\section{Instructional Leadership Action Profile: School B}

This document summarizes data collected from your school as part of your participation in a doctoral research project during the 2013-2014 school year. Thank you for your participation.Please contactlah3we@virginia.edu with any questions/concerns.

\section{- Beliefs about Instructional Leadership}

During your interview, you emphasized the following items as critical components of your instructional leadership practice:

- Knowledge

- Support

- Collaboration

- Progress Monitoring

- Visibility

- Impact

The chart to the right shows the frequency of research-based instructional leadership behaviors that

\begin{tabular}{|l|c|}
\hline $\begin{array}{c}\text { PIMRS Domain } \\
\text { (Hallinger \& Murphy, 1985) }\end{array}$ & $\begin{array}{c}\text { Frequency } \\
\text { Mentioned }\end{array}$ \\
\hline Frames the School's Goals & 1 \\
\hline Communicates the School's Goals & 1 \\
\hline Coordinates the Curriculum & 3 \\
\hline Supervises \& Evaluates Instruction & 7 \\
\hline Monitors Student Progress & 8 \\
\hline Protects Instructional Time & 1 \\
\hline Provides Incentives for Teachers & 0 \\
\hline Provides Incentives for Learning & 0 \\
\hline Promotes Professional Development & 1 \\
\hline Maintains High Visibility & 1 \\
\hline
\end{tabular}
were discussed at that time.

\section{- Implementation of Instructional Leadership}

The tables below show the results of the PIMRS 360 Degree survey, administered to you, your teachers, and the division Director of Elementary Education. $65 \%$ of teachers participated in the survey. Note that a score of $1=$ Almost Never and 5=Almost Always.

\begin{tabular}{|l|c|c|c|c|}
\hline \multicolumn{1}{|c|}{ Frames the School Goals } & $\begin{array}{c}\text { Teacher } \\
\text { Mean }\end{array}$ & $\begin{array}{c}\text { Teacher } \\
\text { Mode }\end{array}$ & Self & Dir. \\
\hline Develop a focused set of annual school-wide goals & 3.9 & 5 & 5 & 5 \\
\hline $\begin{array}{l}\text { Frame the school's goals in terms of staff responsibilities for meeting } \\
\text { them }\end{array}$ & 4.1 & 5 & 5 & 5 \\
\hline $\begin{array}{l}\text { Use needs assessment or other formal and informal methods to secure } \\
\text { staff input on goal development }\end{array}$ & 3.6 & 3 & 5 & 4 \\
\hline $\begin{array}{l}\text { Use data on student performance when developing the school's } \\
\text { academic goals }\end{array}$ & 4.5 & 5 & 5 & 5 \\
\hline $\begin{array}{l}\text { Develop goals that are easily understood and used by teachers in the } \\
\text { school }\end{array}$ & 4.1 & 4 & 5 & 5 \\
\hline
\end{tabular}




\begin{tabular}{|l|c|c|c|c|}
\hline \multicolumn{1}{|c|}{ Communicates the School Goals } & $\begin{array}{c}\text { Teacher } \\
\text { Mean }\end{array}$ & $\begin{array}{c}\text { Teacher } \\
\text { Mode }\end{array}$ & Self & Dir. \\
\hline $\begin{array}{l}\text { Communicate the school's mission effectively to members of the } \\
\text { school community }\end{array}$ & 3.4 & 2 & 5 & 5 \\
\hline Discuss the school's academic goals with teachers at faculty meetings & 4.2 & 5 & 5 & 5 \\
\hline $\begin{array}{l}\text { Refer to the school's academic goals when making curricular } \\
\text { decisions with teachers }\end{array}$ & 4.1 & 5 & 5 & 4 \\
\hline $\begin{array}{l}\text { Ensure that the school's academic goals are reflected in highly visible } \\
\text { displays in the school (e.g. posters or bulletin boards emphasizing } \\
\text { academic progress) }\end{array}$ & 3.2 & 3 & 5 & 4 \\
\hline $\begin{array}{l}\text { Refer to the school's goals or mission in forums with students (e.g. in } \\
\text { assemblies or discussions) }\end{array}$ & 2.8 & 2 & 5 & 4 \\
\hline
\end{tabular}

*Results from this function (Supervises and Evaluates Instruction) showed some of the greatest differences between your self-rating and teacher ratings for each activity:

\begin{tabular}{|c|c|c|c|c|}
\hline Supervises \& Evaluates Instruction & $\begin{array}{c}\text { Teacher } \\
\text { Mean }\end{array}$ & $\begin{array}{c}\text { Teacher } \\
\text { Mode }\end{array}$ & Self & Dir. \\
\hline $\begin{array}{l}\text { Ensure that the classroom priorities of teachers are consistent with the } \\
\text { goals and direction of the school }\end{array}$ & 3.8 & 4 & 5 & 5 \\
\hline Review student work products when evaluating classroom instruction & 3.6 & 4 & 5 & 4 \\
\hline $\begin{array}{l}\text { Conduct informal observations in classrooms on a regular basis } \\
\text { (informal observations are unscheduled, last at least } 5 \text { minutes, and } \\
\text { may or may not involve written feedback or a formal conference) }\end{array}$ & 3.3 & 3 & 5 & 4 \\
\hline $\begin{array}{l}\text { Point out specific strengths in teacher's instructional practices in post- } \\
\text { observation feedback (e.g., in conferences or written evaluations) }\end{array}$ & 3.5 & 3 & 5 & 5 \\
\hline $\begin{array}{l}\text { Point out specific weaknesses in teacher instructional practices in } \\
\text { post-observation feedback (e.g., in conferences or written evaluations) }\end{array}$ & 3.4 & 3 & 5 & 5 \\
\hline
\end{tabular}

\begin{tabular}{|l|c|c|c|c|}
\hline \multicolumn{1}{|c|}{ Coordinates the Curriculum } & $\begin{array}{c}\text { Teacher } \\
\text { Mean }\end{array}$ & $\begin{array}{c}\text { Teacher } \\
\text { Mode }\end{array}$ & Self & Dir. \\
\hline $\begin{array}{l}\text { Make clear who is responsible for coordinating the curriculum across } \\
\text { grade levels (e.g., the principal, vice principal, or teacher-leader) }\end{array}$ & 4.1 & 4 & 5 & 5 \\
\hline $\begin{array}{l}\text { Draw upon the results of school-wide testing when making curricular } \\
\text { decisions }\end{array}$ & 4.3 & 4 & 5 & 5 \\
\hline $\begin{array}{l}\text { Monitor the classroom curriculum to see that it covers the school's } \\
\text { curricular objectives }\end{array}$ & 3.8 & 5 & 5 & 5 \\
\hline $\begin{array}{l}\text { Assess the overlap between the school's curricular objectives and the } \\
\text { school's achievement tests }\end{array}$ & 4.1 & 5 & 5 & 4 \\
\hline Participate actively in the review of curricular materials & 3.7 & 4 & 5 & 4 \\
\hline
\end{tabular}




\begin{tabular}{|l|c|c|c|c|}
\hline \multicolumn{1}{|c|}{ Monitors Student Progress } & $\begin{array}{c}\text { Teacher } \\
\text { Mean }\end{array}$ & $\begin{array}{c}\text { Teacher } \\
\text { Mode }\end{array}$ & Self & Dir. \\
\hline Meet individually with teachers to discuss student progress & 3.7 & 3 & 5 & 5 \\
\hline $\begin{array}{l}\text { Discuss academic performance results with the faculty to identify } \\
\text { curricular strengths and weaknesses }\end{array}$ & 4.1 & 5 & 5 & 5 \\
\hline $\begin{array}{l}\text { Use tests and other performance measures to assess progress toward } \\
\text { school goals }\end{array}$ & 4.2 & 5 & 5 & 5 \\
\hline $\begin{array}{l}\text { Inform teachers of the school's performance results in written form } \\
\text { (e.g., in a memo or newsletter) }\end{array}$ & 4.1 & 5 & 5 & 5 \\
\hline Inform students of school's academic progress & 3.2 & 3 & 5 & 4 \\
\hline
\end{tabular}

\begin{tabular}{|l|c|c|c|c|}
\hline \multicolumn{1}{|c|}{ Protects Instructional Time } & $\begin{array}{c}\text { Teacher } \\
\text { Mean }\end{array}$ & $\begin{array}{c}\text { Teacher } \\
\text { Mode }\end{array}$ & Self & Dir. \\
\hline $\begin{array}{l}\text { Limit interruptions of instructional time by public address } \\
\text { announcements }\end{array}$ & 4.4 & 5 & 5 & 4 \\
\hline $\begin{array}{l}\text { Ensure that students are not called to the office during instructional } \\
\text { time }\end{array}$ & 3.9 & 4 & 5 & 4 \\
\hline $\begin{array}{l}\text { Ensure that tardy and truant students suffer specific consequences for } \\
\text { missing instructional time }\end{array}$ & 2.7 & 3 & 5 & 5 \\
\hline $\begin{array}{l}\text { Encourage teachers to use instructional time for teaching and } \\
\text { practicing new skills and concepts }\end{array}$ & 4.6 & 5 & 5 & 5 \\
\hline $\begin{array}{l}\text { Limit the intrusion of extra- and co-curricular activities on } \\
\text { instructional time }\end{array}$ & 4.1 & 5 & 5 & 5 \\
\hline
\end{tabular}

*Results from this function (Maintains High Visibility) showed some of the greatest differences between your self-rating and teacher ratings for each activity:

\begin{tabular}{|l|c|c|c|c|}
\hline \multicolumn{1}{|c|}{ Maintains High Visibility } & $\begin{array}{c}\text { Teacher } \\
\text { Mean }\end{array}$ & $\begin{array}{c}\text { Teacher } \\
\text { Mode }\end{array}$ & Self & Dir. \\
\hline $\begin{array}{l}\text { Take time to talk informally with students and teachers during recess } \\
\text { and breaks }\end{array}$ & 3.6 & 3 & 5 & 4 \\
\hline Visit classrooms to discuss school issues with teachers and students & 3.3 & 3 & 5 & 4 \\
\hline Attend/participate in extra- and co-curricular activities & 3.9 & 5 & 5 & 5 \\
\hline Cover classes for teachers until a late or substitute teacher arrives & 2.4 & 2 & 5 & 3 \\
\hline Tutor students or provide direct instruction to classes & 2.4 & 2 & 5 & 3 \\
\hline
\end{tabular}


*Results from this function (Provides Incentives for Teachers) showed some of the greatest differences between your self-rating and teacher ratings for each activity:

\begin{tabular}{|l|c|c|c|c|}
\hline \multicolumn{1}{|c|}{ Provides Incentives for Teachers } & $\begin{array}{c}\text { Teacher } \\
\text { Mean }\end{array}$ & $\begin{array}{c}\text { Teacher } \\
\text { Mode }\end{array}$ & Self & Dir. \\
\hline $\begin{array}{l}\text { Reinforce superior performance by teachers in staff meetings, } \\
\text { newsletters, and/or memos }\end{array}$ & 2.9 & 3 & 5 & 4 \\
\hline Compliment teachers privately for their efforts or performance & 3.4 & 3 & 5 & 4 \\
\hline $\begin{array}{l}\text { Acknowledge teachers' exceptional performance by writing memos } \\
\text { for their personnel files }\end{array}$ & 2.9 & 3 & 5 & 3 \\
\hline $\begin{array}{l}\text { Reward special efforts by teachers with opportunities for professional } \\
\text { recognition }\end{array}$ & 2.8 & 2 & 5 & 4 \\
\hline $\begin{array}{l}\text { Create professional growth opportunities for teachers as a reward for } \\
\text { special contributions to the school }\end{array}$ & 2.7 & 3 & 5 & 3 \\
\hline
\end{tabular}

\begin{tabular}{|l|c|c|c|c|}
\hline \multicolumn{1}{|c|}{ Promotes Professional Development } & $\begin{array}{c}\text { Teacher } \\
\text { Mean }\end{array}$ & $\begin{array}{c}\text { Teacher } \\
\text { Mode }\end{array}$ & Self & Dir. \\
\hline $\begin{array}{l}\text { Ensure that inservice activities attended by staff are consistent with } \\
\text { the school's goals }\end{array}$ & 3.8 & 3 & 5 & 5 \\
\hline $\begin{array}{l}\text { Actively support the use in the classroom of skills acquired during } \\
\text { inservice training }\end{array}$ & 3.7 & 3 & 5 & 5 \\
\hline $\begin{array}{l}\text { Obtain the participation of the whole staff in important inservice } \\
\text { activities }\end{array}$ & 3.8 & 4 & 5 & 5 \\
\hline $\begin{array}{l}\text { Lead or attend teacher inservice activities concerned with instruction } \\
\text { Set aside time at faculty meetings for teachers to share ideas or } \\
\text { information from inservice }\end{array}$ & 3.7 & 4 & 5 & 4 \\
\hline
\end{tabular}

*Results from this function (Provides Incentives for Learning) showed some of the greatest differences between your self-rating and teacher ratings for each activity:

\begin{tabular}{|c|c|c|c|c|}
\hline Provides Incentives for Learning & $\begin{array}{l}\text { Teacher } \\
\text { Mean }\end{array}$ & $\begin{array}{l}\text { Teacher } \\
\text { Mode }\end{array}$ & Self & Dir. \\
\hline $\begin{array}{l}\text { Recognize students who do superior work with formal rewards such } \\
\text { as an honor roll or mention in the principal's newsletter }\end{array}$ & 3.3 & 3 & 5 & 4 \\
\hline $\begin{array}{l}\text { Use assemblies to honor students for academic accomplishments or } \\
\text { for behavior or citizenship }\end{array}$ & 2.9 & 2 & 5 & 5 \\
\hline $\begin{array}{l}\text { Recognize superior student achievement or improvement by seeing in } \\
\text { the office students with their work }\end{array}$ & 2.7 & 2 & 5 & 5 \\
\hline $\begin{array}{l}\text { Contact parents to communicate improved or exemplary student } \\
\text { performance or contributions }\end{array}$ & 2.8 & 3 & 5 & 5 \\
\hline $\begin{array}{l}\text { Support teachers actively in their recognition and/or reward of student } \\
\text { contributions to and accomplishments in class }\end{array}$ & 3.4 & 4 & 5 & 5 \\
\hline
\end{tabular}




\section{- Improving Teacher Capacity via Instructional Leadership}

The table below shows the specific activities for each research-based instructional leadership category that you and participating teachers felt would be most beneficial for increasing teacher professional capacity. These data were collected from you and from participating teachers as an addendum to the PIMRS Instrument.

\begin{tabular}{|c|c|c|}
\hline \multirow[t]{2}{*}{ PIMRS Function } & \multicolumn{2}{|c|}{ Most beneficial activity as perceived by.... } \\
\hline & Teachers & Principal \\
\hline \multirow[t]{5}{*}{$\begin{array}{l}\text { Frames the } \\
\text { School's Goals }\end{array}$} & $\begin{array}{l}\text { Develop goals that are easily understood and } \\
\text { used by teachers in the school }(5.88 \%)\end{array}$ & \multirow{5}{*}{$\begin{array}{l}\text { Use data on student } \\
\text { performance when } \\
\text { developing the school's } \\
\text { academic goals }\end{array}$} \\
\hline & $\begin{array}{l}\text { Develop a focused set of annual school-wide } \\
\text { goals }(5.88 \%)\end{array}$ & \\
\hline & $\begin{array}{l}\text { Frame the school's goals in terms of staff } \\
\text { responsibilities for meeting them }(5.88 \%)\end{array}$ & \\
\hline & $\begin{array}{l}\text { Use needs assessment or other formal and } \\
\text { informal methods to secure staff input on goal } \\
\text { development }(23.53 \%)\end{array}$ & \\
\hline & $\begin{array}{l}\text { Use data on student performance when } \\
\text { developing the school's academic goals } \\
(58.82 \%)\end{array}$ & \\
\hline \multirow[t]{5}{*}{$\begin{array}{l}\text { Communicates the } \\
\text { School's Goals }\end{array}$} & $\begin{array}{l}\text { Discuss the school's academic goals with } \\
\text { teachers at faculty meetings }(29.41 \%)\end{array}$ & \multirow{5}{*}{$\begin{array}{l}\text { Refer to the school's } \\
\text { academic goals when } \\
\text { making curricular } \\
\text { decisions with teachers }\end{array}$} \\
\hline & $\begin{array}{l}\text { Communicate the school's mission effectively } \\
\text { to members of the school community } \\
(11.76 \%)\end{array}$ & \\
\hline & $\begin{array}{l}\text { Refer to the school's academic goals when } \\
\text { making curricular decisions with teachers } \\
(47.06 \%)\end{array}$ & \\
\hline & $\begin{array}{l}\text { Ensure that the school's academic goals are } \\
\text { reflected in highly visible displays in the } \\
\text { school }(0 \%)\end{array}$ & \\
\hline & $\begin{array}{l}\text { Refer to the school's goals or mission in } \\
\text { forums with students }(11.76 \%)\end{array}$ & \\
\hline \multirow[t]{5}{*}{$\begin{array}{l}\text { Coordinates the } \\
\text { Curriculum }\end{array}$} & $\begin{array}{l}\text { Monitor the classroom curriculum to see that } \\
\text { it covers the school's curricular objectives } \\
(17.65 \%)\end{array}$ & \multirow{5}{*}{$\begin{array}{l}\text { Assess the overlap between } \\
\text { the school's curricular } \\
\text { objectives and the school's } \\
\text { achievement tests }\end{array}$} \\
\hline & $\begin{array}{l}\text { Make clear who is responsible for } \\
\text { coordinating the curriculum across grade } \\
\text { levels }(17.65 \%)\end{array}$ & \\
\hline & $\begin{array}{l}\text { Draw upon the results of school-wide testing } \\
\text { when making curricular decisions }(29.41 \%)\end{array}$ & \\
\hline & $\begin{array}{l}\text { Assess the overlap between the school's } \\
\text { curricular objectives and the school's } \\
\text { achievement tests }(23.53 \%)\end{array}$ & \\
\hline & $\begin{array}{l}\text { Participate actively in the review of curricular } \\
\text { materials }(11.76 \%)\end{array}$ & \\
\hline
\end{tabular}




\begin{tabular}{|c|c|c|}
\hline \multirow[t]{2}{*}{ PIMRS Function } & \multicolumn{2}{|c|}{ Most beneficial activity as perceived by.... } \\
\hline & Teachers & Principal \\
\hline \multirow[t]{5}{*}{$\begin{array}{c}\text { Supervises \& } \\
\text { Evaluates Instruction }\end{array}$} & $\begin{array}{l}\text { Ensure that the classroom priorities of } \\
\text { teachers are consistent with the goals and } \\
\text { direction of the school }(52.94 \%)\end{array}$ & \multirow{5}{*}{$\begin{array}{l}\text { Point out specific } \\
\text { weaknesses in teacher } \\
\text { instructional practices in } \\
\text { post-observation feedback }\end{array}$} \\
\hline & $\begin{array}{l}\text { Review student work products when } \\
\text { evaluating classroom instruction }(5.88 \%)\end{array}$ & \\
\hline & $\begin{array}{l}\text { Conduct informal observations in classrooms } \\
\text { on a regular basis }(17.65 \%)\end{array}$ & \\
\hline & $\begin{array}{l}\text { Point out specific strengths in teacher's } \\
\text { instructional practices in post-observation } \\
\text { feedback }(5.88 \%)\end{array}$ & \\
\hline & $\begin{array}{l}\text { Point out specific weaknesses in teacher } \\
\text { instructional practices in post-observation } \\
\text { feedback }(17.65 \%)\end{array}$ & \\
\hline \multirow[t]{5}{*}{$\begin{array}{l}\text { Monitors Student } \\
\text { Progress }\end{array}$} & $\begin{array}{l}\text { Discuss academic performance results with } \\
\text { the faculty to identify curricular strengths and } \\
\text { weaknesses }(41.18 \%)\end{array}$ & \multirow[t]{5}{*}{$\begin{array}{l}\text { Meet individually with } \\
\text { teachers to discuss student } \\
\text { progress }\end{array}$} \\
\hline & $\begin{array}{l}\text { Meet individually with teachers to discuss } \\
\text { student progress }(35.29 \%)\end{array}$ & \\
\hline & $\begin{array}{l}\text { Use tests and other performance measure to } \\
\text { assess progress toward school goals }(11.76 \%)\end{array}$ & \\
\hline & $\begin{array}{l}\text { Inform teachers of the school's performance } \\
\text { results in written form }(11.76 \%)\end{array}$ & \\
\hline & $\begin{array}{l}\text { Inform students of school's academic progress } \\
(0 \%)\end{array}$ & \\
\hline \multirow[t]{5}{*}{$\begin{array}{l}\text { Protects Instructional } \\
\text { Time }\end{array}$} & $\begin{array}{l}\text { Encourage teachers to use instructional time } \\
\text { for teaching and practicing new skills and } \\
\text { concepts }(47.06 \%)\end{array}$ & \multirow{5}{*}{$\begin{array}{l}\text { Ensure that tardy and } \\
\text { truant students suffer } \\
\text { specific consequences for } \\
\text { missing instructional time }\end{array}$} \\
\hline & $\begin{array}{l}\text { Limit interruptions of instructional time by } \\
\text { public address announcements }(5.88 \%)\end{array}$ & \\
\hline & $\begin{array}{l}\text { Ensure that students are not called to the } \\
\text { office during instructional time }(0 \%)\end{array}$ & \\
\hline & $\begin{array}{l}\text { Ensure that tardy and truant students suffer } \\
\text { specific consequences for missing } \\
\text { instructional time }(29.41 \%)\end{array}$ & \\
\hline & $\begin{array}{l}\text { Limit the intrusion of extra- and co-curricular } \\
\text { activities on instructional time }(17.65 \%)\end{array}$ & \\
\hline \multirow{5}{*}{$\begin{array}{l}\text { Provides Incentives } \\
\text { for Teachers }\end{array}$} & $\begin{array}{l}\text { Compliment teachers privately for their } \\
\text { efforts or performance }(47.06 \%)\end{array}$ & \multirow{5}{*}{$\begin{array}{l}\text { Reinforce superior } \\
\text { performance by teachers } \\
\text { in staff meetings, } \\
\text { newsletters, and/or memos }\end{array}$} \\
\hline & $\begin{array}{l}\text { Reinforce superior performance by teachers in } \\
\text { staff meetings, newsletters, and/or memos } \\
(11.76 \%)\end{array}$ & \\
\hline & $\begin{array}{l}\text { Acknowledge teachers' exceptional } \\
\text { performance by writing memos for their } \\
\text { personnel files }(0 \%)\end{array}$ & \\
\hline & $\begin{array}{l}\text { Reward special efforts by teachers with } \\
\text { opportunities for professional recognition } \\
(23.53 \%)\end{array}$ & \\
\hline & $\begin{array}{l}\text { Create professional growth opportunities for } \\
\text { teachers as a reward for special contributions } \\
\text { to the school }(17.65 \%)\end{array}$ & \\
\hline
\end{tabular}




\begin{tabular}{|c|c|c|}
\hline \multirow[t]{2}{*}{ PIMRS Function } & \multicolumn{2}{|c|}{ Most beneficial activity as perceived by.... } \\
\hline & Teachers & Principal \\
\hline \multirow[t]{5}{*}{$\begin{array}{l}\text { Provides Incentives } \\
\text { for Learning }\end{array}$} & $\begin{array}{l}\text { Support teachers actively in their recognition } \\
\text { and/or reward of student contributions to and } \\
\text { accomplishments in class }(52.94 \%)\end{array}$ & \multirow{5}{*}{$\begin{array}{l}\text { Support teachers actively } \\
\text { in their recognition and/or } \\
\text { reward of student } \\
\text { contributions to and } \\
\text { accomplishments in class }\end{array}$} \\
\hline & $\begin{array}{l}\text { Recognize students who do superior work } \\
\text { with formal rewards such as an honor roll or } \\
\text { mention in the principal's newsletter }(17.65 \%)\end{array}$ & \\
\hline & $\begin{array}{l}\text { Use assemblies to honor students for academic } \\
\text { accomplishments or for behavior or } \\
\text { citizenship (17.65\%) }\end{array}$ & \\
\hline & $\begin{array}{l}\text { Recognize superior student achievement or } \\
\text { improvement by seeing in the office the } \\
\text { students with their work }(5.88 \%)\end{array}$ & \\
\hline & $\begin{array}{l}\text { Contact parents to communicate improved or } \\
\text { exemplary student performance or } \\
\text { contributions }(5.88 \%)\end{array}$ & \\
\hline \multirow[t]{5}{*}{$\begin{array}{c}\text { Promotes } \\
\text { Professional } \\
\text { Development }\end{array}$} & $\begin{array}{l}\text { Actively support the use in the classroom of } \\
\text { skills acquired during inservice training } \\
(6.25 \%)\end{array}$ & \multirow{5}{*}{$\begin{array}{l}\text { Set aside time at faculty } \\
\text { meetings for teachers to } \\
\text { share ideas or information } \\
\text { from inservice activities }\end{array}$} \\
\hline & $\begin{array}{l}\text { Ensure that inservice activities attended by } \\
\text { staff are consistent with the school's goals } \\
(12.50 \%)\end{array}$ & \\
\hline & $\begin{array}{l}\text { Obtain the participation of the whole staff in } \\
\text { important inservice activities }(12.50 \%)\end{array}$ & \\
\hline & $\begin{array}{l}\text { Lead or attend teacher inservice activities } \\
\text { concerned with instruction }(0 \%)\end{array}$ & \\
\hline & $\begin{array}{l}\text { Set aside time at faculty meetings for teachers } \\
\text { to share ideas or information from inservice } \\
\text { activities }(68.75 \%)\end{array}$ & \\
\hline \multirow[t]{5}{*}{$\begin{array}{l}\text { Maintains High } \\
\text { Visibility }\end{array}$} & $\begin{array}{l}\text { Take time to talk informally with students and } \\
\text { teachers during recess and breaks }(29.41 \%)\end{array}$ & \multirow{5}{*}{$\begin{array}{l}\text { Take time to talk } \\
\text { informally with students } \\
\text { and teachers during recess } \\
\text { and breaks }\end{array}$} \\
\hline & $\begin{array}{l}\text { Visit classrooms to discuss school issues with } \\
\text { teachers and students }(47.06 \%)\end{array}$ & \\
\hline & $\begin{array}{l}\text { Attend/participate in extra- and co-curricular } \\
\text { activities }(5.88 \%)\end{array}$ & \\
\hline & $\begin{array}{l}\text { Cover classes for teachers until a late or } \\
\text { substitute teacher arrives }(0 \%)\end{array}$ & \\
\hline & $\begin{array}{l}\text { Tutor students or provide direct instruction to } \\
\text { classes }(17.65 \%)\end{array}$ & \\
\hline
\end{tabular}




\section{Instructional Leadership Action Profile: School C}

This document summarizes data collected from your school as part of your participation in a doctoral research project during the 2013-2014 school year. Thank you for your participation.Please contactlah3we@virginia.edu with any questions/concerns.

\section{- Beliefs about Instructional Leadership}

During your interview, you emphasized the following items as critical components of your instructional leadership practice:

- Knowledge

- Support

- Collaboration

- Progress Monitoring

- Visibility

- Impact

The chart to the right shows the frequency of research-based instructional leadership behaviors that

\begin{tabular}{|l|c|}
\hline $\begin{array}{c}\text { PIMRS Domain } \\
\text { (Hallinger \& Murphy, 1985) }\end{array}$ & $\begin{array}{c}\text { Frequency } \\
\text { Mentioned }\end{array}$ \\
\hline Frames the School's Goals & 2 \\
\hline Communicates the School's Goals & 1 \\
\hline Coordinates the Curriculum & 6 \\
\hline Supervises \& Evaluates Instruction & 8 \\
\hline Monitors Student Progress & 7 \\
\hline Protects Instructional Time & 0 \\
\hline Provides Incentives for Teachers & 0 \\
\hline Provides Incentives for Learning & 0 \\
\hline Promotes Professional Development & 3 \\
\hline Maintains High Visibility & 1 \\
\hline
\end{tabular}
were discussed at that time.

\section{- Implementation of Instructional Leadership}

The tables below show the results of the PIMRS 360 Degree survey, administered to you, your teachers, and the division Director of Elementary Education. 100\% of your teachers participated in the survey. Note that a score of $1=$ Almost Never and 5=Almost Always.

\begin{tabular}{|c|c|c|c|c|}
\hline Frames the School Goals & $\begin{array}{c}\text { Teacher } \\
\text { Mean }\end{array}$ & $\begin{array}{c}\text { Teacher } \\
\text { Mode }\end{array}$ & Self & Dir. \\
\hline Develop a focused set of annual school-wide goals & 4.4 & 5 & 5 & 5 \\
\hline $\begin{array}{l}\text { Frame the school's goals in terms of staff responsibilities for meeting } \\
\text { them }\end{array}$ & 4.4 & 5 & 5 & 5 \\
\hline $\begin{array}{l}\text { Use needs assessment or other formal and informal methods to secure } \\
\text { staff input on goal development }\end{array}$ & 4.2 & 5 & 5 & 4 \\
\hline $\begin{array}{l}\text { Use data on student performance when developing the school's } \\
\text { academic goals }\end{array}$ & 4.5 & 5 & 5 & 5 \\
\hline $\begin{array}{l}\text { Develop goals that are easily understood and used by teachers in the } \\
\text { school }\end{array}$ & 4.3 & 5 & 5 & 5 \\
\hline
\end{tabular}




\begin{tabular}{|l|c|c|c|c|}
\hline \multicolumn{1}{|c|}{ Communicates the School Goals } & $\begin{array}{c}\text { Teacher } \\
\text { Mean }\end{array}$ & $\begin{array}{c}\text { Teacher } \\
\text { Mode }\end{array}$ & Self & Dir. \\
\hline $\begin{array}{l}\text { Communicate the school's mission effectively to members of the } \\
\text { school community }\end{array}$ & 4.3 & 5 & 4 & 5 \\
\hline Discuss the school's academic goals with teachers at faculty meetings & 4.8 & 5 & 4 & 4 \\
\hline $\begin{array}{l}\text { Refer to the school's academic goals when making curricular } \\
\text { decisions with teachers }\end{array}$ & 4.4 & 5 & 5 & 4 \\
\hline $\begin{array}{l}\text { Ensure that the school's academic goals are reflected in highly visible } \\
\text { displays in the school (e.g. posters or bulletin boards emphasizing } \\
\text { academic progress) }\end{array}$ & 3.3 & 3 & 3 & 4 \\
\hline $\begin{array}{l}\text { Refer to the school's goals or mission in forums with students (e.g. in } \\
\text { assemblies or discussions) }\end{array}$ & 3.8 & 4 & 5 & 4 \\
\hline
\end{tabular}

\begin{tabular}{|c|c|c|c|c|}
\hline Supervises \& Evaluates Instruction & $\begin{array}{c}\text { Teacher } \\
\text { Mean }\end{array}$ & $\begin{array}{c}\text { Teacher } \\
\text { Mode }\end{array}$ & Self & Dir. \\
\hline $\begin{array}{l}\text { Ensure that the classroom priorities of teachers are consistent with the } \\
\text { goals and direction of the school }\end{array}$ & 4.5 & 5 & 4 & 4 \\
\hline Review student work products when evaluating classroom instruction & 3.9 & 5 & 4 & 4 \\
\hline $\begin{array}{l}\text { Conduct informal observations in classrooms on a regular basis } \\
\text { (informal observations are unscheduled, last at least } 5 \text { minutes, and } \\
\text { may or may not involve written feedback or a formal conference) }\end{array}$ & 4.6 & 5 & 5 & 4 \\
\hline $\begin{array}{l}\text { Point out specific strengths in teacher's instructional practices in post- } \\
\text { observation feedback (e.g., in conferences or written evaluations) }\end{array}$ & 4.1 & 5 & 5 & 4 \\
\hline $\begin{array}{l}\text { Point out specific weaknesses in teacher instructional practices in } \\
\text { post-observation feedback (e.g., in conferences or written evaluations) }\end{array}$ & 4.4 & 5 & 5 & 4 \\
\hline
\end{tabular}

\begin{tabular}{|l|c|c|c|c|}
\hline \multicolumn{1}{|c|}{ Coordinates the Curriculum } & $\begin{array}{c}\text { Teacher } \\
\text { Mean }\end{array}$ & $\begin{array}{c}\text { Teacher } \\
\text { Mode }\end{array}$ & Self & Dir. \\
\hline $\begin{array}{l}\text { Make clear who is responsible for coordinating the curriculum across } \\
\text { grade levels (e.g., the principal, vice principal, or teacher-leader) }\end{array}$ & 3.9 & 5 & 4 & 5 \\
\hline $\begin{array}{l}\text { Draw upon the results of school-wide testing when making curricular } \\
\text { decisions }\end{array}$ & 4.4 & 5 & 5 & 4 \\
\hline $\begin{array}{l}\text { Monitor the classroom curriculum to see that it covers the school's } \\
\text { curricular objectives }\end{array}$ & 4.1 & 5 & 3 & 4 \\
\hline $\begin{array}{l}\text { Assess the overlap between the school's curricular objectives and the } \\
\text { school's achievement tests }\end{array}$ & 4 & 5 & 4 & 4 \\
\hline Participate actively in the review of curricular materials & 3.9 & 5 & 4 & 4 \\
\hline
\end{tabular}




\begin{tabular}{|l|c|c|c|c|}
\hline \multicolumn{1}{|c|}{ Monitors Student Progress } & $\begin{array}{c}\text { Teacher } \\
\text { Mean }\end{array}$ & $\begin{array}{c}\text { Teacher } \\
\text { Mode }\end{array}$ & Self & Dir. \\
\hline Meet individually with teachers to discuss student progress & 4.2 & 4 & 4 & 5 \\
\hline $\begin{array}{l}\text { Discuss academic performance results with the faculty to identify } \\
\text { curricular strengths and weaknesses }\end{array}$ & 4.2 & 5 & 4 & 5 \\
\hline $\begin{array}{l}\text { Use tests and other performance measures to assess progress toward } \\
\text { school goals }\end{array}$ & 4.6 & 5 & 5 & 5 \\
\hline $\begin{array}{l}\text { Inform teachers of the school's performance results in written form } \\
\text { (e.g., in a memo or newsletter) }\end{array}$ & 3.9 & 3 & 2 & 5 \\
\hline Inform students of school's academic progress & 3.6 & 4 & 3 & 5 \\
\hline
\end{tabular}

\begin{tabular}{|l|c|c|c|c|}
\hline \multicolumn{1}{|c|}{ Protects Instructional Time } & $\begin{array}{c}\text { Teacher } \\
\text { Mean }\end{array}$ & $\begin{array}{c}\text { Teacher } \\
\text { Mode }\end{array}$ & Self & Dir. \\
\hline $\begin{array}{l}\text { Limit interruptions of instructional time by public address } \\
\text { announcements }\end{array}$ & 3.5 & 5 & 5 & 4 \\
\hline $\begin{array}{l}\text { Ensure that students are not called to the office during instructional } \\
\text { time }\end{array}$ & 3.2 & 3 & 3 & 4 \\
\hline $\begin{array}{l}\text { Ensure that tardy and truant students suffer specific consequences for } \\
\text { missing instructional time }\end{array}$ & 2.8 & 2 & 1 & 4 \\
\hline $\begin{array}{l}\text { Encourage teachers to use instructional time for teaching and } \\
\text { practicing new skills and concepts }\end{array}$ & 4.5 & 5 & 5 & 5 \\
\hline $\begin{array}{l}\text { Limit the intrusion of extra- and co-curricular activities on } \\
\text { instructional time }\end{array}$ & 3.4 & 4 & 4 & 4 \\
\hline
\end{tabular}

\begin{tabular}{|l|c|c|c|c|}
\hline \multicolumn{1}{|c|}{ Maintains High Visibility } & $\begin{array}{c}\text { Teacher } \\
\text { Mean }\end{array}$ & $\begin{array}{c}\text { Teacher } \\
\text { Mode }\end{array}$ & Self & Dir. \\
\hline $\begin{array}{l}\text { Take time to talk informally with students and teachers during recess } \\
\text { and breaks }\end{array}$ & 4.6 & 5 & 5 & 4 \\
\hline Visit classrooms to discuss school issues with teachers and students & 4.2 & 5 & 3 & 4 \\
\hline Attend/participate in extra- and co-curricular activities & 4.4 & 5 & 5 & 5 \\
\hline Cover classes for teachers until a late or substitute teacher arrives & 2.3 & 1 & 3 & 3 \\
\hline Tutor students or provide direct instruction to classes & 3.9 & 4 & 4 & 3 \\
\hline
\end{tabular}




\begin{tabular}{|l|c|c|c|c|}
\hline \multicolumn{1}{|c|}{ Provides Incentives for Teachers } & $\begin{array}{c}\text { Teacher } \\
\text { Mean }\end{array}$ & $\begin{array}{c}\text { Teacher } \\
\text { Mode }\end{array}$ & Self & Dir. \\
\hline $\begin{array}{l}\text { Reinforce superior performance by teachers in staff meetings, } \\
\text { newsletters, and/or memos }\end{array}$ & 3.8 & 4 & 4 & 5 \\
\hline Compliment teachers privately for their efforts or performance & 4 & 5 & 4 & 5 \\
\hline $\begin{array}{l}\text { Acknowledge teachers' exceptional performance by writing memos } \\
\text { for their personnel files }\end{array}$ & 3.5 & 5 & 3 & 3 \\
\hline $\begin{array}{l}\text { Reward special efforts by teachers with opportunities for professional } \\
\text { recognition }\end{array}$ & 3.4 & 3 & 3 & 4 \\
\hline $\begin{array}{l}\text { Create professional growth opportunities for teachers as a reward for } \\
\text { special contributions to the school }\end{array}$ & 3.4 & 3 & 3 & 3 \\
\hline
\end{tabular}

\begin{tabular}{|l|c|c|c|c|}
\hline \multicolumn{1}{|c|}{ Promotes Professional Development } & $\begin{array}{c}\text { Teacher } \\
\text { Mean }\end{array}$ & $\begin{array}{c}\text { Teacher } \\
\text { Mode }\end{array}$ & Self & Dir. \\
\hline $\begin{array}{l}\text { Ensure that inservice activities attended by staff are consistent with } \\
\text { the school's goals }\end{array}$ & 4.1 & 5 & 4 & 5 \\
\hline $\begin{array}{l}\text { Actively support the use in the classroom of skills acquired during } \\
\text { inservice training }\end{array}$ & 4.1 & 5 & 4 & 5 \\
\hline $\begin{array}{l}\text { Obtain the participation of the whole staff in important inservice } \\
\text { activities }\end{array}$ & 4.4 & 5 & 4 & 5 \\
\hline Lead or attend teacher inservice activities concerned with instruction & 3.5 & 3 & 5 & 5 \\
\hline $\begin{array}{l}\text { Set aside time at faculty meetings for teachers to share ideas or } \\
\text { information from inservice }\end{array}$ & 4.6 & 5 & 5 & 5 \\
\hline
\end{tabular}

\begin{tabular}{|l|c|c|c|c|}
\hline \multicolumn{1}{|c|}{ Provides Incentives for Learning } & $\begin{array}{c}\text { Teacher } \\
\text { Mean }\end{array}$ & $\begin{array}{c}\text { Teacher } \\
\text { Mode }\end{array}$ & Self & Dir. \\
\hline $\begin{array}{l}\text { Recognize students who do superior work with formal rewards such } \\
\text { as an honor roll or mention in the principal's newsletter }\end{array}$ & 4.3 & 5 & 4 & 5 \\
\hline $\begin{array}{l}\text { Use assemblies to honor students for academic accomplishments or } \\
\text { for behavior or citizenship }\end{array}$ & 3.6 & 3 & 3 & 5 \\
\hline $\begin{array}{l}\text { Recognize superior student achievement or improvement by seeing in } \\
\text { the office students with their work }\end{array}$ & 4.1 & 5 & 4 & 5 \\
\hline $\begin{array}{l}\text { Contact parents to communicate improved or exemplary student } \\
\text { performance or contributions }\end{array}$ & 3.4 & 4 & 4 & 5 \\
\hline $\begin{array}{l}\text { Support teachers actively in their recognition and/or reward of student } \\
\text { contributions to and accomplishments in class }\end{array}$ & 4 & 5 & 4 & 5 \\
\hline
\end{tabular}




\section{- Improving Teacher Capacity via Instructional Leadership}

The table below shows the specific activities for each research-based instructional leadership category that you and participating teachers felt would be most beneficial for increasing teacher professional capacity. These data were collected from you and from participating teachers as an addendum to the PIMRS Instrument.

\begin{tabular}{|c|c|c|}
\hline \multirow[t]{2}{*}{ PIMRS Function } & \multicolumn{2}{|c|}{ Most beneficial activity as perceived by.... } \\
\hline & Teachers & Principal \\
\hline \multirow{5}{*}{$\begin{array}{l}\text { Frames the } \\
\text { School's Goals }\end{array}$} & $\begin{array}{l}\text { Develop goals that are easily understood and } \\
\text { used by teachers in the school }(11.76 \%)\end{array}$ & \multirow{5}{*}{$\begin{array}{l}\text { Use data on student } \\
\text { performance when } \\
\text { developing the school's } \\
\text { academic goals }\end{array}$} \\
\hline & $\begin{array}{l}\text { Develop a focused set of annual school-wide } \\
\text { goals }(29.41 \%)\end{array}$ & \\
\hline & $\begin{array}{l}\text { Frame the school's goals in terms of staff } \\
\text { responsibilities for meeting them }(11.76 \%)\end{array}$ & \\
\hline & $\begin{array}{l}\text { Use needs assessment or other formal and } \\
\text { informal methods to secure staff input on goal } \\
\text { development }(5.88 \%)\end{array}$ & \\
\hline & $\begin{array}{l}\text { Use data on student performance when } \\
\text { developing the school's academic goals } \\
(41.18 \%)\end{array}$ & \\
\hline \multirow[t]{5}{*}{$\begin{array}{l}\text { Communicates the } \\
\text { School's Goals }\end{array}$} & $\begin{array}{l}\text { Discuss the school's academic goals with } \\
\text { teachers at faculty meetings }(43.75 \%)\end{array}$ & \multirow{5}{*}{$\begin{array}{l}\text { Refer to the school's } \\
\text { academic goals when } \\
\text { making curricular } \\
\text { decisions with teachers }\end{array}$} \\
\hline & $\begin{array}{l}\text { Communicate the school's mission effectively } \\
\text { to members of the school community } \\
(12.50 \%)\end{array}$ & \\
\hline & $\begin{array}{l}\text { Refer to the school's academic goals when } \\
\text { making curricular decisions with teachers } \\
(31.25 \%)\end{array}$ & \\
\hline & $\begin{array}{l}\text { Ensure that the school's academic goals are } \\
\text { reflected in highly visible displays in the } \\
\text { school }(0 \%)\end{array}$ & \\
\hline & $\begin{array}{l}\text { Refer to the school's goals or mission in } \\
\text { forums with students }(12.50 \%)\end{array}$ & \\
\hline \multirow[t]{5}{*}{$\begin{array}{l}\text { Coordinates the } \\
\text { Curriculum }\end{array}$} & $\begin{array}{l}\text { Monitor the classroom curriculum to see that } \\
\text { it covers the school's curricular objectives } \\
(37.50 \%)\end{array}$ & \multirow{5}{*}{$\begin{array}{l}\text { Draw upon the results of } \\
\text { school-wide testing when } \\
\text { making curricular } \\
\text { decisions }\end{array}$} \\
\hline & $\begin{array}{l}\text { Make clear who is responsible for } \\
\text { coordinating the curriculum across grade } \\
\text { levels }(12.50 \%)\end{array}$ & \\
\hline & $\begin{array}{l}\text { Draw upon the results of school-wide testing } \\
\text { when making curricular decisions }(25 \%)\end{array}$ & \\
\hline & $\begin{array}{l}\text { Assess the overlap between the school's } \\
\text { curricular objectives and the school's } \\
\text { achievement tests (25\%) }\end{array}$ & \\
\hline & $\begin{array}{l}\text { Participate actively in the review of curricular } \\
\text { materials }(0 \%)\end{array}$ & \\
\hline
\end{tabular}




\begin{tabular}{|c|c|c|}
\hline \multirow[t]{2}{*}{ PIMRS Function } & \multicolumn{2}{|c|}{ Most beneficial activity as perceived by.... } \\
\hline & Teachers & Principal \\
\hline \multirow[t]{5}{*}{$\begin{array}{c}\text { Supervises \& } \\
\text { Evaluates Instruction }\end{array}$} & $\begin{array}{l}\text { Ensure that the classroom priorities of } \\
\text { teachers are consistent with the goals and } \\
\text { direction of the school }(17.65 \%)\end{array}$ & \multirow{5}{*}{$\begin{array}{l}\text { Point out specific } \\
\text { weaknesses in teacher } \\
\text { instructional practices in } \\
\text { post-observation feedback }\end{array}$} \\
\hline & $\begin{array}{l}\text { Review student work products when } \\
\text { evaluating classroom instruction }(11.76 \%)\end{array}$ & \\
\hline & $\begin{array}{l}\text { Conduct informal observations in classrooms } \\
\text { on a regular basis }(29.41 \%)\end{array}$ & \\
\hline & $\begin{array}{l}\text { Point out specific strengths in teacher's } \\
\text { instructional practices in post-observation } \\
\text { feedback }(17.65 \%)\end{array}$ & \\
\hline & $\begin{array}{l}\text { Point out specific weaknesses in teacher } \\
\text { instructional practices in post-observation } \\
\text { feedback }(23.53 \%)\end{array}$ & \\
\hline \multirow[t]{5}{*}{$\begin{array}{l}\text { Monitors Student } \\
\text { Progress }\end{array}$} & $\begin{array}{l}\text { Discuss academic performance results with } \\
\text { the faculty to identify curricular strengths and } \\
\text { weaknesses }(11.76 \%)\end{array}$ & \multirow[t]{5}{*}{$\begin{array}{l}\text { Meet individually with } \\
\text { teachers to discuss student } \\
\text { progress }\end{array}$} \\
\hline & $\begin{array}{l}\text { Meet individually with teachers to discuss } \\
\text { student progress }(58.82 \%)\end{array}$ & \\
\hline & $\begin{array}{l}\text { Use tests and other performance measure to } \\
\text { assess progress toward school goals }(11.76 \%)\end{array}$ & \\
\hline & $\begin{array}{l}\text { Inform teachers of the school's performance } \\
\text { results in written form }(5.88 \%)\end{array}$ & \\
\hline & $\begin{array}{l}\text { Inform students of school's academic progress } \\
(11.76 \%)\end{array}$ & \\
\hline \multirow[t]{5}{*}{$\begin{array}{c}\text { Protects Instructional } \\
\text { Time }\end{array}$} & $\begin{array}{l}\text { Encourage teachers to use instructional time } \\
\text { for teaching and practicing new skills and } \\
\text { concepts }(35.29 \%)\end{array}$ & \multirow{5}{*}{$\begin{array}{l}\text { Encourage teachers to use } \\
\text { instructional time for } \\
\text { teaching and practicing } \\
\text { new skills and concepts }\end{array}$} \\
\hline & $\begin{array}{l}\text { Limit interruptions of instructional time by } \\
\text { public address announcements }(17.65 \%)\end{array}$ & \\
\hline & $\begin{array}{l}\text { Ensure that students are not called to the } \\
\text { office during instructional time }(17.65 \%)\end{array}$ & \\
\hline & $\begin{array}{l}\text { Ensure that tardy and truant students suffer } \\
\text { specific consequences for missing } \\
\text { instructional time }(0 \%)\end{array}$ & \\
\hline & $\begin{array}{l}\text { Limit the intrusion of extra- and co-curricular } \\
\text { activities on instructional time }(29.41 \%)\end{array}$ & \\
\hline \multirow[t]{5}{*}{$\begin{array}{l}\text { Provides Incentives } \\
\text { for Teachers }\end{array}$} & $\begin{array}{l}\text { Compliment teachers privately for their } \\
\text { efforts or performance }(40 \%)\end{array}$ & \multirow{5}{*}{$\begin{array}{l}\text { Reinforce superior } \\
\text { performance by teachers } \\
\text { in staff meetings, } \\
\text { newsletters, and/or memos }\end{array}$} \\
\hline & $\begin{array}{l}\text { Reinforce superior performance by teachers in } \\
\text { staff meetings, newsletters, and/or memos } \\
(20 \%)\end{array}$ & \\
\hline & $\begin{array}{l}\text { Acknowledge teachers' exceptional } \\
\text { performance by writing memos for their } \\
\text { personnel files }(6.67 \%)\end{array}$ & \\
\hline & $\begin{array}{l}\text { Reward special efforts by teachers with } \\
\text { opportunities for professional recognition } \\
(6.67 \%)\end{array}$ & \\
\hline & $\begin{array}{l}\text { Create professional growth opportunities for } \\
\text { teachers as a reward for special contributions } \\
\text { to the school }(26.67 \%)\end{array}$ & \\
\hline
\end{tabular}




\begin{tabular}{|c|c|c|}
\hline \multirow[t]{2}{*}{ PIMRS Function } & \multicolumn{2}{|c|}{ Most beneficial activity as perceived by.... } \\
\hline & Teachers & Principal \\
\hline \multirow[t]{5}{*}{$\begin{array}{l}\text { Provides Incentives } \\
\text { for Learning }\end{array}$} & $\begin{array}{l}\text { Support teachers actively in their recognition } \\
\text { and/or reward of student contributions to and } \\
\text { accomplishments in class }(18.75 \%)\end{array}$ & \multirow{5}{*}{$\begin{array}{l}\text { Support teachers actively } \\
\text { in their recognition and/or } \\
\text { reward of student } \\
\text { contributions to and } \\
\text { accomplishments in class }\end{array}$} \\
\hline & $\begin{array}{l}\text { Recognize students who do superior work } \\
\text { with formal rewards such as an honor roll or } \\
\text { mention in the principal's newsletter }(31.25 \%)\end{array}$ & \\
\hline & $\begin{array}{l}\text { Use assemblies to honor students for academic } \\
\text { accomplishments or for behavior or } \\
\text { citizenship (18.75\%) }\end{array}$ & \\
\hline & $\begin{array}{l}\text { Recognize superior student achievement or } \\
\text { improvement by seeing in the office the } \\
\text { students with their work }(12.50 \%)\end{array}$ & \\
\hline & $\begin{array}{l}\text { Contact parents to communicate improved or } \\
\text { exemplary student performance or } \\
\text { contributions }(18.75 \%)\end{array}$ & \\
\hline \multirow{5}{*}{$\begin{array}{c}\text { Promotes } \\
\text { Professional } \\
\text { Development }\end{array}$} & $\begin{array}{l}\text { Actively support the use in the classroom of } \\
\text { skills acquired during inservice training }(25 \%)\end{array}$ & \multirow{5}{*}{$\begin{array}{l}\text { Actively support the use in } \\
\text { the classroom of skills } \\
\text { acquired during inservice } \\
\text { training }\end{array}$} \\
\hline & $\begin{array}{l}\text { Ensure that inservice activities attended by } \\
\text { staff are consistent with the school's goals } \\
(12.50 \%)\end{array}$ & \\
\hline & $\begin{array}{l}\text { Obtain the participation of the whole staff in } \\
\text { important inservice activities }(0 \%)\end{array}$ & \\
\hline & $\begin{array}{l}\text { Lead or attend teacher inservice activities } \\
\text { concerned with instruction }(0 \%)\end{array}$ & \\
\hline & $\begin{array}{l}\text { Set aside time at faculty meetings for teachers } \\
\text { to share ideas or information from inservice } \\
\text { activities }(62.50 \%)\end{array}$ & \\
\hline \multirow[t]{5}{*}{$\begin{array}{l}\text { Maintains High } \\
\text { Visibility }\end{array}$} & $\begin{array}{l}\text { Take time to talk informally with students and } \\
\text { teachers during recess and breaks }(62.50 \%)\end{array}$ & \multirow{5}{*}{$\begin{array}{l}\text { Visit classrooms to discuss } \\
\text { school issues with teachers } \\
\text { and students }\end{array}$} \\
\hline & $\begin{array}{l}\text { Visit classrooms to discuss school issues with } \\
\text { teachers and students }(31.25 \%)\end{array}$ & \\
\hline & $\begin{array}{l}\text { Attend/participate in extra- and co-curricular } \\
\text { activities }(6.25 \%)\end{array}$ & \\
\hline & $\begin{array}{l}\text { Cover classes for teachers until a late or } \\
\text { substitute teacher arrives }(0 \%)\end{array}$ & \\
\hline & $\begin{array}{l}\text { Tutor students or provide direct instruction to } \\
\text { classes }(0 \%)\end{array}$ & \\
\hline
\end{tabular}




\section{Division Level Action Communications}

In addition to sharing results of the 360 degree intervention and qualitative data collection with principals, I will also share relevant findings with the division Director of Elementary Education. The division report will share information from across school sites that could be helpful to the school division in planning future leadership development centered upon instructional leadership practices. This communication will occur through a written report, shared in its entirety on the following pages. 


\section{Division Instructional Leadership Action Profile}

This document summarizes data collected from your school division as part of your participation in a doctoral research project during the 2013-2014 school year. Please contactlah3we@virginia.edu with any questions/concerns.

\section{- Principal Beliefs about Instructional Leadership}

The (3) elementary school principals that participated in this study emphasized the following items as critical components of their instructional leadership practice:

- Knowledge

- Support

- Collaboration

- Progress Monitoring

- Visibility

- Impact

The chart to the right shows the total frequency of research-based instructional leadership behaviors that were discussed by the principals during interviews.

\begin{tabular}{|l|c|}
\hline \multicolumn{1}{|c|}{$\begin{array}{c}\text { PIMRS Domain } \\
\text { (Hallinger \& Murphy, 1985) }\end{array}$} & $\begin{array}{c}\text { Frequency } \\
\text { Mentioned }\end{array}$ \\
\hline Frames the School's Goals & 4 \\
\hline Communicates the School's Goals & 3 \\
\hline Coordinates the Curriculum & 12 \\
\hline Supervises \& Evaluates Instruction & 20 \\
\hline Monitors Student Progress & 22 \\
\hline Protects Instructional Time & 1 \\
\hline Provides Incentives for Teachers & 1 \\
\hline Provides Incentives for Learning & 1 \\
\hline Promotes Professional Development & 7 \\
\hline Maintains High Visibility & 3 \\
\hline
\end{tabular}

\section{- Principal Implementation of Instructional Leadership}

The tables below show the average results of the PIMRS 360 Degree survey, administered to you, the three principals, and teachers in their schools. $67 \%$ of teachers participated in the survey at School A. 65\% of teachers participated in the survey at School B. 100\% participated in the survey at School C. Note that a score of $1=$ Almost Never and 5=Almost Always.

\begin{tabular}{|c|l|c|c|c|c|}
\hline \multirow{2}{*}{$\begin{array}{c}\text { Defining } \\
\text { the }\end{array}$} & School Site & $\begin{array}{c}\text { Teacher } \\
\text { Mean }\end{array}$ & $\begin{array}{c}\text { Teacher } \\
\text { Mode }\end{array}$ & Principal & Supervisor \\
\cline { 2 - 6 } $\begin{array}{c}\text { School } \\
\text { Mission }\end{array}$ & School A & 4.1 & 4.4 & 4.5 & 4.8 \\
\cline { 2 - 6 } & School B & 3.8 & 3.9 & 5 & 4.6 \\
\cline { 2 - 6 } & School C & 4.2 & 4.7 & 4.6 & 4.5 \\
\hline
\end{tabular}




\begin{tabular}{|c|l|c|c|c|c|}
\hline \multirow{4}{*}{$\begin{array}{c}\text { Managing the } \\
\text { Instructional } \\
\text { Program }\end{array}$} & School Site & $\begin{array}{c}\text { Teacher } \\
\text { Mean }\end{array}$ & $\begin{array}{c}\text { Teacher } \\
\text { Mode }\end{array}$ & Principal & Supervisor \\
\cline { 2 - 6 } & School A & 3.7 & 3.9 & 5 & 4.9 \\
\cline { 2 - 6 } & School B & 3.8 & 4.0 & 5 & 4.7 \\
\cline { 2 - 6 } & School C & 4.2 & 4.7 & 4.1 & 4.4 \\
\hline
\end{tabular}

\begin{tabular}{|c|l|c|c|c|c|}
\hline \multirow{2}{*}{$\begin{array}{c}\text { Developing } \\
\text { the School } \\
\text { Learning } \\
\text { Climate }\end{array}$} & School Site & $\begin{array}{c}\text { Teacher } \\
\text { Mean }\end{array}$ & $\begin{array}{c}\text { Teacher } \\
\text { Mode }\end{array}$ & Principal & Supervisor \\
\cline { 2 - 6 } & School A & 3.1 & 2.9 & 4.6 & 4.5 \\
\cline { 2 - 6 } & School B & 3.3 & 3.3 & 5 & 4.3 \\
\hline
\end{tabular}

\section{- Improving Teacher Capacity via Instructional Leadership}

The table below shows the activities for each research-based instructional leadership category that most teachers felt would be most beneficial for increasing their professional capacity. These data were collected from teachers as an addendum to the PIMRS Instrument.

\begin{tabular}{|c|l|}
\hline $\begin{array}{c}\text { PIMRS Domain } \\
\text { Goals }\end{array}$ & \multicolumn{1}{c|}{$\begin{array}{c}\text { Principal Instructional Leadership Activity } \\
\text { Preferred by Most Participating Teachers }\end{array}$} \\
\hline $\begin{array}{c}\text { Frames the School's } \\
\text { School's Goals }\end{array}$ & $\begin{array}{l}\text { Use data on student performance when developing the school's } \\
\text { academic goals }\end{array}$ \\
\hline $\begin{array}{c}\text { Coordinates the } \\
\text { Curriculum }\end{array}$ & $\begin{array}{l}\text { Monitor the classroom curriculum to see that it covers the } \\
\text { school's curricular objectives }\end{array}$ \\
\hline $\begin{array}{c}\text { Supervises \& } \\
\text { Evaluates Instruction }\end{array}$ & $\begin{array}{l}\text { Ensure that the classroom priorities of teachers are consistent } \\
\text { with the goals and direction of the school }\end{array}$ \\
\hline $\begin{array}{c}\text { Monitors Student } \\
\text { Progress }\end{array}$ & Meet individually with teachers to discuss student progress \\
\hline $\begin{array}{c}\text { Protects Instructional } \\
\text { Time }\end{array}$ & $\begin{array}{l}\text { Encourage teachers to use instructional time for teaching and } \\
\text { practicing new skills and concepts }\end{array}$ \\
\hline $\begin{array}{c}\text { Provides Incentives } \\
\text { for Teachers }\end{array}$ & Compliment teachers privately for their efforts or performance \\
\hline $\begin{array}{c}\text { Provides Incentives } \\
\text { for Learning }\end{array}$ & $\begin{array}{l}\text { Support teachers actively in their recognition and/or reward of } \\
\text { student contributions to and accomplishments in class }\end{array}$ \\
\hline $\begin{array}{c}\text { Promotes Professional } \\
\text { Development }\end{array}$ & $\begin{array}{l}\text { Set aside time at faculty meetings for teachers to share ideas or } \\
\text { information from inservice activities }\end{array}$ \\
\hline $\begin{array}{c}\text { Maintains High Visibility } \\
\text { Take time to talk informally with students and teachers during } \\
\text { recess and breaks }\end{array}$ \\
\hline
\end{tabular}




\section{Appendices}

Appendix A: Principal Interview Protocol

Appendix B: Hallinger \& Murphy's (1985) PIMRS Framework

Appendix C: Permission to Use PIMRS Instrument

Appendix D: Permission to Publish PIMRS Instrument as Appendix

Appendix E: Principal Form of PIMRS Instrument

Appendix F: Teacher Form of PIMRS Instrument

Appendix G: Supervisor Form of PIMRS Instrument

Appendix H: Questions Added to PIMRS Principal Form by Researcher

Appendix I: Questions Added to PIMRS Teacher Form by Researcher

Appendix J: Questions Added to PIMRS Supervisor Form by Researcher 
Appendix A

Principal Interview Protocol

1. Please describe your role in your current work location and the length of time you have served in this capacity at this school.

2. As a school leader, what are your main roles?

3. How would you say you divide your time among these roles?

4. How do you feel about your evaluation being tied to student achievement goals this year?

5. Describe your plans for meeting your student achievement goals.

6. What comes to mind when you hear the term "instructional leadership"?

7. If you had to write a definition of instructional leadership for the dictionary, what would you write?

8. What does instructional leadership look like in your school?

9. Tell me more about the types of activities or tasks that you classify as instructional leadership.

10. How frequently would you say that you engage in instructional leadership tasks?

11. How much time would you estimate that you spend on any instructional leadership tasks in a typical day?

12. What kind of impact do you think instructional leadership has on teaching in your school?

13. What kind of impact do you think instructional leadership has on learning in your school?

14. Can you give an example of an instance where you felt your instructional leadership impacted teaching? Impacted learning? 
15. What value do you see in instructional leadership?

16. Among all of your duties as a school leader, how highly would you rate instructional leadership in your list of priorities? 
Appendix B

Hallinger \& Murphy's (1985) PIMRS Framework

\section{PIMRS Framework}

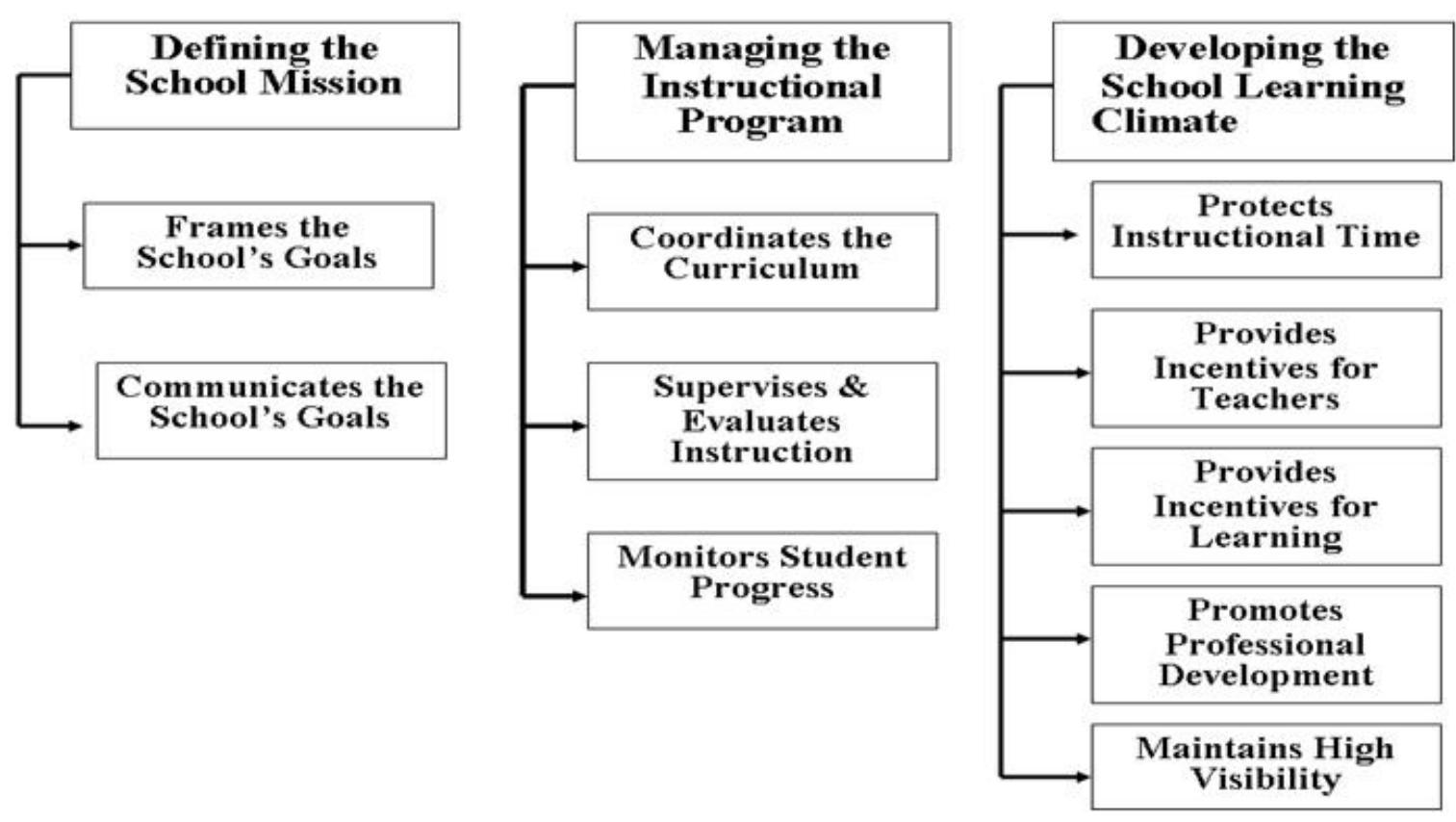


Appendix C

Permission to Use PIMRS Instrument

Dr. Philip Hallinger

7250 Golf Pointe Way

Sarasota, FL 34243

hallinger@gmail.com

October 16, 2013

Leslie Haris

Dear Leslie:

As copyright holder and publisher, you have my permission as publisher to use the Principal Instructional Management Rating Scale (PIMRS) in your research study. In using the scale, you may make unlimited copies of any of the three forms of the PIMRS.

Please note the following conditions of use:

1. This authorization extends only to the use of the PIMRS for research purposes, not for general school district use of the instrument for evaluation or staff development purposes.

2. This is a single-use purchase for the author's graduate research, thereby requiring purchase of additional rights for use in any future research.

3. The user agrees to send a soft copy (pdf) of the completed study to the publisher upon completion of the research.

4. The user agrees to send a soft copy of the data set and coding instructions to the publisher upon completion of the research in order to enable further instrument development.

5. The user has permission to make minor adaptations to scale as necessary for the research.

6. If the instrument is translated, the user will supply a copy of the translated version.

Please be advised that a separate permission to publish letter, usually required by universities, will be sent after the publisher receives a soft copy of the completed study.

Sincerely,

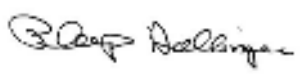

Professor Philip Hallinger 
Appendix D

Permission to Publish PIMRS Instrument as Appendix

\author{
Dr. Philip Hallinger \\ 7250 Golf Pointe Way \\ Sarasota, FL 34243 \\ hallinger@gmail.com
}

April 24, 2014

Leslie Haris

As copyright holder and publisher, you have my permission for Proquest/UMI to include the PIMRS scale in your dissertation which they will publish. I understand that your University may also reproduce single copies and give my assent for that purpose.

Sincerely,

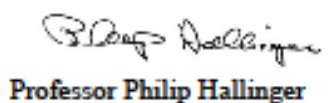

Professor Philip Hallinger 
Appendix E

Principal Form of PIMRS Instrument

\title{
PRINCIPAL INSTRUCTIONAL MANAGEMENT RATING SCALE
}

\author{
Principal Form
}

\author{
Published by: \\ Dr. Philip Hallinger \\ 199/43 Sukhumvit Soi 8 \\ Bangkok, 10110 Thailand \\ www.philiphallinger.com \\ Hallinger@gmail.com
}

\begin{abstract}
All rights are reserved. This instrument may not be reproduced in whole or in part without the written permission of the publisher.
\end{abstract}

Principal Form 2.1 


\section{THE PRINCIPAL INSTRUCTIONAL MANAGEMENT RATING SCALE}

PART I: Please provide the following information if instructed to do so by the person administering the instrument:

(A) District Name:

(B) Your School's Name:

(C) Number of school years you have been principal at this school:

${ }^{1}{ }^{2-4}{ }^{5-9}{ }^{10-15} \quad-$ more than 15

(D) Years, at the end of this school year, that you have been a principal:

$-^{1}{ }^{2-4}-^{10-15} \quad-$ more than 15

(E) Gender: _ Male _ Female

PART II: This questionnaire is designed to provide a profile of your leadership. It consists of 50 behavioral statements that describe principal job practices and behaviors. You are asked to consider each question in terms of your leadership over the past school year.

Read each statement carefully. Then circle the number that best fits the specific job behavior or practice as you conducted it during the past school year. For the response to each statement:

5 represents Almost Always

4 represents Frequently

3 represents Sometimes

2 represents Seldom

1 represents Almost Never

In some cases, these responses may seem awkward; use your judgement in selecting the most appropriate response to such questions. Please circle only one number per question. Try to answer every question.

Thank you. 
To what extent do you ....?

$\begin{array}{ll}\text { ALMOST } & \text { ALMOST } \\ \text { NEVER } & \text { ALWAYS }\end{array}$

\section{FRAME THE SCHOOL GOALS}

1. Develop a focused set of annual school-wide goals

$\begin{array}{lllll}1 & 2 & 3 & 4 & 5 \\ 1 & 2 & 3 & 4 & 5 \\ 1 & 2 & 3 & 4 & 5 \\ 1 & 2 & 3 & 4 & 5 \\ 1 & 2 & 3 & 4 & 5\end{array}$

\section{COMMUNICATE THE SCHOOL GOALS}

6. Communicate the school's mission effectively to members of the school community

7. Discuss the school's academic goals with teachers at faculty meetings

8. Refer to the school's academic goals when making curricular decisions with teachers

9. Ensure that the school's academic goals are reflected in highly visible displays in the school (e.g., posters or bulletin boards emphasizing academic progress)

10. Refer to the school's goals or mission in forums with students (e.g., in assemblies or discussions)

III. SUPERVISE \& EVALUATE INSTRUCTION

11. Ensure that the classroom prionities of teachers are consistent with the goals and direction of the school

12. Review student work products when evaluating classroom instruction

$\begin{array}{lllll}1 & 2 & 3 & 4 & 5 \\ 1 & 2 & 3 & 4 & 5 \\ 1 & 2 & 3 & 4 & 5 \\ 1 & 2 & 3 & 4 & 5 \\ 1 & 2 & 3 & 4 & 5\end{array}$


13. Conduct informal observations in classrooms on a regular basis (informal observations are unscheduled, last at least 5 minutes, and may or may not involve written feedback or a formal conference)

14. Point out specific strengths in teacher's instructional practices in post-observation feedback (e.g., in conferences or written evaluations)

$\begin{array}{lllll}1 & 2 & 3 & 4 & 5 \\ 1 & 2 & 3 & 4 & 5 \\ 1 & 2 & 3 & 4 & 5\end{array}$
practices in post-observation feedback (e.g., in conferences or written evaluations)

\section{COORDINATE THE CURRICULUM}

16. Make clear who is responsible for coordinating the curriculum across grade levels (e.g., the principal, vice principal, or teacher-leaders)

17. Draw upon the results of school-wide testing when making curricular decisions

18. Monitor the classroom curriculum to see that it covers the school's curricular objectives

19. Assess the overlap between the school's curricular objectives and the school's achievement tests

20. Participate actively in the review of curricular materials

$\begin{array}{lllll}1 & 2 & 3 & 4 & 5 \\ 1 & 2 & 3 & 4 & 5 \\ 1 & 2 & 3 & 4 & 5 \\ 1 & 2 & 3 & 4 & 5 \\ 1 & 2 & 3 & 4 & 5\end{array}$

\section{MONITOR STUDENT PROGRESS}

21. Meet individually with teachers to discuss student progress

$\begin{array}{lllll}1 & 2 & 3 & 4 & 5 \\ 1 & 2 & 3 & 4 & 5 \\ 1 & 2 & 3 & 4 & 5\end{array}$


ALMOST

NEVER

24. Inform teachers of the school's performance results in written form (e.g., in a memo or newsletter)

25. Inform students of school's academic progress

\section{PROTECT INSTRUCTIONAL TIME}

26. Limit intemuptions of instructional time by public address announcements

27. Ensure that students are not called to the office during instructional time

28. Ensure that tardy and truant students suffer specific consequences for missing instructional time

29. Encourage teachers to use instructional time for teaching and practicing new skills and concepts

30. Limit the intrusion of extra- and co-curricular activities on instructional time

\section{MAINTAIN HIGH VISIBILITY}

31. Take time to talk informally with students and teachers during recess and breaks

32. Visit classrooms to discuss school issues with teachers and students

33. Attend/participate in extra- and co-cumicular activities

34. Cover classes for teachers until a late or substitute teacher amives

35. Tutor students or provide direct instruction to classes

\section{PROVIDE INCENTIVES FOR TEACHERS}

36. Reinforce superior performance by teachers in staff meetings, newsletters, and/or memos

37. Compliment teachers privately for their efforts or performance
ALMOST

ALWAYS

$\begin{array}{lllll}1 & 2 & 3 & 4 & 5 \\ 1 & 2 & 3 & 4 & 5\end{array}$

$\begin{array}{lllll}1 & 2 & 3 & 4 & 5 \\ 1 & 2 & 3 & 4 & 5 \\ 1 & 2 & 3 & 4 & 5 \\ 1 & 2 & 3 & 4 & 5 \\ 1 & 2 & 3 & 4 & 5\end{array}$

$\begin{array}{lllll}1 & 2 & 3 & 4 & 5\end{array}$

$\begin{array}{lllll}1 & 2 & 3 & 4 & 5\end{array}$

$\begin{array}{lllll}1 & 2 & 3 & 4 & 5\end{array}$

$\begin{array}{lllll}1 & 2 & 3 & 4 & 5\end{array}$

$\begin{array}{lllll}1 & 2 & 3 & 4 & 5\end{array}$ 
ALMOST ALMOST

NEVER ALWAYS

38. Acknowledge teachers' exceptional performance by writing memos for their personnel files

$\begin{array}{lllll}1 & 2 & 3 & 4 & 5 \\ 1 & 2 & 3 & 4 & 5 \\ 1 & 2 & 3 & 4 & 5\end{array}$

IX. PROMOTE PROFESSIONAL DEVELOPMENT

41. Ensure that inservice activities attended by staff are consistent with the school's goals

42. Actively support the use in the classroom of skills acquired during inservice training

43. Obtain the participation of the whole staff in important inservice activities

44. Lead or attend teacher inservice activities concemed with instruction

45. Set aside time at faculty meetings for teachers to share ideas or information from inservice activities

\section{PROVIDE INCENTIVES FOR LEARNING}

46. Recognize students who do superior work with formal rewards such as an honor roll or mention in the principal's newsletter

47. Use assemblies to honor students for academic accomplishments or for behavior or citizenship

48. Recognize superior student achievement or improvement by seeing in the office the students with their work

49. Contact parents to communicate improved or exemplary student performance or contributions

$\begin{array}{lllll}1 & 2 & 3 & 4 & 5 \\ 1 & 2 & 3 & 4 & 5 \\ 1 & 2 & 3 & 4 & 5 \\ 1 & 2 & 3 & 4 & 5 \\ 1 & 2 & 3 & 4 & 5\end{array}$

. Support teachers actively in their recognition and/or reward of student contributions to and accomplishments in class

$\begin{array}{lllll}1 & 2 & 3 & 4 & 5 \\ 1 & 2 & 3 & 4 & 5 \\ 1 & 2 & 3 & 4 & 5 \\ 1 & 2 & 3 & 4 & 5 \\ & & & & \\ 1 & 2 & 3 & 4 & 5\end{array}$




\section{ABOUT THE AUTHOR}

Professor Dr. Philip Hallinger, author of the Principal Instructional Management Rating Scale (PIMRS), received his doctorate in Administration and Policy Analysis from Stanford University. He has worked as a teacher, administrator, and professor and as the director of several leadership development centers. He has been a consultant to education and healthcare organizations throughout the United States, Canada, Asia, and Australia.

The PIMRS was developed with the cooperation of the Milpitas (California) Unified School District, Richard P. Mesa, Superintendent. As a research instrument, it meets professional standards of reliability and validity and has been used in over 200 studies of principal leadership in the United States, Canada, Australia, Europe, and Asia.

The scale is also used by school districts for evaluation and professional development purposes. It surpasses legal standards for use as a personnel evaluation instrument and has been recommended by researchers interested in professional development and district improvement (see, for example, Edwin Bridges, Managing the Incompetent Teacher, ERIC, 1984). Articles on the development and use of the PLMRS have appeared in The Elementary School Joumal, Administrators Notebook, NASSP Bulletin, and Educational Leadership.

The PLMRS is copyrighted and may not be reproduced without the written permission of the author. Additional information on the development of the PIMRS and the rights to its use may be obtained from the publisher (see cover page). 
Appendix F

Teacher Form of PIMRS Instrument

\title{
PRINCIPAL INSTRUCTIONAL MANAGEMENT
}

\section{RATING SCALE}

\section{TEACHER FORM}

\author{
Published by: \\ Dr. Philip Hallinger \\ 199/43 Sukhumvit Soi 8 \\ Bangkok, 10110 Thailand \\ www.philiphallinger.com \\ Hallinger@gmail.com
}




\title{
THE PRINCIPAL INSTRUCTIONAL MANAGEMENT RATING SCALE
}

PART I: Please provide the following information about yourself:

(A) School Name:

(B) Years, at the end of this school year, that you have worked with the current principal:

${ }^{1}{ }^{2-4}-{ }^{5-9}{ }^{10-15} \quad$ more than 15

(C) Years experience as a teacher at the end of this school year.

${ }^{1}{ }^{2-4}-^{5-9} \quad$ - more than 15

(D) Gender of your principal: __ Male __ Female

PART II: This questionnaire is designed to provide a profile of principal leadership. It consists of 50 behavioral statements that describe principal job practices and behaviors. You are asked to consider each question in terms of your observations of the principal's leadership over the past school year.

Read each statement carefully. Then circle the number that best fits the specific job behavior or practice of this principal during the past school year. For the response to each statement:

\author{
5 represents Almost Always \\ 4 represents Frequently \\ 3 represents Sometimes \\ 2 represents Seldom \\ 1 represents Almost Never
}

In some cases, these responses may seem awkward; use your judgment in selecting the most appropriate response to such questions. Please circle only one number per question. Try to answer every question. Thank you. 
To what extent does your principal ...?

$\begin{array}{ll}\text { ALMOST } & \text { ALMOST } \\ \text { NEVER } & \text { ALWAYS }\end{array}$

\section{FRAME THE SCHOOL GOALS}

1. Develop a focused set of annual school-wide goals

$\begin{array}{lllll}1 & 2 & 3 & 4 & 5 \\ 1 & 2 & 3 & 4 & 5 \\ 1 & 2 & 3 & 4 & 5 \\ 1 & 2 & 3 & 4 & 5 \\ 1 & 2 & 3 & 4 & 5\end{array}$

\section{COMMUNICATE THE SCHOOL GOALS}

6. Communicate the school's mission effectively to members of the school community

7. Discuss the school's academic goals with teachers at faculty meetings

8. Refer to the school's academic goals when making curricular decisions with teachers

9. Ensure that the school's academic goals are reflected in highly visible displays in the school (e.g., posters or bulletin boards emphasizing academic progress)

10. Refer to the school's goals or mission in forums with students (e.g., in assemblies or discussions)

\section{SUPERVISE \& EVALUATE INSTRUCTION}

11. Ensure that the classroom prionities of teachers are consistent with the goals and direction of the school

12. Review student work products when evaluating classroom instruction

$\begin{array}{lllll}1 & 2 & 3 & 4 & 5 \\ 1 & 2 & 3 & 4 & 5 \\ 1 & 2 & 3 & 4 & 5 \\ 1 & 2 & 3 & 4 & 5 \\ 1 & 2 & 3 & 4 & 5\end{array}$

$\begin{array}{lllll}1 & 2 & 3 & 4 & 5 \\ 1 & 2 & 3 & 4 & 5\end{array}$


13. Conduct informal observations in classrooms on a regular basis (informal observations are unscheduled,

last at least 5 minutes, and may or may not involve

written feedback or a formal conference)

14. Point out specific strengths in teacher's instructional practices in post-observation feedback (e.g., in conferences or written evaluations)

15. Point out specific weaknesses in teacher instructional practices in post-observation feedback (e.g., in conferences or written evaluations)

\section{COORDINATE THE CURRICULUM}

16. Make clear who is responsible for coordinating the curriculum across grade levels (e.g., the principal, vice principal, or teacher-leaders)

17. Draw upon the results of school-wide testing when making curricular decisions

18. Monitor the classroom curriculum to see that it covers the school's curricular objectives

19. Assess the overlap between the school's curricular objectives and the school's achievement tests

20. Participate actively in the review of curicular materials

$\begin{array}{lllll}1 & 2 & 3 & 4 & 5 \\ 1 & 2 & 3 & 4 & 5 \\ 1 & 2 & 3 & 4 & 5 \\ 1 & 2 & 3 & 4 & 5 \\ 1 & 2 & 3 & 4 & 5\end{array}$

\section{MONITOR STUDENT PROGRESS}

21. Meet individually with teachers to discuss student progress

$\begin{array}{lllll}1 & 2 & 3 & 4 & 5 \\ 1 & 2 & 3 & 4 & 5 \\ 1 & 2 & 3 & 4 & 5\end{array}$


ALMOST

NEVER

24. Inform teachers of the school's performance results in written form (e.g., in a memo or newsletter)

25. Inform students of school's academic progress

\section{PROTECT INSTRUCTIONAL TIME}

26. Limit internuptions of instructional time by public address announcements

27. Ensure that students are not called to the office during instructional time

28. Ensure that tardy and truant students suffer specific consequences for missing instructional time

29. Encourage teachers to use instructional time for teaching and practicing new skills and concepts

30. Limit the intrusion of extra- and co-curricular activities on instructional time

\section{MAINTAIN HIGH VISIBILITY}

31. Take time to talk informally with students and teachers during recess and breaks

32. Visit classrooms to discuss school issues with teachers and students

33. Attend/participate in extra- and co-curricular activities

34. Cover classes for teachers until a late or substitute teacher anives

35. Tutor students or provide direct instruction to classes

VIII. PROVIDE INCENTIVES FOR TEACHERS

36. Reinforce superior performance by teachers in staff meetings, newsletters, and/or memos

37. Compliment teachers privately for their efforts or performance
ALMOST

ALWAYS

$\begin{array}{lllll}1 & 2 & 3 & 4 & 5 \\ 1 & 2 & 3 & 4 & 5\end{array}$

$\begin{array}{lllll}1 & 2 & 3 & 4 & 5 \\ 1 & 2 & 3 & 4 & 5 \\ 1 & 2 & 3 & 4 & 5 \\ 1 & 2 & 3 & 4 & 5 \\ 1 & 2 & 3 & 4 & 5\end{array}$

$\begin{array}{lllll}1 & 2 & 3 & 4 & 5 \\ 1 & 2 & 3 & 4 & 5\end{array}$


38. Acknowledge teachers' exceptional performance by writing memos for their personnel files

39. Reward special efforts by teachers with opportunities for professional recognition

40. Create professional growth opportunities for teachers as a reward for special contributions to the school

\section{PROMOTE PROFESSIONAL DEVELOPMENT}

41. Ensure that inservice activities attended by staff are consistent with the school's goals

42. Actively support the use in the classroom of skills acquired during inservice training

43. Obtain the participation of the whole staff in important inservice activities

44. Lead or attend teacher inservice activities concemed with instruction

45. Set aside time at faculty meetings for teachers to share ideas or information from inservice activities

\section{PROVIDE INCENTIVES FOR LEARNING}

46. Recognize students who do superior work with formal rewards such as an honor roll or mention in the principal's newsletter

47. Use assemblies to honor students for academic accomplishments or for behavior or citizenship

48. Recognize superior student achievement or improvement by seeing in the office the students with their work

49. Contact parents to communicate improved or exemplary student performance or contributions

50. Support teachers actively in their recognition and/or reward of student contributions to and accomplishments in class

$\begin{array}{lllll}1 & 2 & 3 & 4 & 5 \\ 1 & 2 & 3 & 4 & 5 \\ 1 & 2 & 3 & 4 & 5\end{array}$

$\begin{array}{lllll}1 & 2 & 3 & 4 & 5 \\ 1 & 2 & 3 & 4 & 5 \\ 1 & 2 & 3 & 4 & 5 \\ 1 & 2 & 3 & 4 & 5 \\ 1 & 2 & 3 & 4 & 5\end{array}$

$\begin{array}{lllll}1 & 2 & 3 & 4 & 5 \\ 1 & 2 & 3 & 4 & 5 \\ 1 & 2 & 3 & 4 & 5 \\ 1 & 2 & 3 & 4 & 5\end{array}$

$\begin{array}{lllll}1 & 2 & 3 & 4 & 5\end{array}$ 


\section{ABOUT THE AUTHOR}

Professor Dr. Philip Hallinger, author of the Principal Instructional Management Rating Scale (PIMRS), received his doctorate in Administration and Policy Analysis from Stanford University. He has worked as a teacher, administrator, and professor and as the director of several leadership development centers. He has been a consultant to education and healthcare organizations throughout the United States, Canada, Asia, and Australia.

The PLMRS was developed with the cooperation of the Milpitas (California) Unified School District, Richard P. Mesa, Superintendent. As a research instrument, it meets professional standards of reliability and validity and has been used in over 200 studies of principal leadership in the United States, Canada, Australia, Europe, and Asia.

The scale is also used by school districts for evaluation and professional development purposes. It surpasses legal standards for use as a personnel evaluation instrument and has been recommended by researchers interested in professional development and district improvement (see, for example, Edwin Bridges, Managing the Incompetent Teacher, ERIC, 1984). Articles on the development and use of the PLMRS have appeared in The Elementary School Joumal, Administrators Notebook, NASSP Bulletin, and Educational Leadership.

The PIMRS is copyrighted and may not be reproduced without the written permission of the author. Additional information on the development of the PIMRS and the rights to its use may be obtained from the publisher (see cover page). 
Appendix G

Supervisor Form of PIMRS Instrument

\title{
PRINCIPAL INSTRUCTIONAL MANAGEMENT \\ RATING SCALE
}

\section{SUPERVISOR FORM}

\author{
Published by: \\ Dr. Philip Hallinger \\ 199/43 Sukhumvit Soi 8 \\ Bangkok, 10110 Thailand \\ www.philiphallinger.com \\ Hallinger@gmail.com
}




\section{THE PRINCIPAL INSTRUCTIONAL MANAGEMENT RATING SCALE}

PART I: Please provide the following information if instructed to do so by the person administering the instrument:
(A) District Name:
(B) Your Position in the District:
(C) School Name:
(D) Number of school years the principal has been principal at this school:

$-^{1}-^{2-4}-^{10-15} \quad$ more than $15^{\text {m }}$

(E) Years, at the end of this school year, that you have worked with this principal:

- 1 -5-9 _more than 15

$\square^{2-4}-{ }^{10-15}$

(F) Number of visits greater than 20 minutes in length to the principal's school this year.

${ }^{1}{ }^{2-4}{ }^{10-15} \quad$ - more than 15

(G) Gender of the principal: __ Male __ Female

PART II: This questionnaire is designed to provide a profile of principal leadership. It consists of 50 behavioral statements that describe principal job practices and behaviors. You are asked to consider each question in terms of your observations of the principal's leadership over the past school year.

Read each statement carefully. Then circle the number that best fits the specific job behavior or practice of this principal during the past school year. For the response to each statement:

$$
\begin{aligned}
& 5 \text { represents Almost Ahways } \\
& 4 \text { represents Frequently } \\
& 3 \text { represents Sometimes } \\
& 2 \text { represents Seldom } \\
& 1 \text { represents Almost Never }
\end{aligned}
$$

In some cases, these responses may seem awkward; use your judgement in selecting the most appropriate response to such questions. Please circle only one number per question. Try to answer every question. Thank you. 
To what extent does this principal ... ?

$\begin{array}{ll}\text { ALMOST } & \text { ALMOST } \\ \text { NEVER } & \text { ALWAYS }\end{array}$

\section{FRAME THE SCHOOL GOALS}

1. Develop a focused set of annual school-wide goals

$\begin{array}{lllll}1 & 2 & 3 & 4 & 5 \\ 1 & 2 & 3 & 4 & 5 \\ 1 & 2 & 3 & 4 & 5 \\ 1 & 2 & 3 & 4 & 5 \\ 1 & 2 & 3 & 4 & 5\end{array}$

\section{COMMUNICATE THE SCHOOL GOALS}

6. Communicate the school's mission effectively to members of the school community

7. Discuss the school's academic goals with teachers at faculty meetings

8. Refer to the school's academic goals when making curricular decisions with teachers

9. Ensure that the school's academic goals are reflected in highly visible displays in the school (e.g., posters or bulletin boards emphasizing academic progress)

10. Refer to the school's goals or mission in forums with students (e.g., in assemblies or discussions)

\section{SUPERVISE \& EVALUATE INSTRUCTION}

11. Ensure that the classroom prionities of teachers are consistent with the goals and direction of the school

12. Review student work products when evaluating classroom instruction

$\begin{array}{lllll}1 & 2 & 3 & 4 & 5 \\ 1 & 2 & 3 & 4 & 5 \\ 1 & 2 & 3 & 4 & 5 \\ 1 & 2 & 3 & 4 & 5 \\ 1 & 2 & 3 & 4 & 5\end{array}$

$\begin{array}{lllll}1 & 2 & 3 & 4 & 5 \\ 1 & 2 & 3 & 4 & 5\end{array}$


13. Conduct informal observations in classrooms on a

regular basis (informal observations are unscheduled, last at least 5 minutes, and may or may not involve written feedback or a formal conference)

14. Point out specific strengths in teacher's instructional practices in post-observation feedback (e.g., in conferences or written evaluations)

\section{1}

$\begin{array}{llll}2 & 3 & 4 & 5\end{array}$

15. Point out specific weaknesses in teacher instructional practices in post-observation feedback (e.g., in conferences or written evaluations)

\section{COORDINATE THE CURRICULUM}

16. Make clear who is responsible for coordinating the curriculum across grade levels (e.g., the principal, vice principal, or teacher-leaders)

17. Draw upon the results of school-wide testing when making curricular decisions

18. Monitor the classroom curriculum to see that it covers the school's cumicular objectives

19. Assess the overlap between the school's curricular objectives and the school's achievement tests

20. Participate actively in the review of curricular materials

23

4

5

$\begin{array}{lllll}1 & 2 & 3 & 4 & 5\end{array}$

\section{MONITOR STUDENT PROGRESS}

21. Meet individually with teachers to discuss student progress

$\begin{array}{lllll}1 & 2 & 3 & 4 & 5 \\ 1 & 2 & 3 & 4 & 5 \\ 1 & 2 & 3 & 4 & 5\end{array}$


24. Inform teachers of the school's performance results in written form (e.g., in a memo or newsletter)

25. Inform students of school's academic progress

\section{PROTECT INSTRUCTIONAL TIME}

26. Limit interruptions of instructional time by public address announcements

27. Ensure that students are not called to the office during instructional time

28. Ensure that tardy and truant students suffer specific consequences for missing instructional time

29. Encourage teachers to use instructional time for teaching and practicing new skills and concepts

30. Limit the intrusion of extra- and co-curricular activities on instructional time

\section{MAINTAIN HIGH VISIBILITY}

31. Take time to tall informally with students and teachers during recess and breaks

32. Visit classrooms to discuss school issues with teachers and students

33. Attend/participate in extra- and co-curricular activities

34. Cover classes for teachers until a late or substitute teacher anives

35. Tutor students or provide direct instruction to classes

\section{PROVIDE INCENTIVES FOR TEACHERS}

36. Reinforce superior performance by teachers in staff meetings, newsletters, and/or memos

37. Compliment teachers privately for their efforts or performance

$\begin{array}{lllll}1 & 2 & 3 & 4 & 5 \\ 1 & 2 & 3 & 4 & 5\end{array}$

$\begin{array}{lllll}1 & 2 & 3 & 4 & 5 \\ 1 & 2 & 3 & 4 & 5 \\ 1 & 2 & 3 & 4 & 5 \\ 1 & 2 & 3 & 4 & 5 \\ 1 & 2 & 3 & 4 & 5\end{array}$

$\begin{array}{llllll}1 & 2 & 3 & 4 & 5\end{array}$

$\begin{array}{lllll}1 & 2 & 3 & 4 & 5\end{array}$

$\begin{array}{lllll}1 & 2 & 3 & 4 & 5\end{array}$

$\begin{array}{llllll}1 & 2 & 3 & 4 & 5\end{array}$

$\begin{array}{lllll}1 & 2 & 3 & 4 & 5\end{array}$ 
38. Acknowledge teachers' exceptional performance by writing memos for their personnel files

39. Reward special efforts by teachers with opportunities for professional recognition

40. Create professional growth opportunities for teachers as a reward for special contributions to the school

\section{PROMOTE PROFESSIONAL DEVELOPMENT}

41. Ensure that inservice activities attended by staff are consistent with the school's goals

42. Actively support the use in the classroom of skills acquired during inservice training

43. Obtain the participation of the whole staff in important inservice activities

44. Lead or attend teacher inservice activities concemed with instruction

45. Set aside time at faculty meetings for teachers to share ideas or information from inservice activities

\section{PROVIDE INCENTIVES FOR LEARNING}

46. Recognize students who do superior work with formal rewards such as an honor roll or mention in the principal's newsletter

47. Use assemblies to honor students for academic accomplishments or for behavior or citizenship

48. Recognize superior student achievement or improvement by seeing in the office the students with their work

49. Contact parents to communicate improved or exemplary student performance or contributions

50. Support teachers actively in their recognition and/or reward of student contributions to and accomplishments in class

$\begin{array}{lllll}1 & 2 & 3 & 4 & 5 \\ 1 & 2 & 3 & 4 & 5 \\ 1 & 2 & 3 & 4 & 5\end{array}$

$\begin{array}{lllll}1 & 2 & 3 & 4 & 5 \\ 1 & 2 & 3 & 4 & 5 \\ 1 & 2 & 3 & 4 & 5 \\ 1 & 2 & 3 & 4 & 5 \\ 1 & 2 & 3 & 4 & 5\end{array}$

$\begin{array}{lllll}1 & 2 & 3 & 4 & 5\end{array}$

$\begin{array}{lllll}1 & 2 & 3 & 4 & 5\end{array}$

$\begin{array}{lllll}1 & 2 & 3 & 4 & 5\end{array}$

$\begin{array}{lllll}1 & 2 & 3 & 4 & 5\end{array}$




\section{ABOUT THE AUTHOR}

Professor Dr. Philip Hallinger, author of the Principal Instructional Management Rating Scale (PIMRS), received his doctorate in Administration and Policy Analysis from Stanford University. He has worked as a teacher, administrator, and professor and as the director of several leadership development centers. He has been a consultant to education and healthcare organizations throughout the United States, Canada, Asia, and Australia.

The PLMRS was developed with the cooperation of the Milpitas (Califomia) Unified School District, Richard P. Mesa, Superintendent. As a research instrument, it meets professional standards of reliability and validity and has been used in over 200 studies of principal leadership in the United States, Canada, Australia, Europe, and Asia.

The scale is also used by school districts for evaluation and professional development purposes. It surpasses legal standards for use as a personnel evaluation instrument and has been recommended by researchers interested in professional development and district improvement (see, for example, Edwin Bridges, Managing the Incompetent Teacher, ERIC, 1984). Articles on the development and use of the PLMRS have appeared in The Elementary School Joumal, Administrators Notebook, NASSP Bulletin, and Educational Leadership.

The PIMRS is copyrighted and may not be reproduced without the written permission of the author. Additional information on the development of the PIMRS and the rights to its use may be obtained from the publisher (see cover page). 
Appendix $\mathrm{H}$

Questions Added to PIMRS Principal Form by Researcher

5a. Which of your actions related to framing the school goals do you believe is most likely to improve the skill and capacity of your teachers?

- Develop a focused set of annual school-wide goals

- Frame the school's goals in terms of staff responsibilities for meeting them

- Use needs assessment or other formal and informal methods to secure staff input on goal development

- Use data on student performance when developing the school's academic goals

- Develop goals that are easily understood and used by teachers in the school

10a. Which of your actions related to communicating the school goals do you believe is most likely to improve the skill and capacity of your teachers?

- Communicate the school's mission effectively to members of the school community

- Discuss the school's academic goals with teachers at faculty meetings

- Refer to the school's academic goals when making curricular decisions with teachers

- Ensure that the school's academic goals are reflected in highly visible displays in the school (e.g., posters or bulletin boards emphasizing academic progress)

- Refer to the school's goals or mission in forums with students (e.g., in assemblies or discussions)

15a. Which of your actions related to supervising and evaluating instruction do you believe is most likely to improve the skill and capacity of your teachers?

- Ensure that the classroom priorities of teachers are consistent with the goals and direction of the school

- Review student work products when evaluating classroom instruction

- Conduct informal observations in classrooms on a regular basis (informal observations are unscheduled, last at least 5 minutes, and may or may not involve written feedback or a formal conference)

- Point out specific strengths in teacher's instructional practices in postobservation feedback (e.g., in conferences or written evaluations)

- Point out specific weaknesses in teacher instructional practices in postobservation feedback (e.g., in conferences or written evaluations) 
20a. Which of your actions related to coordinating the curriculum do you believe is most likely to improve the skill and capacity of your teachers?

- Make clear who is responsible for coordinating the curriculum across grade levels (e.g., the principal, vice principal, or teacher-leaders)

- Draw upon the results of school-wide testing when making curricular decisions

- Monitor the classroom curriculum to see that it covers the school's curricular objectives

- Assess the overlap between the school's curricular objectives and the school's achievement tests

- Participate actively in the review of curricular materials

25a. Which of your actions related to monitoring student progress do you believe is most likely to improve the skill and capacity of your teachers?

- Meet individually with teachers to discuss student progress

- Discuss academic performance results with the faculty to identify curricular strengths and weaknesses

- Use tests and other performance measure to assess progress toward school goals

- Inform teachers of the school's performance results in written form (e.g., in a memo or newsletter)

- Inform students of school's academic progress

30a. Which of your actions related to protecting instructional time do you believe is most likely to improve the skill and capacity of your teachers?

- Limit interruptions of instructional time by public address announcements

- Ensure that students are not called to the office during instructional time

- Ensure that tardy and truant students suffer specific consequences for missing instructional time

- Encourage teachers to use instructional time for teaching and practicing new skills and concepts

- Limit the intrusion of extra- and co-curricular activities on instructional time

35a. Which of your actions related to maintaining high visibility do you believe is most likely to improve the skill and capacity of your teachers?

- Take time to talk informally with students and teachers during recess and breaks

- Visit classrooms to discuss school issues with teachers and students

- Attend/participate in extra- and co-curricular activities

- Cover classes for teachers until a late or substitute teacher arrives

- Tutor students or provide direct instruction to classes 
40a. Which of your actions related to providing incentives for teachers do you believe is most likely to improve the skill and capacity of your teachers?

- Reinforce superior performance by teachers in staff meetings, newsletters, and/or memos

- Compliment teachers privately for their efforts or performance

- Acknowledge teachers' exceptional performance by writing memos for their personnel files

- Reward special efforts by teachers with opportunities for professional recognition

- Create professional growth opportunities for teachers as a reward for special contributions to the school

45a. Which of your actions related to promoting professional development do you believe is most likely to improve the skill and capacity of your teachers?

- Ensure that inservice activities attended by staff are consistent with the school's goals

- Actively support the use in the classroom of skills acquired during inservice training

- Obtain the participation of the whole staff in important inservice activities

- Lead or attend teacher inservice activities concerned with instruction

- Set aside time at faculty meetings for teachers to share ideas or information from inservice activities

50a. Which of your actions related to providing incentives for learning do you believe is most likely to improve the skill and capacity of your teachers?

- Recognize students who do superior work with formal rewards such as an honor roll or mention in the principal's newsletter

- Use assemblies to honor students for academic accomplishments or for behavior or citizenship

- Recognize superior student achievement or improvement by seeing in the office the students with their work

- Contact parents to communicate improved or exemplary student performance or contributions

- Support teachers actively in their recognition and/or reward of student contributions to and accomplishments in class 
Appendix I

Questions Added to PIMRS Teacher Form by Researcher

5a. Which of these principal actions related to framing the school goals do you believe is most likely to improve your teaching skill and capacity?

- Develop a focused set of annual school-wide goals

- Frame the school's goals in terms of staff responsibilities for meeting them

- Use needs assessment or other formal and informal methods to secure staff input on goal development

○ Use data on student performance when developing the school's academic goals

- Develop goals that are easily understood and used by teachers in the school

10a. Which of these principal actions related to communicating the school goals do you believe is most likely to improve your teaching skill and capacity?

○ Communicate the school's mission effectively to members of the school community

- Discuss the school's academic goals with teachers at faculty meetings

- Refer to the school's academic goals when making curricular decisions with teachers

- Ensure that the school's academic goals are reflected in highly visible displays in the school (e.g., posters or bulletin boards emphasizing academic progress)

○ Refer to the school's goals or mission in forums with students (e.g., in assemblies or discussions)

\section{5a. Which of these principal actions related to supervising and evaluating} instruction do you believe is most likely to improve your teaching skill and capacity?

- Ensure that the classroom priorities of teachers are consistent with the goals and direction of the school

- Review student work products when evaluating classroom instruction

- Conduct informal observations in classrooms on a regular basis (informal observations are unscheduled, last at least 5 minutes, and may or may not involve written feedback or a formal conference)

○ Point out specific strengths in teacher's instructional practices in postobservation feedback (e.g., in conferences or written evaluations)

- Point out specific weaknesses in teacher instructional practices in postobservation feedback (e.g., in conferences or written evaluations) 
20a. Which of these principal actions related to coordinating the curriculum do you believe is most likely to improve your teaching skill and capacity?

- Make clear who is responsible for coordinating the curriculum across grade levels (e.g., the principal, vice principal, or teacher-leaders)

- Draw upon the results of school-wide testing when making curricular decisions

- Monitor the classroom curriculum to see that it covers the school's curricular objectives

- Assess the overlap between the school's curricular objectives and the school's achievement tests

- Participate actively in the review of curricular materials

25a. Which of these principal actions related to monitoring student progress do you believe is most likely to improve your teaching skill and capacity?

- Meet individually with teachers to discuss student progress

- Discuss academic performance results with the faculty to identify curricular strengths and weaknesses

- Use tests and other performance measure to assess progress toward school goals

- Inform teachers of the school's performance results in written form (e.g., in a memo or newsletter)

- Inform students of school's academic progress

30a. Which of these principal actions related to protecting instructional time do you believe is most likely to improve your teaching skill and capacity?

- Limit interruptions of instructional time by public address announcements

- Ensure that students are not called to the office during instructional time

- Ensure that tardy and truant students suffer specific consequences for missing instructional time

- Encourage teachers to use instructional time for teaching and practicing new skills and concepts

- Limit the intrusion of extra- and co-curricular activities on instructional time

35a. Which of these principal actions related to maintaining high visibility do you believe is most likely to improve your teaching skill and capacity?

- Take time to talk informally with students and teachers during recess and breaks

- Visit classrooms to discuss school issues with teachers and students

- Attend/participate in extra- and co-curricular activities

- Cover classes for teachers until a late or substitute teacher arrives

- Tutor students or provide direct instruction to classes 
40a. Which of these principal actions related to providing incentives for teachers do you believe is most likely to improve your teaching skill and capacity?

- Reinforce superior performance by teachers in staff meetings, newsletters, and/or memos

- Compliment teachers privately for their efforts or performance

○ Acknowledge teachers' exceptional performance by writing memos for their personnel files

- Reward special efforts by teachers with opportunities for professional recognition

- Create professional growth opportunities for teachers as a reward for special contributions to the school

45a. Which of these principal actions related to promoting professional development do you believe is most likely to improve your teaching skill and capacity?

- Ensure that inservice activities attended by staff are consistent with the school's goals

- Actively support the use in the classroom of skills acquired during inservice training

- Obtain the participation of the whole staff in important inservice activities

- Lead or attend teacher inservice activities concerned with instruction

- Set aside time at faculty meetings for teachers to share ideas or information from inservice activities

50a. Which of these principal actions related to providing incentives for learning do you believe is most likely to improve your teaching skill and capacity?

- Recognize students who do superior work with formal rewards such as an honor roll or mention in the principal's newsletter

- Use assemblies to honor students for academic accomplishments or for behavior or citizenship

- Recognize superior student achievement or improvement by seeing in the office the students with their work

- Contact parents to communicate improved or exemplary student performance or contributions

- Support teachers actively in their recognition and/or reward of student contributions to and accomplishments in class 
Appendix J

Questions Added to PIMRS Supervisor Form by Researcher

5a. Which of a principal's actions related to framing the school goals do you believe is most likely to improve teacher skill and capacity?

- Develop a focused set of annual school-wide goals

- Frame the school's goals in terms of staff responsibilities for meeting them

- Use needs assessment or other formal and informal methods to secure staff input on goal development

○ Use data on student performance when developing the school's academic goals

- Develop goals that are easily understood and used by teachers in the school

10a. Which of a principal's actions related to communicating the school goals do you believe is most likely to improve teacher skill and capacity?

○ Communicate the school's mission effectively to members of the school community

- Discuss the school's academic goals with teachers at faculty meetings

- Refer to the school's academic goals when making curricular decisions with teachers

- Ensure that the school's academic goals are reflected in highly visible displays in the school (e.g., posters or bulletin boards emphasizing academic progress)

○ Refer to the school's goals or mission in forums with students (e.g., in assemblies or discussions)

15a. Which of a principal's actions related to supervising and evaluating instruction do you believe is most likely to improve teacher skill and capacity?

Ensure that the classroom priorities of teachers are consistent with the goals and direction of the school

- Review student work products when evaluating classroom instruction

- Conduct informal observations in classrooms on a regular basis (informal observations are unscheduled, last at least 5 minutes, and may or may not involve written feedback or a formal conference)

○ Point out specific strengths in teacher's instructional practices in postobservation feedback (e.g., in conferences or written evaluations)

- Point out specific weaknesses in teacher instructional practices in postobservation feedback (e.g., in conferences or written evaluations) 
20a. Which of a principal's actions related to coordinating the curriculum do you believe is most likely to improve teacher skill and capacity?

- Make clear who is responsible for coordinating the curriculum across grade levels (e.g., the principal, vice principal, or teacher-leaders)

- Draw upon the results of school-wide testing when making curricular decisions

- Monitor the classroom curriculum to see that it covers the school's curricular objectives

- Assess the overlap between the school's curricular objectives and the school's achievement tests

- Participate actively in the review of curricular materials

25a. Which of a principal's actions related to monitoring student progress do you believe is most likely to improve teacher skill and capacity?

- Meet individually with teachers to discuss student progress

- Discuss academic performance results with the faculty to identify curricular strengths and weaknesses

- Use tests and other performance measure to assess progress toward school goals

- Inform teachers of the school's performance results in written form (e.g., in a memo or newsletter)

- Inform students of school's academic progress

30a. Which of a principal's actions related to protecting instructional time do you believe is most likely to improve teacher skill and capacity?

- Limit interruptions of instructional time by public address announcements

- Ensure that students are not called to the office during instructional time

- Ensure that tardy and truant students suffer specific consequences for missing instructional time

- Encourage teachers to use instructional time for teaching and practicing new skills and concepts

- Limit the intrusion of extra- and co-curricular activities on instructional time

35a. Which of a principal's actions related to maintaining high visibility do you believe is most likely to improve teacher skill and capacity?

- Take time to talk informally with students and teachers during recess and breaks

- Visit classrooms to discuss school issues with teachers and students

- Attend/participate in extra- and co-curricular activities

- Cover classes for teachers until a late or substitute teacher arrives

- Tutor students or provide direct instruction to classes 
40a. Which of a principal's actions related to providing incentives for teachers do you believe is most likely to improve teacher skill and capacity?

- Reinforce superior performance by teachers in staff meetings, newsletters, and/or memos

- Compliment teachers privately for their efforts or performance

○ Acknowledge teachers' exceptional performance by writing memos for their personnel files

- Reward special efforts by teachers with opportunities for professional recognition

- Create professional growth opportunities for teachers as a reward for special contributions to the school

45a. Which of a principal's actions related to promoting professional development do you believe is most likely to improve teacher skill and capacity?

- Ensure that inservice activities attended by staff are consistent with the school's goals

- Actively support the use in the classroom of skills acquired during inservice training

- Obtain the participation of the whole staff in important inservice activities

- Lead or attend teacher inservice activities concerned with instruction

- Set aside time at faculty meetings for teachers to share ideas or information from inservice activities

50a. Which of a principal's actions related to providing incentives for learning do you believe is most likely to improve teacher skill and capacity?

- Recognize students who do superior work with formal rewards such as an honor roll or mention in the principal's newsletter

- Use assemblies to honor students for academic accomplishments or for behavior or citizenship

- Recognize superior student achievement or improvement by seeing in the office the students with their work

○ Contact parents to communicate improved or exemplary student performance or contributions

- Support teachers actively in their recognition and/or reward of student contributions to and accomplishments in class 


\section{References}

Airola, D.T. \& Dunn, K.E. (2011). Oregon DATA project final evaluation report. Fayetteville, AR: Next Level Evaluation, Inc.

Alig-Mielcarek, J.M. \& Hoy, W.K. (2005). Instructional leadership: its nature, meaning, and influence. In Miskel, C.G. \& Hoy, W.K. (Eds.). Educational Leadership and Reform. Greenwich, CT: Information Age Publishing, pp. 29-51.

Andrews, R. L., Basom, M. R., \& Basom, M. (1991). Instructional leadership: Supervision that makes a difference. Theory into Practice, 30(2), 97-101.

Andrews, R. L., \& Soder, R. (1987). Principal leadership and student behavior. Educational Leadership, 6, 9-11.

Argyris, C. (1980). Inner contradictions of rigorous research. New York: Academic Press.

Argyris, C. (1987). Reasoning, action strategies, and defensive routines: The case of OD practitioners. In Woodman, R. A. \& Pasmore, A.A. (Eds.). Research in organizational change and development. Greenwich: JAI Press, p. 89-128.

Argyris, C., Putnam, R., \& McLain Smith, D. (1985). Action science: concepts, methods, and skills for research and intervention. San Francisco: Jossey-Bass.

Argyris, C., \& Schõn, D. (1974). Theory in practice: Increasing professional effectiveness. San Francisco: Jossey-Bass.

Argyris, C., \& Schön, D. (1978). Organizational learning: A theory of action perspective, Reading, MA: Addison Wesley.

Atwater, L. E., \& Yammarino, F. J. (1992). Does self-other agreement on leadership perceptions moderate the validity of leadership and performance predictions? Personnel Psychology, 45, 141-164.

Avolio, B.J. (2005), Leadership Development in Balance: MADE/Born. Mahwah, NJ: Lawrence Erlbaum Associates.

Bambrick-Santoyo, P. (2012). Perfecting practice. Phi Delta Kappan, 94(1), 70-71. 
Bamburg, J. \& Andrews, R. (1990). School goals, principals and achievement. School Effectiveness and School Improvement, 2(3), 175-191.

Barth, R. (1986). On sheep and goats and school reform. Phi Delta Kappan, 68(4), 293296.

Barth, R. (2001). Teacher leader. Phi Delta Kappan, 82(6), 443-449.

Bass, B. M., \& Riggio, R. E. (2006). Transformational leadership (Second ed.). Mahwah, NJ: Lawrence Erlbaum Associates.

Bell, L., Bolam, R., \& Cubillo, L. (2003). A systematic review of the impact of school headteachers and principals on student outcomes. London: EPPI-Centre, Social Science Research Unit, Institute of Education.

Bergman, J. Z., Rentsch, J. R., Small, E. E., Davenport, S.W., \& Bergman, S. M. (2012). The shared leadership process in decision-making teams. The Journal of Social Psychology, 152(1), 17-42. PMID 22308759.

Blase, J., \& Blase, J. (2000). Effective instructional leadership: teachers' perspectives on how principals promote teaching and learning in schools. Journal of Educational Administration, 38(2), 130-41.

Blase, J., \& Blase, J. (2003). Handbook of instructional leadership: How successful principals promote teaching and learning. Thousand Oaks, CA: Corwin Press.

Borko, H. (2004). Professional development and teacher learning: Mapping the terrain. Educational Researcher, 33(8), 3-15.

Bossert, S., Dwyer, D., Rowan, B., \& Lee, G. (1982). The instructional management role of the principal. Educational Administration Quarterly, 18(3), 34-64.

Boudett, K.P., Steele, J.L. (Eds) (2007). Data wise in action: Stories of schools using data to improve teaching and learning. Cambridge, MA: Harvard Education Press.

Bridges, E. (1982). Research on the school administrator: The state-of-the-art, 19671980. Educational Administration Quarterly, 18(3), 12-33.

Brutus, S., London, M., \& Martineau, J. (1999). The impact of 360-degree feedback on planning for career development. Journal of Management Development, 8(8), 676-93.

Bryk, A. (2010). Organizing schools for improvement. Phi Delta Kappan, 91(7), 23-30.

Burns, J.M. (1978). Leadership. New York: Harper \& Rowe. 
Byrne, J. (1991, April). CEO disease. Business Week, 52-59.

Church, A. H. (2000). Do higher performing managers actually receive better ratings? A validation of multi-rater assessment methodology. Consulting Psychology Journal: Practice and Research, 54, 166-172.

Church, A. H., \& Waclawski, J. (1999). Influence behaviors and managerial effectiveness in lateral relations. Human Resource Development Quarterly, 10(1), 3-34.

Coggshall, J.G., Rasmussen, C., Colton, A., Milton, J. \& Jacques, C. (2012). Generating teaching effectiveness: The role of job-embedded professional learning in teacher evaluation. Research \& Policy Brief. Washington DC: National Comprehensive Center for Teacher Quality.

Cohen, L., Manion, L., \& Morrison, K. (2007). Research methods in education. London: Routledge Falmer.

Cohen, E., \& Miller, R. (1980). Coordination and control of instruction in schools. Pacific Sociological Review, 4, 446-473.

Collins, A., \& Stevens, A. L. (1983). A cognitive theory of inquiry teaching. In C. M. Reigeluth (Ed.), Instructional design theories and models. An overview of their current status, Hillsdale, NJ: Lawrence Erlbaum.

Chrislip, D. (2002). The collaborative leadership fieldbook: A guide for citizens and civic leaders. San Francisco: Jossey-Bass.

Clough, P. \& Nutbrown, C. (2007). A student's guide to methodology: Justifying enquiry. London: Sage Publications.

Crotty, M. (1998). The foundations of social research. London: SAGE Publications.

Cuban, L. (1984). Transforming the frog into a prince: Effective schools research, policy, and practice at the district level. Harvard Educational Review, 54(2), 128-151.

Darling-Hammond, L. (2012). Creating a comprehensive system for evaluating and supporting effective teaching. Stanford, CA: Stanford Center for Opportunity Policy in Education

Davies, B., Ellison, L., \& Bowring-Carr, C. (2005). School leadership in the 21st century: Developing a strategic approach. London: Routledge-Falmer.

Denscombe, M. (2007). The good research guide: For small-scale social research. Buckingham: Open University Press. 
Dey, I. (1999).Grounding grounded theory: Guidelines for qualitative inquiry. San Diego, CA: Academic Press.

Donaldson, G. A. (2001). Cultivating leadership in schools: Connecting people, purpose, and practice. New York: Teachers College Press.

Duke, D. (2013). Are we pushing for greatness? Phi Delta Kappan, 94(5), 45-49.

Dwyer, D. (1984). The search for instructional leadership: routines and subtleties in the principal's role. Educational Leadership, 41(5), 32-37.

Dwyer, D. (1986). Understanding the principal's contribution to instruction. Peabody Journal of Education, 63(1), 3-18.

Edmonds, R. (1979). Effective schools for the urban poor. Educational Leadership, 37, 15-24.

Edmonds, R. (1981). Programs of school improvement: An overview. Educational Leadership, 40(3), 4-11.

Elmore, R.F. (2004). School reform from the inside out: Policy, practice, and performance. Cambridge, MA: Harvard Education Press.

Eraut, M., \& Hirsh, W. (2007). The significance of workplace learning for individuals, groups, and organisations. Oxford: University of Oxford, SKOPE.

Foriska, T. J. (1994). The principal as instructional leader: Teaming with teachers for student success. Schools in the Middle, 3(3), 31-34.

Frase, L.E. (2001). Constructive feedback on teaching is missing. Education, 113, 176181.

Fullan, M. (2006). The development of transformational leaders for educational decentralization. Toronto, Canada: Author.

Glasman, N. (1984). Student achievement and the school principal. Educational Evaluation and Policy Analysis, 6(3), 283-296.

Goldring, E., Huff, J., May, H., \& Camburn, E. (2008). School context and individual characteristics: What influences principal practice? Journal of Educational Administration, 46(3), 332-352. doi: 10.1108/09578230810869275

Goldring E., \& Pasternak, R. (1994). Principals' coordinating strategies and school effectiveness. School Effectiveness and School Improvement, 5(3), 239-253.

Goldstein, J. (2007). Easy to dance to: Solving the problems of teacher evaluation with 
peer assistance and review. American Journal of Education, 113, 479-508.

Gomm, R. (2004). Social research methodology: A critical introduction. Hampshire, England: Palgrave Macmillan.

Gross, N., \& Herriot, R. (1965). Staff leadership in schools. New York: Wiley.

Hall, G. \& Hord, S. (2002). Implementing change: Patterns, principles, and potholes. Boston, MA: Allyn \& Bacon.

Hallinger, P. (1983). Assessing the instructional management behavior of principals. Unpublished doctoral dissertation, Stanford University, Stanford, CA. ERIC Document No. 8320806.

Hallinger, P. (2011). Leadership for learning: Lessons from 40 years of empirical research. Journal of Educational Administration, 49(2), 125-142.

Hallinger, P. \& Heck, R.H. (1996). Reassessing the principal's role in school effectiveness: A review of empirical research, 1980-1995. Educational Administration Quarterly, 32(1), 5-44.

Hallinger, P., \& Heck, R. H. (2010). Collaborative leadership and school improvement: Understanding the impact on school capacity and student learning. School Leadership and Management, 30(2), 95-110.

Hallinger, P., \& Murphy, J. (1985). Assessing the instructional leadership behavior of principals. Elementary School Journal, 86(2), 217-248.

Harris, M., \& Schaubroech, J. (1988). A metaanalysis of self-supervisor, self-peer, and peer-supervisor ratings. Personnel Psychology, 41, 43-62.

Hattie, J. \& Timperley, H. (2007). The power of feedback. Review of Educational Research, 77, 81-112.

Heck, R. (1992). Principal instructional leadership and the identification of high- and low-achieving schools: The application of discriminant techniques. Administrator's Notebook, 34(7), 1-4.

Hoer, T.R. (1996). Collegiality: A new way to define instructional leadership. Phi Delta Kappan, 77(5), 380-381.

Hong, L.K. (2001). Too many intrusions on instructional time. Phi Delta Kappan, 82(9), 712-714.

Horng, E. L., Klasik, D., \& Loeb, S. (2009). Principal time-use and school effectiveness. 
(School Leadership Research Report No. 09-3). Stanford, CA: Stanford University, Institute for Research on Education Policy \& Practice.

Ing, M. (2010). Using informal classroom observations to improve instruction. Journal of Educational Administration, 48(3), 337-358.

James, M. \& McCormick, R. (2009). Teachers learning how to learn. Teaching and Teacher Education, 25, 973-982.

Joyce, B., \& Calhoun, E. (1996). Learning experiences in school renewal. Eugene, Ore: ERIC Clearinghouse on Educational Management.

Kantabutra, S., \& Avery, G.C. (2005). Essence of shared vision: empirical investigation. New Zealand Journal of Human Resource Management, 5, 1-28.

Kanter, R. M. (1994). Collaborative advantage: The art of alliances. Harvard Business Review, 72(4), 96-108.

Klein, H.J., Wesson, M.J., Hollenbeck, J.R., \& Alge, B.J. (1999). Goal commitment and the goal-setting process: Conceptual clarification and empirical synthesis. Journal of Applied Psychology, 84(6), 885-96.

Kotter, J.P. (1999), What leaders really do? Boston: MA: Harvard Business School Press.

Krug, S. (1992). Instructional leadership: A constructivist perspective. Educational Administration Quarterly, 28(3), 430-443.

Kurland, H., Peretz, H., \& Hertz-Lazarowitz, R. (2010). Leadership style and organizational learning: the mediate effect of school vision. Journal of Educational Administration, 48(1), 7-30. doi: 10.1108/09578231011015395.

Lambert, L. (2002). A framework for shared leadership. Educational Leadership, 59(8), $37-40$.

Leithwood, K. (1994). Leadership for school restructuring. Educational Administration Quarterly, 30(4), 498-518.

Leithwood, K., Anderson, S., Mascall, B., \& Strauss, T. (2011). School leaders' influences on student learning: The four paths. In T. Bush, L., Bell and D. Middlewood (Eds.), The principles of educational leadership and management. London: Sage Publishers.

Leithwood, K., Day, C., Sammons, P., Harris, A., \& Hopkins, D. (2006). Seven strong 
claims about successful school leadership. National College of School Leadership, Nottingham, UK.

Leithwood, K. \& Jantzi, D. (2000). The effects of transformational leadership on organizational conditions and student engagement with the school. Journal of Educational Administration, 38(2), 112-129.

Levin, M.L. (2000). Vision revisited. The Journal of Applied Behavioral Science, 36, 91107.

Licata, J. and Harper, G. (2001). Organisational health and robust school vision. Education Administration Quarterly, 37, pp. 5-26.

Lipham, J. (1961), Effective principal, effective school. Reston, VA: National Association of Secondary School Principals,

Little, J. W. (1982). Norms of collegiality and experimentation: Workplace conditions of school success. American Educational Research Journal, 19(3), 325-340.

Locke, E. A., \& colleagues (2001). The importance of the individual in an age of groupism. In M. Turner (Ed), Groups at work: Theory and research. Mahwah, NJ: L Erlbaum.

Locke, E.A., Kirkpatrick, S., Wheeler, J.K., Schneider, J., Niles, K., Goldstein, H., Welsh, K., \& Chah, D.O. (1991). The essence of leadership. New York: Lexington Books.

Locke, E.A., \& Latham, G.P. (1990). A Theory of goal-setting and task performance. Englewood Cliffs, NJ: Prentice Hall.

London, M. (2002), Leadership Development: Paths to Self-insight and Professional Growth. Mahwah, NJ: Lawrence Erlbaum Associates.

Lowenberg, G. (1979). Interindividual consistencies in determining behavior-based dimensions of teaching effectiveness. Journal of Applied Psychology, 64, 492501.

Marks, H.M., \& Printy, S.M. (2003). Principal leadership and school performance: An integration of transformational and instructional leadership. Educational Administration Quarterly, 39(3), 370-97.

Marsh, J.A., Pane, J.F., \& Hamilton, L.S. (2006). Making sense of data-driven decision making in education. Santa Monica, CA: RAND Corporation.

Marshall, K. (1996). How I confronted HSPS (Hyperactive Superficial Principal 
Syndrome) and began to deal with the heart of the matter. Phi Delta Kappan, 76(5), 336-345.

Martone, A. \& Sireci, S.G. (2009). Evaluating alignment between curriculum, assessment, and instruction. Review of Educational Research, 79(4), 1332-1361. doi: 10.3102/0034654309341375.

Mawhinney, H. B., Frusicante, A. F., Aaron, P., \& Lui, Y. (2002). Design principles for learner centered schools: Building effective strategies for addressing the achievement gap. College Park, MD: Center for Education Policy and Leadership.

McGehee, J.J. \& Griffith, L.K. (2001). Large-scale assessments combined with curriculum alignment: Agents of change. Theory Into Practice, 40(2), 137-144.

Messelt, J. (2004). Data-driven decision making: A powerful tool for school improvement [White paper]. <https://www.erdc.k12.mn.us/promo/sage/images/Analytics_WhitePaper.pdf>.

Miles, M., \& Huberman, M. (1994). Qualitative data analysis: A sourcebook of new methods (2nd ed.). Newbury Park, CA: Sage.

Mortimore, P. (1993). School effectiveness and the management of effective learning and teaching. School Effectiveness and School Improvement, 4, 290-310.

Murphy, J., Hallinger, P., \& Mitman, A. (1983). Problems with research on educational leadership: Issues to be addressed. Educational Evaluation and Policy Analysis, 5(3), 297-306.

Murphy, J., \& Shipman, N. (2003). Developing standards for school leadership development: A process and rationale. In P. Hallinger (Ed.). Reshaping the landscape of school leadership development: A global perspective. Lisse, Netherlands: Swets \& Zeitlinger.

Mumford, M.D., \& Strange, J.M. (2005). The origins of vision: effects of reflection, models, and analysis. Leadership Quarterly, 16, 121-48.

Nelson, B.S., \& Sassi, A. (2005), The effective principal: Instructional leadership for high quality learning. New York: Teachers College Press.

Neumerski, C. (2012). Rethinking instructional leadership, a review: What do we know about principal, teacher, and coach instructional leadership, and where should we go from here? Educational Administration Quarterly, 49(2), 310-347. doi: 10.1177/0013161X12456700.

Niece, R. (1993). The principal as instructional leader: Past influences and current resources. NASSP Bulletin, 77(553), 12-18. 
Northouse, P. (2012). Leadership: Theory and Practice. (Sixth ed.). Los Angeles: SAGE Publishers.

Opie, N. (2004). Doing educational research. London: SAGE Publishers.

Patrick, J., Scrase, G., Ahmed, A., \& Tombs, M. (2009). Effectiveness of instructor behaviors and their relationship to leadership. Journal of Occupational and Organizational Psychology, 82, 491-509.

Parise, L.M. \& Spillane, J.P. (2010). Teacher learning and instructional change: How formal and on-the-job learning opportunities predict changes in elementary school teachers' practice. The Elementary School Journal, 110(3), 323-346. doi: $10.1086 / 648981$.

Pearce, C.L., \& Sims, H.P. (2001). Shared leadership: toward a multi-level theory of leadership. Advances in Interdisciplinary Studies of Work Teams, 7, 115-139.

Pink, D. H. (2009). Drive: The surprising truth about what motivates us. New York: Riverhead Books.

Pitner, N. (1988). The study of administrator effects and effectiveness. In N. Boyan (Ed.), Handbook of research in educational administration (pp. 106-132). New York: Longman.

Podsakoff, P., \& Organ, D. (1986). Self-reports in organizational research: Problems \& prospects. Journal of Management, 12, 86-94.

Priem, R.L., \& Rosenstein, J. (2000). Is organisation theory obvious to practitioners? A test of one established theory. Organisation Science, 11(5), 509-524.

Purkey, S., \& Smith, M. (1983). Effective schools: A review. The Elementary School Journal, 83(4), 426-452.

Quinn, D.M. (2002). The impact of principal leadership behaviors on instructional practice and student engagement. Journal of Educational Administration, 40(5), 447-467.

Reavis, C.A., Vinson, D., \& Fox, R. (1999). Importing a culture of success via a strong principal. Clearing House, 72(4), 199-202.

Ritchie, J. \& Lewis, J. (2003). Qualitative research practice: A guide for social science students and researchers. London: Sage.

Robinson, V. \& Lai, M. K. (2006). Practitioner research for educators: A guide to 
improving classrooms and schools. Thousand Oaks, Calif.: Corwin.

Robinson, V.M.J., Lloyd, C.A. \& Roww, K.J. (2008). The impact of leadership on student outcomes: an analysis of the differential effects of leadership types. Educational Administration Quarterly, 44, 635-674.

Rowe, W. G. (2001). Creating wealth in organizations: The role of strategic leadership. The Academy of Management Executive, 81-94.

Runhaar, P., Sanders, K., \& Yang, H. (2010). Stimulating teachers' reflection and feedback asking: An interplay of self-efficacy, learning goal orientation, and transformational leadership. Teaching and Teacher Education, 26(5), 1154-1161. doi: 10.1016/j.tate.2010.02.011

Rutter, Maugham, Mortimore, Ouston, \& Smith. (1979). Fifteen thousand hours: Secondary schools and their effects on children. Cambridge, Mass.: Harvard University Press.

Sala, F. (2003). Executive blind spots: Discrepancies between self- and other-ratings. Consulting Psychology Journal: Practice and Research, 55(4), 222-229. DOI 10.1037/1061-4087.55.4.222

Sala, F., \& Dwight, S. A. (2002). Predicting executive performance with multi-rater surveys: Whom you ask makes a difference. Consulting Psychology Journal: Practice and Research, 54, 166-172.

Schön, D. (1983). The reflective practitioner: How professionals think in action. London: Temple Smith.

Silva, J., White, G., \& Yoshida, R. (2011). The direct effects of principal-student discussions on eighth grade students' gains in reading achievement: An experimental study. Educational Administration Quarterly, 47, 772-793

Sims, H.P. Jr \& Lorenzi, P. (1992). The new leadership paradigm: Social learning and cognition in organisations. Newbury Park, CA: Sage Publishers.

Spillane, J. (2006). Distributed leadership. San Francisco: Jossey-Bass.

Smith, W., \& Andrews, R. (1989). Instructional leadership: How principals make a difference. Alexandria, Va.: Association for Supervision and Curriculum Development (ASCD) Press.

Stallings, J. (1980). Allocated academic learning time revisited, or beyond time on task. Educational Researcher, 9(11), 11-16. 
Stallings, J. \& Mohlman, G.G. (1981). School policy, leadership style, teacher change, and student behavior in eight schools. Mountain View, Calif.: Stallings Teaching and Learning Institute.

Strauss, A., \& Corbin, J. (1998). Basics of qualitative research: Techniques and procedures for developing grounded theory (2nd ed.). Thousand Oaks, CA: Sage Publication.

Stronge, J.H., \& Leeper, L.M. (2012). Research synthesis of Virginia principal evaluation competencies and standards. Richmond, VA: Virginia Department of Education.

Stronge, J.H., \& Tucker, P.D. (2003). Teacher evaluation: Assessing and improving performance. Larchmont, NY: Eye on Education

Supovitz, J. \& Sirinides, H. (2009). How principals and peers influence teaching and learning. Educational Administration Quarterly, 46, 31-56.

Tang, S. \& Chow, A. (2007). Communicating feedback in teaching practice supervision in a learning-oriented field experience assessment framework. Teaching and Teacher Education, 23, 1066-1085.

Timperley, H.S. \& Robinson, V.M.J. (1997). The problem of policy implementation: The case of performance appraisal. School Leadership and Management, 17, 333-345.

Tuytens, M. \& Devos, G. (2011). Stimulating professional learning through teacher evaluation: An impossible task for the school leader? Teaching and Teacher Education, 27, 891-899. doi: 10.1016/j.tate.2011.02.004.

Van Ryzin, M. J. (2011). Protective factors at school: Reciprocal effects among adolescents' perceptions of the school environment, engagement in learning, and hope. Journal of Youth and Adolescence, 40, 1568-1580. doi: 10.1007/s10964011-9637-7.

Van Velsor, E., Taylor, S., \& Leslie, J. B. (1993). An examination of the relationships among self-perception accuracy, selfawareness, gender, and leader effectiveness. Human Resource Management, 32(2-3), 249-263.

Virginia Code 22.1-294. (2011). Probationary terms of service for principals, assistant principals, and supervisors; evaluation; reassigning principal, assistant principal or supervisor to teaching position. Richmond, VA: Code of Virginia.

Virginia Department of Education. (2012). Guidelines for uniform performance standards and evaluation criteria for principals. Richmond, VA: Author.

Visser, P., Krosnick, J.A., \& Lavrakas, P.J. (2000). Survey research. In H.T. Reis \& C.M. 
Judd (Eds.), Handbook of research methods in social psychology. New York: Cambridge University Press.

Vollmeyer, R. \& Rheinberg, F. (2005). A surprising effect of feedback on learning. Learning and Instruction, 15, 589-602.

Witziers, B., Bosker, R., \& Kruger, M. (2003). Educational leadership and student achievement: The elusive search for an association. Educational Administration Quarterly, 34(3), 398-425.

Whitaker, B. (1997). Instructional leadership and principal visibility. Clearing House, 70(3), 155-157.

Wynne, E. (1980). Looking at schools: Good, bad, and indifferent. Lexington, Mass.: Lexington Books.

York-Barr, J., \& Duke, K. (2004). What do we know about teacher leadership? Findings from two decades of scholarship. Review of Educational Research, 74(3), 255316. 